Prepared in cooperation with the

City of Cambridge, Massachusetts, Water Department

\title{
Water-Quality Conditions, and Constituent Loads and Yields in the Cambridge Drinking-Water Source Area, Massachusetts, Water Years 2005-07
}

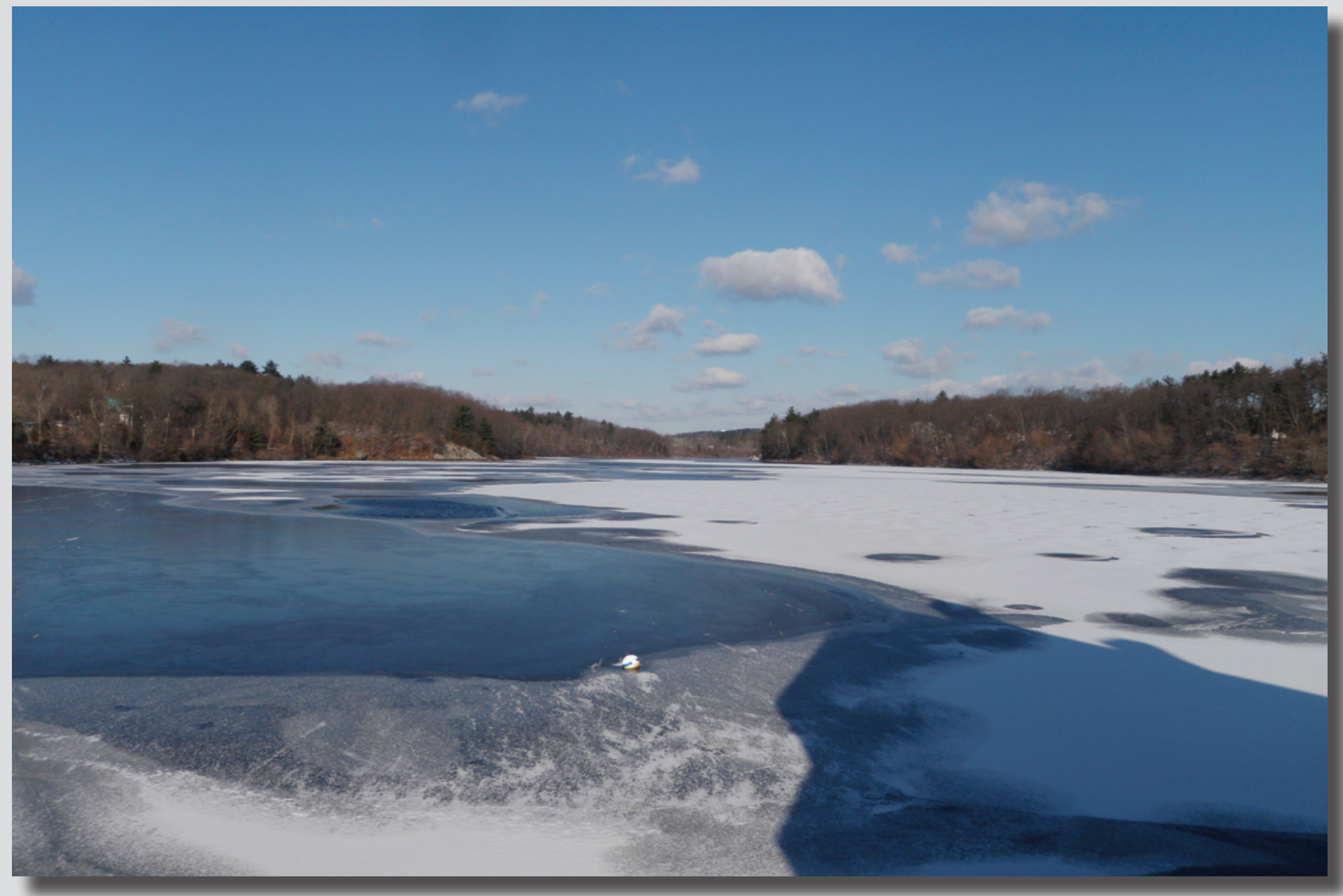

Scientific Investigations Report 2013-5039 
Cover. Photograph of Stony Brook Reservoir in Waltham, Massachusetts as taken from the gate house at the southern end of the reservoir by Joan Whitley, U.S. Geological Survey. 


\section{Water-Quality Conditions, and Constituent Loads and Yields in the Cambridge Drinking-Water Source Area, Massachusetts, Water Years 2005-07}

by Kirk P. Smith

Prepared in cooperation with the

City of Cambridge, Massachusetts, Water Department

Scientific Investigations Report 2013-5039 


\section{U.S. Department of the Interior \\ KEN SALAZAR, Secretary}

\section{U.S. Geological Survey \\ Suzette M. Kimball, Acting Director}

U.S. Geological Survey, Reston, Virginia: 2013

For more information on the USGS - the Federal source for science about the Earth, its natural and living resources, natural hazards, and the environment, visit http://www.usgs.gov or call 1-888-ASK-USGS.

For an overview of USGS information products, including maps, imagery, and publications, visit http://www.usgs.gov/pubprod

To order this and other USGS information products, visit http://store.usgs.gov

Any use of trade, firm, or product names is for descriptive purposes only and does not imply endorsement by the U.S. Government.

Although this information product, for the most part, is in the public domain, it also may contain copyrighted materials as noted in the text. Permission to reproduce copyrighted items must be secured from the copyright owner.

Suggested citation:

Smith, K.P., 2013, Water-quality conditions, and constituent loads and yields in the Cambridge drinking-water source area, Massachusetts, water years 2005-07: U.S. Geological Survey Scientific Investigations Report 2013-5039, 73 p., http://pubs.usgs.gov/sir/2013/5039/. 


\section{Acknowledgments}

The author wishes to thank Chip Norton, Watershed Manager, and David Kaplan, Watershed Protection Supervisor, Cambridge Water Department, for their help in planning and for facilitating this study. The author also wishes to thank Richard Zilinsky (retired), Jose Silva, and Robert

Bonvie of the Cambridge Water Department for their help with the installation of the monitoring shelters and access maintenance for each gage throughout the year. 
THIS PAGE INTENTIONALLY LEFT BLANK 


\section{Contents}

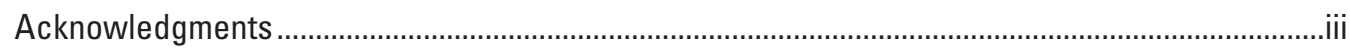

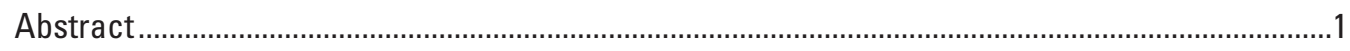

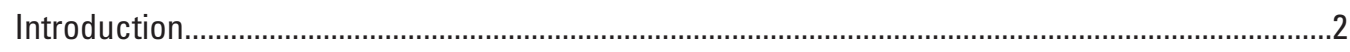

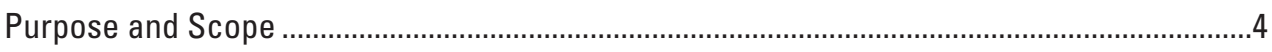

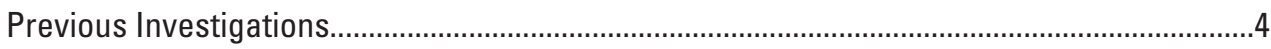

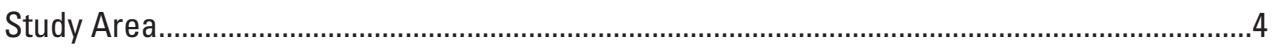

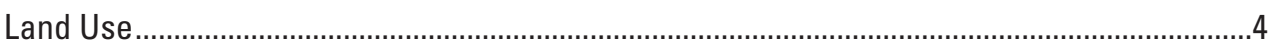

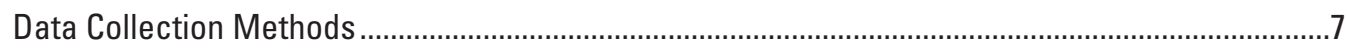

Continuous Monitoring of Streamflow and Water Quality......................................................

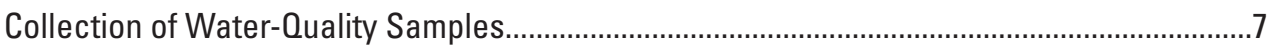

Quality-Assurance and Quality-Control Samples....................................................................10

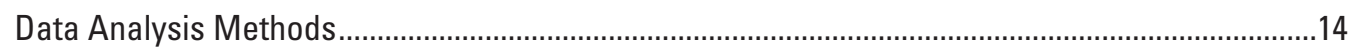

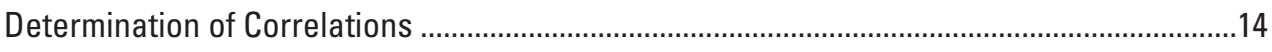

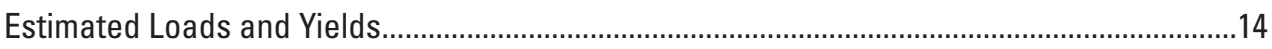

Loads Estimated from Streamflow........................................................................14

Loads of Major lons Estimated from Specific-Conductance Monitoring Data ...............16

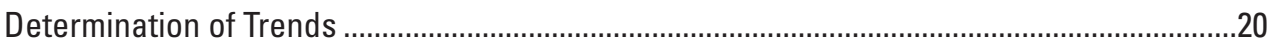

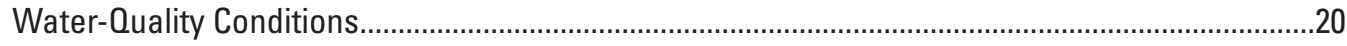

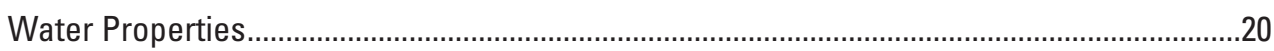

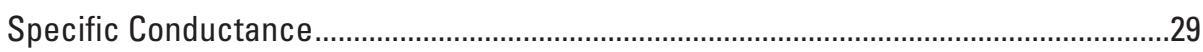

Dissolved Oxygen

$\mathrm{pH}$

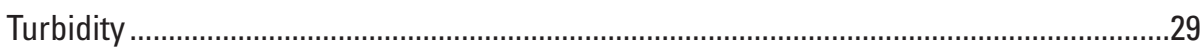

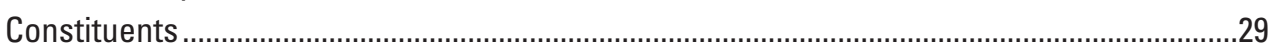

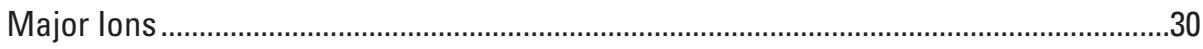

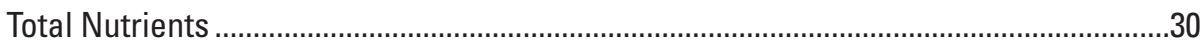

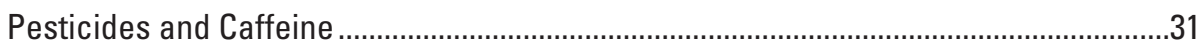

Factors Affecting Water-Quality Properties and Constituent Concentrations .........................39

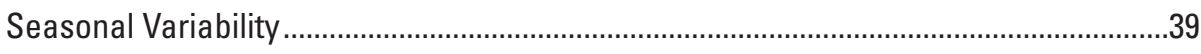

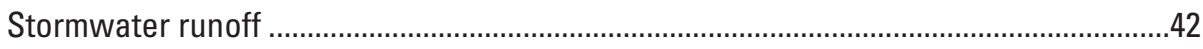

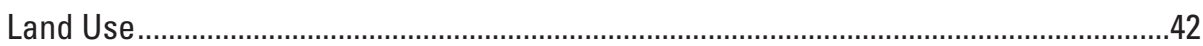

Comparison of Water-Quality Properties and Constituent Concentrations with WaterQuality Criteria and Guidelines .................................................................................4

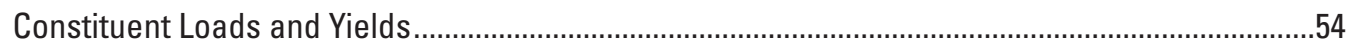

Loads and Yields of Calcium, Chloride, Sodium, and Sulfate, Water Years 1999 to 2008........54

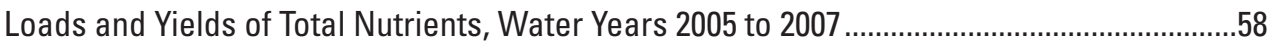

Loads and Yields of Selected Pesticides and Caffeine, Water Years 2005 to 2007..................63

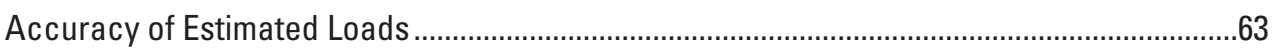

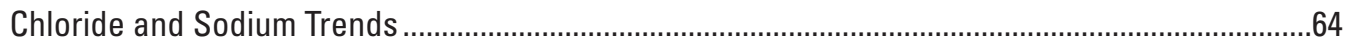

Summary

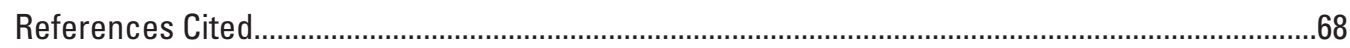




\section{Figures}

1. Map showing Cambridge drinking-water source area, Massachusetts.

2. Graph showing probability distribution of dry antecedent periods during water years 2005-07 for U.S. Geological Survey station 01104430 in the Cambridge Reservoir watershed, Massachusetts, in relation to the dry antecedent periods for storms where runoff samples were collected at U.S. Geological Survey station 01104415

3. Box plot showing distribution of precipitation totals greater than 0.10 inch recorded by the National Climatic Data Center near Boston, Massachusetts, 1967-2007; precipitation totals for all storms recorded at the Cambridge Reservoir during water years 2005-07; and precipitation totals for storms during which samples were collected at each of the primary sampling stations in the Cambridge drinking-water source area, Massachusetts, 2005-07.

4. Graph showing example of automated flow-proportional collection of stormflow subsamples at U.S. Geological Survey station 01104415, Cambridge drinking-water source area, Massachusetts, water year 2007

5. Graph showing relation of concentrations of selected constituents detected in concurrent replicate streamflow samples, Cambridge drinking-water source area, Massachusetts, water years 2005-07.

6. Box plots showing milliequivalent ratios of calcium, sodium, and sulfate to chloride in sample populations from six U.S. Geological Survey monitoring stations in the Cambridge drinking-water source area, Massachusetts, water years 2004-08.

7. Graph showing example of separation of base-flow and stormflow specific conductance at U.S. Geological Survey station 01104415, Cambridge drinking-water source area, Massachusetts, water year 2007.

8. Graph showing concentrations of selected pesticides and caffeine detected in samples of water collected during base flow and stormflow at all monitoring stations in the Cambridge drinking-water source area and from the Fresh Pond Reservoir raw-water intake, Cambridge, Massachusetts, water years 2004-08

9. Graphs showing records of flow and specific conductance during $A$, fall and $B$, winter storm runoff at U.S. Geological Survey station 01104455, Stony Brook Reservoir watershed, Massachusetts, water year 2007.

10. Box plots showing distributions of turbidity in base-flow and stormflow samples collected from five U.S. Geological Survey stations in the Cambridge drinking-water source area, Massachusetts, water years 2005-07

11. Box plots showing distributions of concentrations of $A$, dissolved calcium and $B$, chloride in base-flow and stormflow samples from five U.S. Geological Survey stations in the Cambridge drinking-water source area, Massachusetts, water years 2005-07.

12. Box plots showing distributions of concentrations of $A$, dissolved sodium and $B$, dissolved sulfate in base-flow and stormflow samples from five U.S. Geological Survey stations in the Cambridge drinking-water source area, Massachusetts, water years 2005-07.

13. Box plots showing distributions of concentrations of $A$, total nitrogen and $B$, total phosphorus in base-flow and stormflow samples from five U.S. Geological Survey stations in the Cambridge drinking-water source area, Massachusetts, water years 2005-07. 
14. Graph showing frequency of detection for selected pesticides in samples of base flow and stormflow collected at the primary sampling stations in the Cambridge

drinking-water source area, Massachusetts, water years 2005-07.

15. Graphs showing concentrations of calcium, chloride, sodium, sulfate, and caffeine in relation to the areal percentage of State maintained roads, town roads, and parking lots in 11 subbasins in the Cambridge drinking-water source area, Massachusetts, water years 2005-07

16. Graph showing probability distribution of daily specific conductance values during base flow and flow-weighted specific conductance values during runoff for U.S. Geological Survey station 01104415, Cambridge drinking-water source area, Massachusetts, in relation to estimated concentration values representing U.S. Environmental Protection Agency water-quality criteria for chloride, water years 2004-08

17. Graph showing probability distribution of daily specific conductance values during base flow and flow-weighted specific conductance values during runoff for U.S. Geological Survey station 01104433, Cambridge drinking-water source area, Massachusetts, in relation to estimated concentration values representing U.S. Environmental Protection Agency water-quality criteria for chloride, water years 2004-07

18. Graph showing probability distribution of daily specific conductance values during base flow and flow-weighted specific conductance values during runoff for U.S. Geological Survey station 01104455, Cambridge drinking-water source area, Massachusetts, in relation to estimated concentration values representing U.S. Environmental Protection Agency water-quality criteria for chloride, water years 2004-08

19. Graph showing probability distribution of daily specific conductance values during base flow and flow-weighted specific conductance values during runoff for U.S. Geological Survey station 01104475, Cambridge drinking-water source area, Massachusetts, in relation to estimated concentration values representing U.S. Environmental Protection Agency water-quality criteria for chloride, water years 2004-08.

20. Graphs showing relation of winter weather severity to annual sodium loads for U.S. Geological Survey stations A, 01104415, B, 01104455, and C, 01104475, Cambridge drinking-water source area, Massachusetts, water years 2004-08. 


\section{Tables}

1. Names, locations, drainage areas, and periods of record for U.S. Geological Survey monitoring and sampling stations in the Cambridge drinking-water source area, Massachusetts, water years 1997-2008

2. Areal percentages of land use for subbasins upstream from U.S. Geological Survey monitoring/sampling stations in Hobbs Brook and Stony Brook Basins, Massachusetts

3. Physical properties and constituents measured in water samples, respective long-term method detection limits, and analytical methods.....

4. Pearson correlation coefficients relating concentrations of major ions and total nutrients to streamflow at five U.S. Geological Survey monitoring/sampling stations in the Cambridge and Stony Brook Reservoir watersheds, Massachusetts, water years $2005-07$

5. Attained significance levels ( $p$ values) from Mann-Whitney tests for paired sample sets of concentrations of selected constituents and properties collected during base-flow and stormflow conditions in the Cambridge drinking-water source area, Massachusetts, water years 2005-07.

6. Regression equation coefficients used to estimate concentrations of calcium, chloride, sodium, and sulfate from flow-weighted values of specific conductance for U.S. Geological Survey monitoring/sampling stations in the Cambridge drinking-water source area, Massachusetts, water years 2005-07.

7. Summary statistics for selected water-quality properties, major ions, total nutrients, caffeine, and pesticides in samples of base flow and stormflow collected at five primary sampling stations in the Cambridge drinking-water source area and at the raw water intake at Fresh Pond Reservoir, Cambridge, Massachusetts, water years 2005-07.

8. Summary statistics for selected water-quality properties, major ions, total nutrients, caffeine, and pesticides in samples of base flow collected during three synoptic sampling rounds at the secondary sampling stations in the Cambridge drinking-water source area, Massachusetts, water years 2006-07.

9. Characteristics of pesticides detected in samples of base flow and stormflow collected in the Hobbs Brook and Stony Brook Reservoir watersheds, Massachusetts, water years 2005-07.

10. Frequency of detection, standards for drinking water and aquatic life, and maximum concentrations of selected pesticides in water samples collected in Hobbs Brook Basin and Stony Brook Reservoir watershed and in samples of raw water collected from the intake of the water-treatment facility at Fresh Pond, Massachusetts, water years 2005-07.

11. Pearson correlation coefficients relating percentage of land-use classes to annual flow-weighted concentrations of selected major ions, total nutrients, caffeine, and selected pesticides for four subbasins in the Cambridge and Stony Brook Reservoir watersheds, Massachusetts, 2005-07

12. Pearson correlation coefficients relating percentage of land-use classes to mean concentrations of selected major ions and total nutrients in base flow and maxiumum concentrations of caffeine and selected pesticides in base flow in the subbasins of the primary and secondary sampling stations in the Cambridge and Stony Brook Reservoir watersheds, Massachusetts, water years 2006-07 
13. Mean concentrations and confidence intervals for selected major ions, total nutrients, pesticides, and caffeine in samples of streamwater collected at five primary sampling stations in the Cambridge drinking-water source area,

Massachusetts, water years 2005-07.

14. Annual loads and yields of calcium, chloride, sodium, sulfate, total nutrients, caffeine, and 11 pesticides for 5 primary sampling stations in the Cambridge and Stony Brook Reservoir watersheds, Massachusetts, water years 2005-07.

15. Annual mean flow, runoff, and estimated annual loads of calcium, chloride, sodium, and sulfate for sampling stations in the Cambridge and Stony Brook Reservoir watersheds, Massachusetts, water years 1999-2008... 


\section{Conversion Factors and Datum}

\begin{tabular}{|c|c|c|}
\hline Multiply & By & To obtain \\
\hline \multicolumn{3}{|c|}{ Length } \\
\hline foot $(\mathrm{ft})$ & 0.3048 & meter $(\mathrm{m})$ \\
\hline mile (mi) & 1.609 & kilometer $(\mathrm{km})$ \\
\hline \multicolumn{3}{|c|}{ Area } \\
\hline Acre & 0.004047 & square kilometer $\left(\mathrm{km}^{2}\right)$ \\
\hline square mile $\left(\mathrm{mi}^{2}\right)$ & 2.590 & square kilometer $\left(\mathrm{km}^{2}\right)$ \\
\hline \multicolumn{3}{|c|}{ Volume } \\
\hline gallon (gal) & 3.785 & liter (L) \\
\hline cubic inch $\left(\mathrm{in}^{3}\right)$ & 0.01639 & liter (L) \\
\hline cubic foot $\left(\mathrm{ft}^{3}\right)$ & 0.02832 & cubic meter $\left(\mathrm{m}^{3}\right)$ \\
\hline \multicolumn{3}{|c|}{ Flow rate } \\
\hline cubic foot per second $\left(\mathrm{ft}^{3} / \mathrm{s}\right)$ & 0.02832 & cubic meter per second $\left(\mathrm{m}^{3} / \mathrm{s}\right)$ \\
\hline \multicolumn{3}{|c|}{ Mass } \\
\hline ounce, avoirdupois (oz) & 28.35 & $\operatorname{gram}(\mathrm{g})$ \\
\hline pound, avoirdupois (lb) & 0.4536 & kilogram (kg) \\
\hline ton, short $(2,000 \mathrm{lb})$ & 0.9072 & metric ton (MT) \\
\hline
\end{tabular}

Temperature in degrees Celsius $\left({ }^{\circ} \mathrm{C}\right)$ may be converted to degrees Fahrenheit $\left({ }^{\circ} \mathrm{F}\right)$ as follows:

${ }^{\circ} \mathrm{F}=\left(1.8 \times^{\circ} \mathrm{C}\right)+32$

Vertical coordinate information is referenced to North American Vertical Datum of 1988 (NAVD 88).

Horizontal coordinate information is referenced to the North American Datum of 1983 (NAD 83).

Altitude, as used in this report, refers to distance above the vertical datum.

Specific conductance is given in microsiemens per centimeter at 25 degrees Celsius $(\mu \mathrm{S} / \mathrm{cm}$ at $\left.25^{\circ} \mathrm{C}\right)$.

Concentrations of chemical constituents in water are given either in milligrams per liter (mg/L) or micrograms per liter ( $\mu \mathrm{g} / \mathrm{L})$.

\section{Abbreviations}

$\begin{array}{ll}\text { ASTM } & \text { American Society for Testing and Materials } \\ \text { COV } & \text { coefficient of variation } \\ \text { CCC } & \text { criterion continuous concentration } \\ \text { CMC } & \text { criterion maximum concentration } \\ \text { CWD } & \text { city of Cambridge, Massachusetts, Water Department } \\ \text { DWRL } & \text { drinking-water lifetime exposure level } \\ \text { HPLC } & \text { high-performance liquid chromatography } \\ \text { ISO } & \text { International Organization for Standardization } \\ \text { MCL } & \text { Maximum Contaminant Level }\end{array}$




$\begin{array}{ll}\text { NIST } & \text { National Institute of Standards and Technology } \\ \text { NWOL } & \text { National Water Quality Laboratory } \\ \text { NTRU } & \text { nephelometric turbidity ratio units } \\ \text { NTU } & \text { nephelometric turbidity units } \\ p & \text { attained significance level } \\ \text { RPD } & \text { relative percent difference } \\ \text { SDWR } & \text { Secondary Drinking-Water Regulation } \\ \text { USEPA } & \text { U.S. Environmental Protection Agency } \\ \text { USGS } & \text { U.S. Geological Survey } \\ \text { WWSI } & \text { winter weather severity index }\end{array}$


THIS PAGE INTENTIONALLY LEFT BLANK 


\title{
Water-Quality Conditions, and Constituent Loads and Yields in the Cambridge Drinking-Water Source Area, Massachusetts, Water Years 2005-07
}

\author{
By Kirk P. Smith
}

\section{Abstract}

The source water area for the drinking-water supply of the city of Cambridge, Massachusetts, encompasses major transportation corridors, as well as large areas of light industrial, commercial, and residential land use. Because of ongoing development in the drinking-water source area, the Cambridge water supply has the potential to be affected by a wide variety of contaminants. The U.S. Geological Survey (USGS) has monitored surface-water quality in the Hobbs Brook and Stony Brook Basins, which compose the drinking-water source area, since 1997 (water year 1997) through continuous monitoring and discrete sample collection and, since 2004, through systematic collection of streamwater samples during base-flow and stormflow conditions at five primary sampling stations in the drinking-water source area. Four primary sampling stations are on small tributaries in the Hobbs Brook and Stony Brook Basins; the fifth primary sampling station is on the main stem of Stony Brook and drains about 93 percent of the Cambridge drinking-water source area. Water samples also were collected at six secondary sampling stations, including Fresh Pond Reservoir, the final storage reservoir for the raw water supply. Storm runoff and base-flow concentrations of calcium $(\mathrm{Ca})$, chloride $(\mathrm{Cl})$, sodium $(\mathrm{Na})$, and sulfate $\left(\mathrm{SO}_{4}\right)$ were estimated from continuous records of streamflow and specific conductance for six monitoring stations, which include the five primary sampling stations. These data were used to characterize current water-quality conditions, estimate loads and yields, and describe trends in $\mathrm{Cl}$ and $\mathrm{Na}$ in the tributaries and main-stem streams in the Hobbs Brook and Stony Brook Basins. These data also were used to describe how streamwater quality is affected by various watershed characteristics and provide information to guide future watershed management.

Water samples were analyzed for physical properties and concentrations of $\mathrm{Ca}, \mathrm{Cl}, \mathrm{Na}$, and $\mathrm{SO}_{4}$, total nitrogen (TN), total phosphorus (TP), caffeine, and a suite of 59 polar pesticides. Values of physical properties and constituent concentrations varied widely, particularly in samples from tributaries. Median concentrations of $\mathrm{Ca}, \mathrm{Cl}, \mathrm{Na}$, and $\mathrm{SO}_{4}$ in samples collected in the Hobbs Brook Basin (39.8, 392, 207, and 21.7 milligrams per liter ( $\mathrm{mg} / \mathrm{L})$, respectively) were higher than those for the Stony Brook Basin (17.8, 87.7, 49.7, and $14.7 \mathrm{mg} / \mathrm{L}$, respectively). These differences in major ion concentrations are likely related to the low percentages of developed land and impervious area in the Stony Brook Basin. Concentrations of dissolved $\mathrm{Cl}$ and $\mathrm{Na}$ in samples, and those estimated from continuous records of specific conductance (particularly during base flow), often were greater than the U.S. Environmental Protection Agency (USEPA) secondary drinking-water guideline for $\mathrm{Cl}(250 \mathrm{mg} / \mathrm{L})$, the chronic aquatic-life guideline for $\mathrm{Cl}(230 \mathrm{mg} / \mathrm{L})$, and the Commonwealth of Massachusetts, Executive Office of Energy and Environmental Affairs drinking-water guideline for $\mathrm{Na}$ $(20 \mathrm{mg} / \mathrm{L})$. Mean annual flow-weighted concentrations of $\mathrm{Ca}$, $\mathrm{Cl}$, and $\mathrm{Na}$ were generally positively correlated with the area of roadway land use in the subbasins. Correlations between mean annual concentrations of $\mathrm{Ca}$ and $\mathrm{SO}_{4}$ in base flow and total roadway, total impervious, and commercial-industrial land uses were statistically significant.

Concentrations of TN (range of 0.42 to $5.13 \mathrm{mg} / \mathrm{L}$ in all subbasins) and TP (range of 0.006 to $0.80 \mathrm{mg} / \mathrm{L}$ in all subbasins) in tributary samples did not differ substantially between the Hobbs Brook and Stony Brook Basins. Concentrations of TN and TP in samples collected during water years 2004-07 exceeded proposed reference concentrations of 0.57 and $0.024 \mathrm{mg} / \mathrm{L}$, in 94 and 56 percent of the samples, respectively. Correlations between annual flow-weighted concentrations of $\mathrm{TN}$ and percentages of recreational land use and water-body area were statistically significant; however, no significant relation was found between TP and available land-use information. The volume of streamflow affected water-quality conditions at the primary sampling stations. Turbidity and concentrations of TP were positively correlated with streamflow. In contrast, concentrations of major ions were negatively correlated with streamflow, indicating that these constituents were diluted during stormflows. Concentrations of TN were not correlated with streamflow.

Twenty-five pesticides and caffeine were detected in water samples collected in the drinking-water source area and 
in raw water collected from the Cambridge water-treatment facility intake at the Fresh Pond Reservoir. Imidacloprid, norflurazon, and siduron were the most frequently detected pesticides with the frequency of detections ranging from about 24 to 41 percent. Caffeine was detected in about 64 percent of water samples at concentrations ranging from 0.003 to 1.82 micrograms per liter $(\mu \mathrm{g} / \mathrm{L})$. Although some of the detected pesticides degrade rapidly, norflurazon and siduron are relatively stable and are able to immigrate though the serial reservoir system. Concentrations of 2,4-D, carbaryl, imazaquin, MCPA (2-methyl-4-chlorophenoxyacetic acid), metsulfuron-methyl, norflurazon, siduron, and caffeine were detected more frequently in stormflow samples than in baseflow samples. Concentrations of pesticides did not exceed USEPA drinking-water guidelines or other health standards and were several orders of magnitude less than the lethal exposure level established for several fish species common to the drinking-water source area. Imidacloprid, an insecticide, was the only pesticide with a concentration exceeding available long-term aquatic-life guidelines. Several pesticides correlated significantly with the amount of recreational, residential, and commercial area in the tributary subbasins. Mean annual baseflow concentrations of caffeine correlated significantly with parking-lot land use.

For most tributaries, about 70 percent of the annual loads of $\mathrm{Ca}, \mathrm{Cl}, \mathrm{Na}$, and $\mathrm{SO}_{4}$ were associated with base flow. Upward temporal trends in annual loads of $\mathrm{Cl}$ and $\mathrm{Na}$ were identified on the basis of data for water years 1998 to 2008 for the outlet of the Cambridge Reservoir in the Hobbs Brook Basin; however, similar trends were not identified for the main stem of Stony Brook downstream from the reservoir. The proportions of the TN load attributed to base flow and stormflow were similar in each tributary. In contrast, more than 83 percent of the TP loads in the tributaries and about 73 percent of the TP load in main stem of Stony Brook were associated with stormflow.

Mean annual yields of $\mathrm{Ca}, \mathrm{Cl}, \mathrm{Na}$, and $\mathrm{SO}_{4}$ in the Stony Brook Reservoir watershed, which represents most of the drinking-water source area, were 14, 85, 46, and 9 metric tons per square kilometer, respectively. Mean annual yields among the individual tributary subbasins varied extensively. Mean annual yields for the respective constituents increased with an increase in roadway and parking-lot area in the tributary subbasins. Mean annual yields of TN in the tributary subbasins ranged from about 740 to more than 1,200 kilograms per square kilometer and exceeded the yield for the main stem of Stony Brook at USGS station 01104460 upstream from the Stony Brook Reservoir.

Mean annual yields estimated for the herbicides 2,4-D and imidacloprid ranged from 34 to 310 grams per square kilometer $\left(\mathrm{g} / \mathrm{km}^{2}\right)$ and 3 to $170 \mathrm{~g} / \mathrm{km}^{2}$, respectively. Annual loads for 2,4-D were entirely associated with stormflow. The largest annual load for imidacloprid was estimated for the main stem of Stony Brook; however, the highest annual yield for this pesticide, as well as for benomyl, carbaryl, metalaxyl, and propiconazole, was estimated for a tributary to the Stony
Brook Reservoir that drains largely residential and recreational areas. Mean annual yields for the herbicide siduron ranged from 6.9 to $35 \mathrm{~g} / \mathrm{km}^{2}$ with most of the loads associated with stormflow. Mean annual yields for the insecticide diuron ranged from 2.1 to $4.4 \mathrm{~g} / \mathrm{km}^{2}$. Annual yields of caffeine ranged from 11 to $410 \mathrm{~g} / \mathrm{km}^{2}$.

\section{Introduction}

The city of Cambridge, Massachusetts supplies approximately 15 million gallons per day (Waldron and Bent, 2001) of drinking water to more than 100,000 customers. The Cambridge Water Department (CWD) obtains raw water from a serial system of three primary storage reservoirs. These reservoirs receive inflow from a drainage area of 61.4 square kilometers $\left(\mathrm{km}^{2}\right)$ (henceforth, the drinking-water source area) that is outside Cambridge; in parts of the towns of Lexington, Lincoln, and Weston; and in part of the city of Waltham (fig. 1). Only about 5 percent of the land in the drinking-water source area is owned by the city of Cambridge. Major transportation corridors (Interstate 95, Routes 2, 2A, 20, and 117), as well as large areas of industrial, commercial, and residential land use, are within the drinking-water source area.

Effective management of the drinking-water source area requires an understanding of how streamwater quality is affected by natural and cultural watershed factors. Drought and severe weather are examples of natural factors, whereas the amount of impervious area and application of pesticides are cultural factors. Because of the diverse land use within the drinking-water source area, there is a large number of constituents with varied transport mechanisms that could potentially enter the drinking-water supply.

In 1997, the U.S. Geological Survey (USGS), in cooperation with the CWD, began operation of continuous waterquality monitoring stations (streamflow, water temperature, and specific conductance) at various locations in the drinking-water source area (Smith, 2005, 2007, 2008, and 2011; Socolow and others, 1999, 2000, 2001, 2002, 2003, and 2004; U.S. Geological Survey, 2009). In 2004, the USGS, in cooperation with the CWD, established a program to characterize water quality during base-flow and storm-runoff conditions in four tributaries to the Cambridge and Stony Brook Reservoirs and in the main stem of Stony Brook, the primary source of inflow to the Stony Brook Reservoir. These primary sampling stations were identified by Waldron and Bent (2001) and by the CWD as draining areas that are potentially important sources of contaminants. Monitoring data can be used to characterize current water-quality conditions, to establish a baseline for future comparisons, and if sufficient data are available, to describe trends in surface-water quality. These data also can be used to assess the effects of various watershed characteristics on surface-water quality and to provide information to guide future watershed management. 

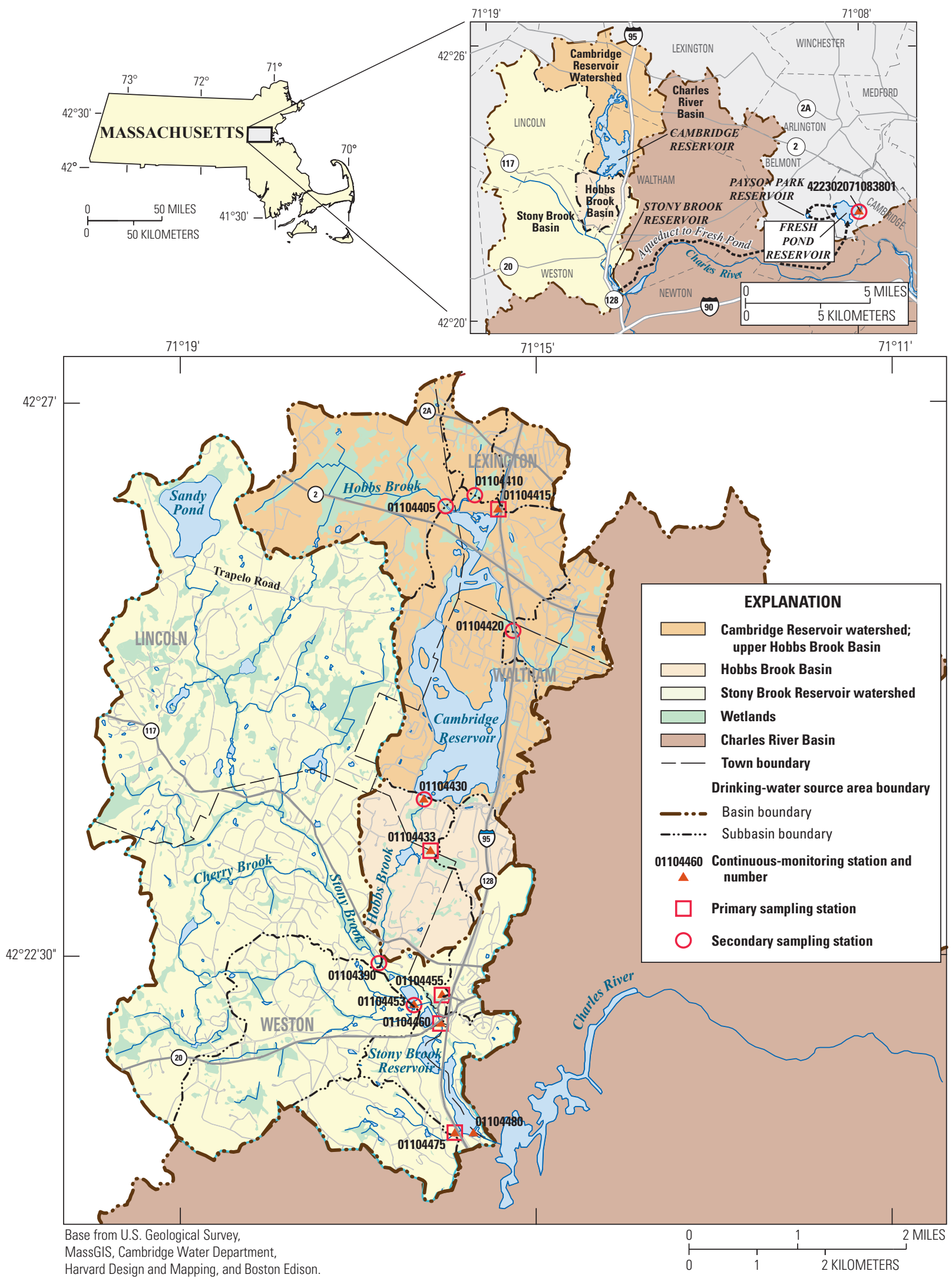

Figure 1. Cambridge drinking-water source area, Massachusetts. 


\section{Purpose and Scope}

The purpose of this report is to describe water-quality conditions in the drinking-water source area for the city of Cambridge during water years ${ }^{1} 2005-07$. Loads and yields of selected major ions, total nutrients, polar pesticides, and caffeine were estimated from water samples collected during periods of base flow and stormwater runoff from the main stem of Stony Brook and four tributaries within the drinkingwater source area. Most samples were collected during water years 2005-07. Four stations were sampled on one occasion at the end of water year 2004, and USGS station 01104475 was sampled on one occasion at the beginning of water year 2008. The relations between constituent yields and land-use characteristics are discussed. Estimates of annual loads and yields of selected major ions for water years 1999 to 2008 at several USGS monitoring stations determined using continuous records of flow and mathematical relations between specific conductance and concentrations are presented. Finally, temporal trends in annual mean loads of chloride $(\mathrm{Cl})$ and sodium (Na) analyzed for water years 1998 to 2008 for USGS stations 01104430 (Hobbs Brook at the outlet of Cambridge Reservoir) and 01104460 (main stem of Stony Brook) are discussed.

\section{Previous Investigations}

Since 1997, hydrologic and water-quality data were collected for various periods for tributaries in the Hobbs Brook and Stony Brook Basins (table 1). Waldron and Bent (2001) assessed limnological conditions in the three serial storage reservoirs and described the water-quality conditions in the drinking-water source area during 1997-98. They also identified sources of various constituents, including calcium (Ca), $\mathrm{Cl}$, Na, sulfate $\left(\mathrm{SO}_{4}\right)$, total nitrogen (TN), and total phosphorus (TP), in the drinking-water source area and outlined a sourcewater protection program for the CWD. Subsequently the USGS, in cooperation with the CWD, designed and implemented a monitoring network in the drinking-water source area (table 1). Streamflow, water-quality, and meteorological data from this network are available to the public online through the USGS Massachusetts-Rhode Island Water Science Center on the World Wide Web page (http://ma.water.usgs. gov) and in various reports (Smith, 2005, 2007, 2008, and 2011; Socolow and others, 1999, 2000, 2001, 2002, 2003, and 2004; U.S. Geological Survey, 2009).

\section{Study Area}

The drinking-water supply area includes three serial storage reservoirs - Cambridge Reservoir (also known as the Hobbs Brook Reservoir), Stony Brook Reservoir, and Fresh

\footnotetext{
${ }^{1} \mathrm{~A}$ water year is the 12-month period beginning on October 1 and ending September 30 of the following year. The water year is designated by the year in which it ends.
}

Pond Reservoir (fig. 1). The Cambridge Reservoir watershed includes Hobbs Brook and three unnamed tributaries that flow directly into the reservoir. Water is released from the southern end of the Cambridge Reservoir into Hobbs Brook, which receives additional inflow from an unnamed tributary about $0.8 \mathrm{~km}$ (kilometers) downstream from the reservoir. The confluence of Hobbs Brook and Stony Brook is about $2.6 \mathrm{~km}$ downstream from the Cambridge Reservoir. The area above this confluence is herein referred to as the "Hobbs Brook Basin" and includes the drainage area of the Cambridge Reservoir. Two unnamed tributaries flow into Stony Brook about $0.4 \mathrm{~km}$ north of the Stony Brook Reservoir. In addition to Stony Brook, an unnamed tributary flows directly into the Stony Brook Reservoir on the southwestern side of the reservoir. Additional water enters both reservoirs from other minor tributaries and storm drains. Water from Stony Brook Reservoir is piped through an aqueduct directly to Fresh Pond Reservoir, which is within the city of Cambridge about $16 \mathrm{~km}$ east of the drinking-water source area, where it is stored prior to treatment. Overflow and controlled releases from the Stony Brook Reservoir flow into the Charles River. Fresh Pond Reservoir is a glacial kettle lake with minimal surface-water inflow. The water level in Fresh Pond Reservoir is generally maintained above normal groundwater levels, thereby, limiting groundwater inflow to about 3 percent of the daily water demand (City of Cambridge, 2011).

\section{Land Use}

Land-use data were obtained, in part, from the Office of Geographic Information (MassGIS, 2002) and the Geographic Information System (GIS) developed by the CWD with data from MassGIS, the USGS National Mapping Division, Harvard Design and Mapping, and Boston Edison. In an effort to better characterize various land-use data, the areal coverages of commercial landscaped areas, parking lots, and roof tops were estimated from orthophotographs (MassGIS, 2005). The areas occupied by these land-use classes were subtracted from the more generalized land-use categories so that the aggregate of all areal coverages for each subbasin was 100 percent. For example, roadways, roofs, parking lots, sidewalks, and recreational areas that were within residential areas were not included in the residential category. As a result, the remaining residential land-use areas include only yards and wooded areas (otherwise not designated as forest) between house lots. Similarly, roadways, roofs, parking lots, sidewalks, or areas identified as landscaped were excluded from commercial land-use area calculations. Land-use data for each subbasin are listed in table 2.

Land uses in the Hobbs Brook and the Stony Brook Basins are similar. In general, these suburban basins are largely residential with relatively low percentages of commercial and light-industrial development. State and Interstate highways traverse each basin, and the percentages of forest and wetland areas are similar (about 32 and 11 percent, 


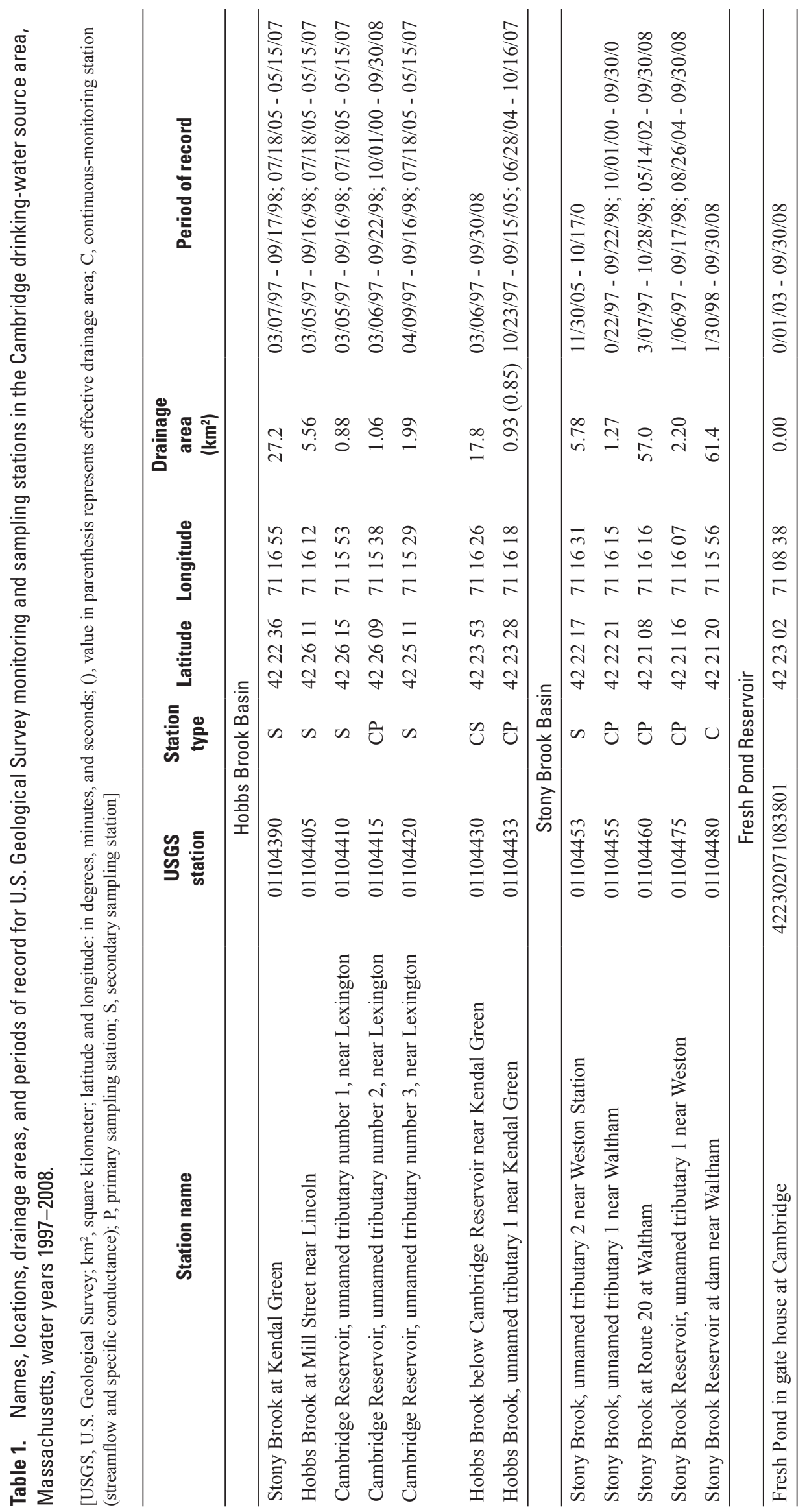




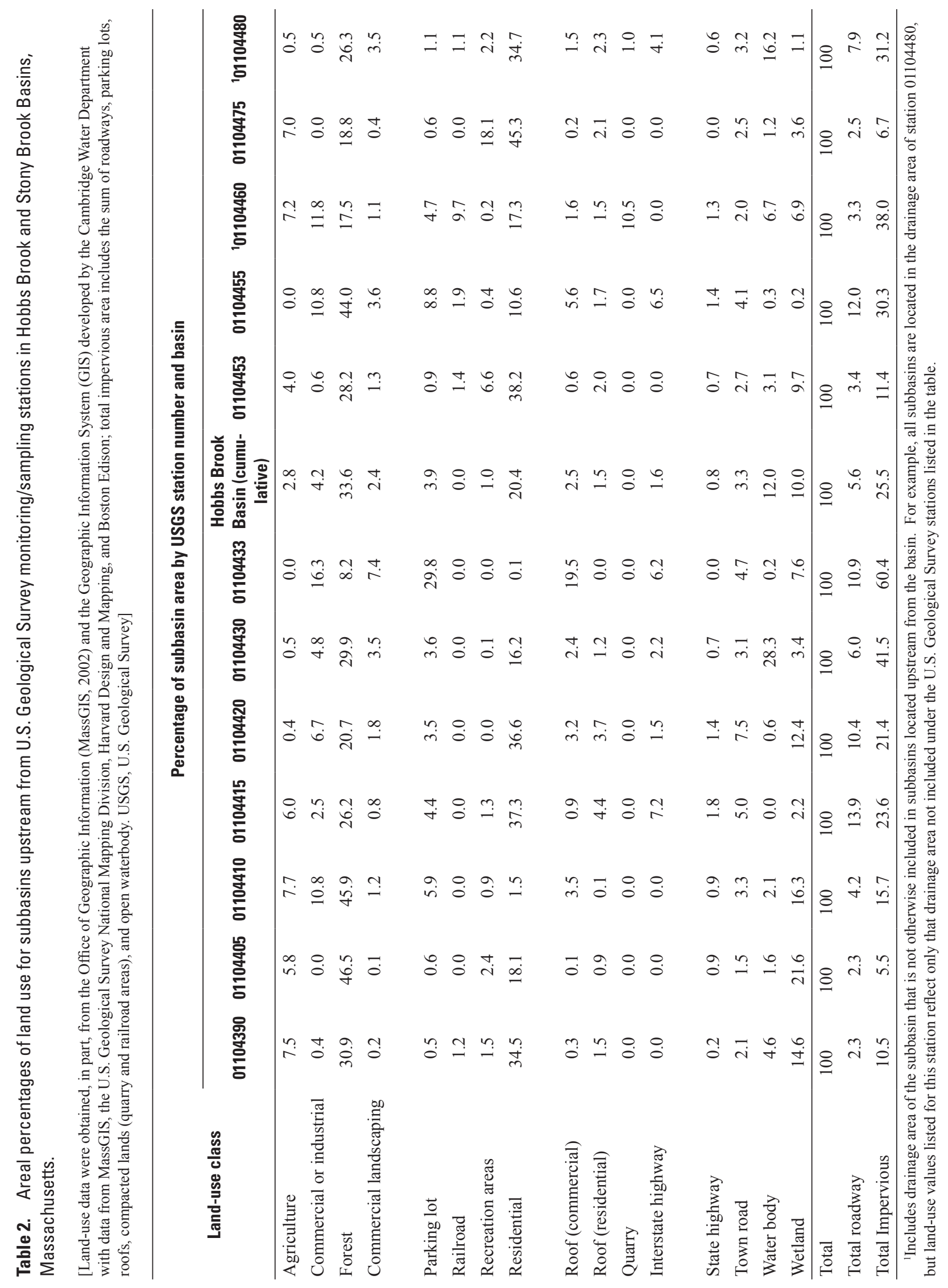


respectively). However, the amount of impervious area, including roadways, parking lots, and roofs, and the area of open water, differs between the two basins. The Hobbs Brook Basin contains about twice as much impervious area and nearly three times as much open water as the Stony Brook Basin (table 2).

\section{Data Collection Methods}

The monitoring network for the Cambridge drinkingwater source area includes seven USGS stations in the Hobbs Brook Basin and five USGS stations in the Stony Brook Reservoir watershed (fig. 1). During 2004-08, three continuous-monitoring stations (USGS stations 01104415, 01104430, and 01104433) were operating in the Hobbs Brook Basin, and five additional monitoring stations were operating in the Stony Brook Reservoir watershed (USGS stations 01104455, 01104453, 01104460, 01104475 and 01104480). Continuous measurements of water levels, used to estimate streamflow, water temperature, and specific conductance, were recorded at each continuous-monitoring station. During the present study, the USGS collected water samples during base-flow conditions and during rain and mixed-precipitation stormflow conditions at five primary sampling stations in the Hobbs Brook and Stony Brook Basins. Four of these primary sampling stations are on tributaries (USGS stations 01104415 , 01104433, 01104455, and 01104475), and one station is on the main stem of Stony Brook (USGS station 01104460; fig. 1) upstream from the Stony Brook Reservoir. The samples were collected primarily during water years 2005-07. Additional water samples were collected at the secondary sampling stations (fig.1) during base-flow conditions. Continuous streamflow records and measurements of the central tendency for constituent concentrations were used to estimate loads and yields of major ions, TN and TP, selected pesticides, and caffeine for water years 2005 to 2007. Finally, loads and yields of major ions also were estimated for streamflow at continuousmonitoring stations using available records of streamflow and constituent concentrations estimated from records of specific conductance.

\section{Continuous Monitoring of Streamflow and Water Quality}

Streamflow data are necessary to estimate constituent loads and yields in each subbasin or watershed. At each continuous-monitoring station, stream stage is recorded at a minimum interval of 10 minutes. Streamflow at each station is computed with a stage-discharge relation (or rating), which is developed and maintained on the basis of periodic manual measurements of streamflow (Rantz and others, 1982). Continuous water-temperature and specific-conductance data are recorded concurrently with stage by water-quality monitors at each continuous-monitoring station. Although measurements of water temperature and specific conductance are generally robust, the sensors are subject to fouling from aquatic growth, sedimentation, and debris. In such cases, corrections are applied to the data to improve accuracy as described by Wagner and others (2006a). More detailed descriptions of the monitoring network are provided by Smith (2005, 2007, 2008, and 2011).

\section{Collection of Water-Quality Samples}

Water samples were collected from streams in all the subbasins in the drinking-water source area and from the rawwater intake to the treatment plant at Fresh Pond Reservoir during the study period (water years 2005-07); as previously mentioned, a few samples also were collected in water years 2004 and 2008. At most primary sampling stations (table 1), 15 water samples were collected manually during base-flow conditions, and 15 composite samples were collected with automatic samplers during stormflow conditions. Only 12 samples of base-flow water and 12 composite samples of storm runoff were collected at USGS station 01104460 on the main stem of Stony Brook. Water samples also were collected at secondary sampling stations (USGS stations 01104390 , 01104405, 01104410, 01104420, 01104430, and 01104453) during three synchronous sampling rounds (Smith 2008, 2011) when samples of base flow were collected at primary sampling stations.

Samples of base flow were collected throughout the year to reflect seasonal variations. Water samples were collected manually using standard USGS techniques (Wilde and others, 1999) during base-flow conditions preceded by a dry period of at least 3 days. Stormflow sampling periods were selected to reflect seasonal variation and variation in the length of antecedent dry conditions existing throughout the study period (fig. 2). In this study, storms are defined, in terms of wet precipitation, as events with one or more measurements of wet precipitation equal to or greater than 0.01 inch (in.; the minimum resolution of the rain gage) and preceded by a dry period of at least 6 hours. Most of the storms sampled during this study were within the interquartile range (between the 25 th and 75 th percentiles) of precipitation totals greater than 0.10 in. recorded from 1967 through 2007 by the National Climatic Data Center near Boston, Mass. (Granato, 2007, fig. 3), as well as the interquartile range of all storm volumes greater than 0.10 in. recorded at the Cambridge Reservoir (USGS station 01104430) during the study period.

Stormflow samples were collected with automatic samplers controlled by a datalogger (Smith 2008, 2011). The first subsample was collected when flow exceeded a flow threshold that was marginally greater than pre-storm base flow, and subsequent subsamples were collected at flow-proportional intervals (fig. 4). Collection of subsamples continued throughout the flow recession following the peak flow. The length of the recession period was calculated on the basis of the size of 


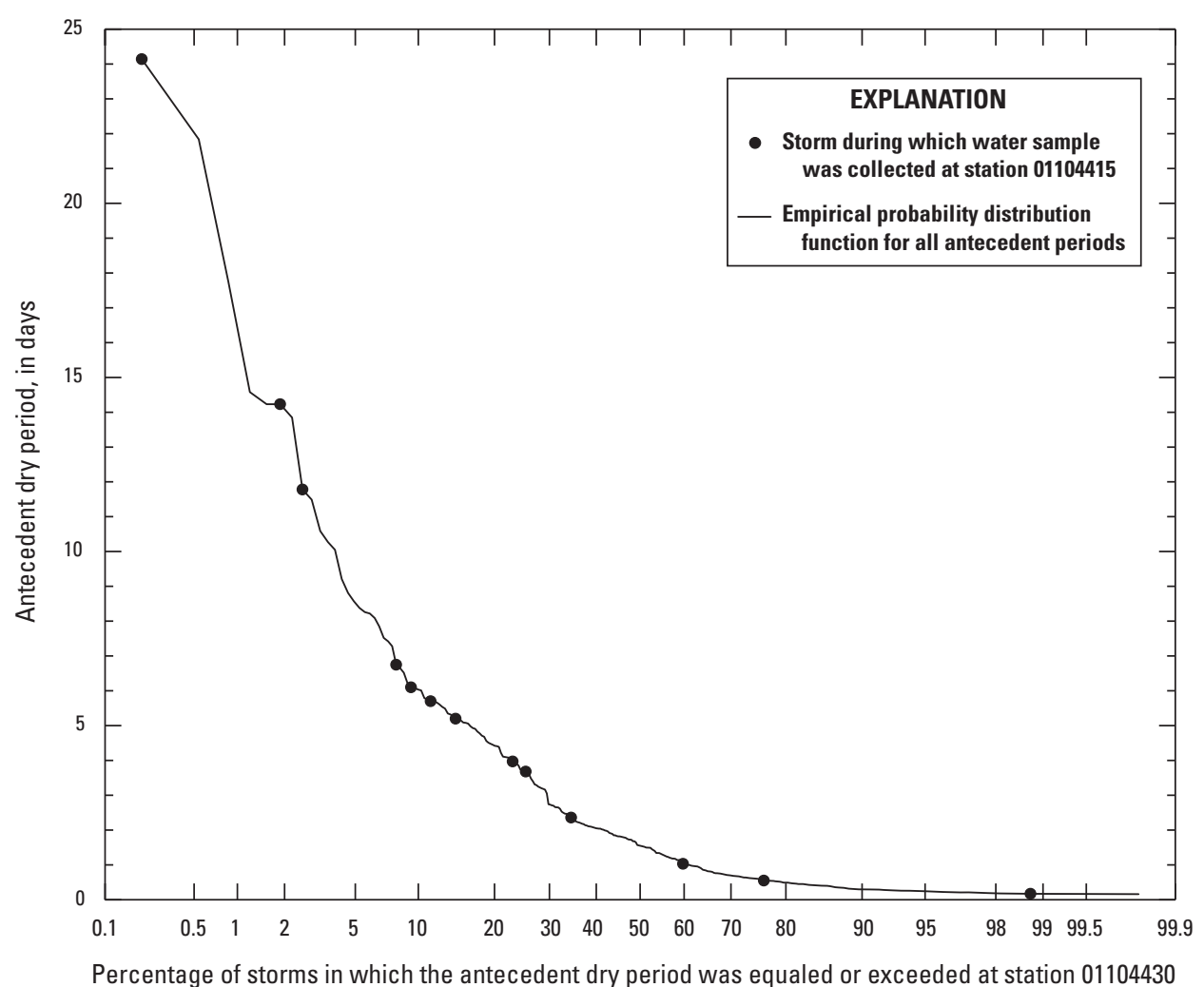

Figure 2. Probability distribution of dry antecedent periods during water years 2005-07 for U.S. Geological Survey station 01104430 in the Cambridge Reservoir watershed, Massachusetts, in relation to the dry antecedent periods for storms where runoff samples were collected at U.S. Geological Survey station 01104415. each drainage area at the location of the USGS sampling station using the equation

$$
T=(A / 2.59)^{0.2},
$$

where
$T \quad$ is the time value, in days for the length of the recession period;
$A \quad$ is the area of the drainage basin, in square kilometers $\left(\mathrm{km}^{2}\right)$ upstream from the sampling station;
2.59 is a unit conversion constant; and
0.2 is a constant (Bedient and Huber, 2002).

In calculating a value of $T$ for USGS station 01104460 , the drainage area upstream from the Cambridge Reservoir was excluded from the total drainage area because the flow from the upper basin is regulated and not affected by stormwater runoff. Each automatic sampler was configured to hold one 20 -liter glass bottle and fitted with a pre-cleaned $1 / 2$-in. innerdiameter Teflon intake and discharge tube, and a short piece of silicon pump-head tube.

Physical properties, including water temperature, specific conductance, $\mathrm{pH}$, dissolved oxygen concentration, and turbidity, were measured during the collection of baseflow water samples. These properties, except for dissolved oxygen concentration and temperature, also were measured in the composite samples of stormflow. Water samples were processed in the USGS Massachusetts Water Science Center laboratory in Northborough, Mass., at the conclusion of each sampling. For water samples collected during base-flow conditions when the flow and depth of water in the streams were small, the water generally was collected in the centroid of the stream in separate bottles designated for whole water, dissolved constituents, and organic compounds; therefore, only limited splitting was necessary at the laboratory. For water samples collected during storms, subsamples to be analyzed for inorganic and organic constituents were split directly from the 20-L glass bottle by transferring the water with a Teflondiaphragm pump while the contents of the sample bottle were homogenized with a stainless-steel laboratory mixer. Water to be analyzed for dissolved inorganic constituents was filtered through a $600-\mathrm{cm}^{2}$ (square centimeter) capsule filter with a 0.45 -micrometer pore size. Water to be analyzed for dissolved caffeine, pesticides, and pesticide metabolites was filtered through a 142-millimeter $(\mathrm{mm})$ pre-combusted glass-fiber filter with a nominal $0.7-\mathrm{mm}$ pore diameter to remove suspended particulate matter. After the processing, the samples were packed in ice and shipped overnight to the USGS National Water Quality Laboratory (NWQL), in Lakewood, Colorado, where they were analyzed for concentrations of dissolved major ions, total nutrients, caffeine, and 59 polar pesticides and metabolites (table 3; Patton and Kryskalla, 2003; Furlong and others, 2001; American Public Health Association, 1998; Fishman, 1993; Fishman and Friedman, 1989). Three 


\section{EXPLANATION}
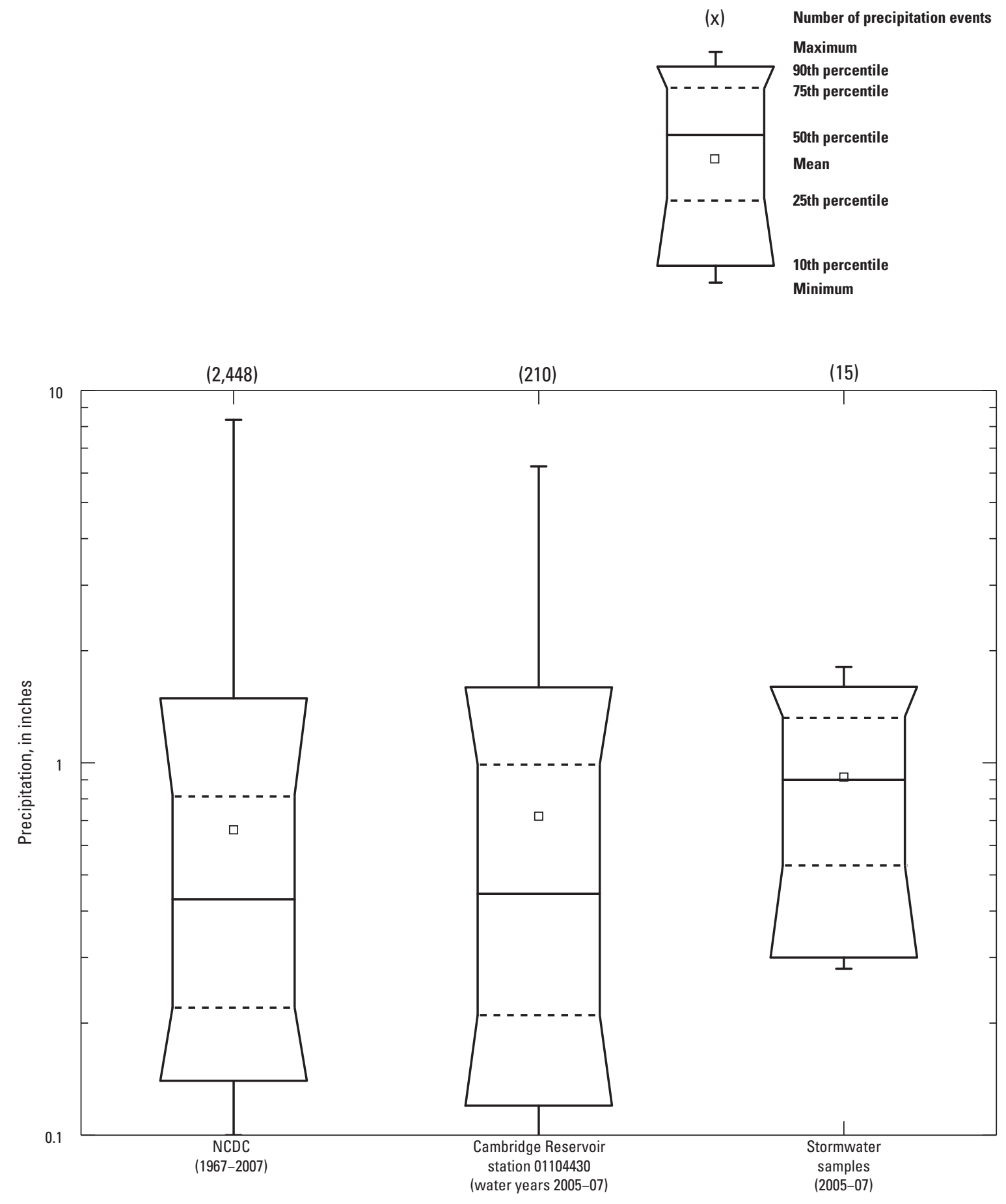

Figure 3. Distribution of precipitation totals greater than 0.10 inch recorded by the National Climatic Data Center near Boston, Massachusetts, 1967-2007; precipitation totals for all storms recorded at the Cambridge Reservoir during water years 2005-07; and precipitation totals for storms during which samples were collected at each of the primary sampling stations in the Cambridge drinkingwater source area, Massachusetts, 2005-07. (NCDC, National Climatic Data Center) 


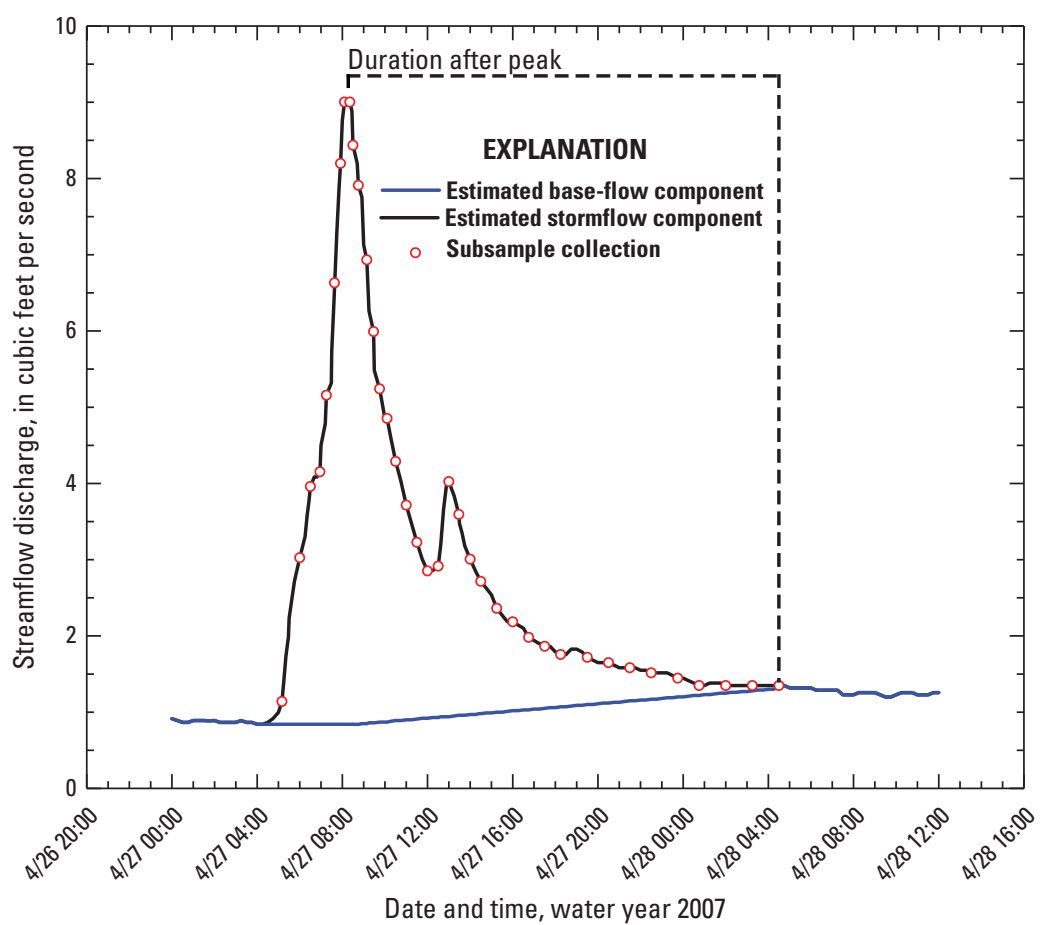

Figure 4. Example of automated flow-proportional collection of stormflow subsamples at U.S. Geological Survey station 01104415, Cambridge drinking-water source area, Massachusetts, water year 2007. base-flow and two storm samples collected in water years 2004 and 2005 also were analyzed for concentrations of suspended sediment, total-recoverable metals, and polyaromatic hydrocarbons (Smith 2005, 2007), although these limited data are not included in this report.

\section{Quality-Assurance and Quality-Control Samples}

Quality-assurance samples were collected to determine bias and precision associated with the sample data. These quality-control samples include 5 field blanks, 15 replicate samples, and 10 field-matrix spike samples (Smith 2008, 2011). Analytical results for these samples provided the basis for the interpretation of chemical data collected in the drinking-water source area. In general, the quality-assurance data indicate that the sample data are relatively free from contamination and analytical results are precise.

A field blank is used to test for positive bias that can result from contamination at any stage of sample collection, processing, or analysis. Field blanks were collected and processed with manual discrete sampling techniques and with stormflow sampling equipment. Trace amounts of $\mathrm{Ca}, \mathrm{Cl}, \mathrm{Na}$, $\mathrm{TN}, \mathrm{TP}$, and caffeine were detected in at least one field blank. These constituents were not detected in samples of the water used as the source of the field blank. However, the maximum concentrations of $\mathrm{Ca}, \mathrm{Cl}, \mathrm{Na}$, and $\mathrm{TN}$ measured in field blanks were one or more orders of magnitude less than the lowest concentrations found in all environmental samples and were within the precision of the analytical methods (Patton and Kryskalla, 2003; Fishman and Friedman, 1989). Concentrations of TP (0.01 milligrams per liter $(\mathrm{mg} / \mathrm{L}))$ and caffeine
(0.008 micrograms per liter $(\mu \mathrm{g} / \mathrm{L}))$ were measured in a single field blank. If it is assumed that the amount of phosphorus and caffeine measured in the field-blank water represents the maximum amount of contamination present in any given sample, the potential positive bias values for concentrations of $\mathrm{TP}$ and caffeine, compared to the mean for all concentrations greater than the detection limit in all samples collected during the study period, are 15 and 5 percent, respectively. No other constituents were detected in field blanks.

Replicate samples are samples that are thought to be identical in composition to the environmental samples. Comparisons of replicate samples provide a measure of bias and variability for the method of sample collection, sample processing (splitting, filtering, and preservation), and laboratory analysis. All replicate samples were collected concurrently using manual sampling techniques, paired automatic samplers, and concurrent manual and automatic sampling techniques (Smith 2008, 2011). The relative percent differences (RPDs) calculated for analytes detected in each pair of replicate samples indicated good agreement between replicates (fig. 5). The mean RPDs for dissolved $\mathrm{Ca}, \mathrm{Cl}, \mathrm{Na}$, and $\mathrm{SO}_{4}$, and $\mathrm{TN}$ were less than 3 percent. The mean RPDs for TP, caffeine, herbicides, insecticides, and fungicides were about 7, 9, 14, 9, and 8 percent, respectively.

Field-matrix spikes are quality-control samples in which known amounts of target compounds are added to a sample. The recovery of spiked analytes is used to assess the bias and variability associated with degradation of target analytes during holding and shipment to the laboratory, the limitations of the analytical method, and interferences contained in the environmental sample that mask or enhance determinations of 
Table 3. Physical properties and constituents measured in water samples, respective long-term method detection limits, and analytical methods.

$[\mu \mathrm{S} / \mathrm{cm}$, microsiemens per centimeter at 25 degrees celsius; LTMDL, long-term method detection level; NTRU, nephelometric turbidity ratio units; USEPA, U.S. Environmental Protection Agency; mg/L, milligrams per liter; $\mu \mathrm{g} / \mathrm{L}$, micrograms per liter; IC, ion chromatography; ICP, inductively coupled plasma; ICP-AES, inductively coupled plasma-atomic emission spectrometry; GCSPE+HPLCMS, graphitized carbon-based solid-phase extraction and high-performance liquid chromatography/mass spectrometry]

\begin{tabular}{|c|c|c|c|c|}
\hline Physical property or constituent & LTMDL & $\begin{array}{l}\text { Analytical } \\
\text { technique }\end{array}$ & $\begin{array}{c}\text { Constituent } \\
\text { detected in one } \\
\text { or more } \\
\text { water samples }\end{array}$ & Reference \\
\hline Turbidity, unfiltered, NTRU & 0.05 & USEPA 180.1 & Yes & Anderson, 2004 \\
\hline pH in standard units & 0.1 & Glass electrode & Yes & Wilde and others, 2006 \\
\hline Specific conductance in $\mu \mathrm{S} / \mathrm{cm}$ & 8 & Wheatstone Bridge & Yes & Radtke and others, 2005 \\
\hline Calcium, filtered, mg/L & 0.01 & ICP-AES & Yes & Fishman, M.J., ed., 1993 \\
\hline Sodium, filtered, mg/L & 0.1 & ICP-AES & Yes & Fishman, M.J., ed., 1993 \\
\hline Chloride, filtered, mg/L & 0.1 & IC & Yes & Fishman and Friedman, 1989 \\
\hline Sulfate, filtered, mg/L & 0.09 & IC & Yes & Fishman and Friedman, 1989 \\
\hline $\begin{array}{l}\text { Total nitrogen }(\text { nitrate }+ \text { nitrite }+ \text { ammonia }+ \\
\text { organic-nitrogen), unfiltered, } \mathrm{mg} / \mathrm{L}\end{array}$ & 0.03 & Alkaline persulfate digestion & Yes & Patton and Kryskalla, 2003 \\
\hline Phosphorus, unfiltered, mg/L & 0.01 & Alkaline persulfate digestion & Yes & Patton and Kryskalla, 2003 \\
\hline 2,4-D methyl ester, $\mu \mathrm{g} / \mathrm{L}$ & 0.1 & GCSPE+HPLCMS & Yes & Furlong and others, 2001 \\
\hline $2,4-\mathrm{D}, \mu \mathrm{g} / \mathrm{L}$ & 0.02 & GCSPE+HPLCMS & Yes & Furlong and others, 2001 \\
\hline $2,4-\mathrm{DB}, \mu \mathrm{g} / \mathrm{L}$ & 0.01 & GCSPE+HPLCMS & No & Furlong and others, 2001 \\
\hline $\begin{array}{l}\text { 2-Chloro-4-isopropylamino-6-amino-s- } \\
\text { triazine, } \mu \mathrm{g} / \mathrm{L}\end{array}$ & 0.014 & GCSPE+HPLCMS & No & Furlong and others, 2001 \\
\hline $\begin{array}{l}\text { 2-Chloro-6-ethylamino-4-amino-s-triazine } \\
\text { (CEAT), } \mu \mathrm{g} / \mathrm{L}\end{array}$ & 0.04 & GCSPE+HPLCMS & Yes & Furlong and others, 2001 \\
\hline $\begin{array}{l}\text { 2-Hydroxy-4-isopropylamino-6-ethylamino- } \\
\text { s-triazine (OIET), } \mu \mathrm{g} /\end{array}$ & 0.04 & GCSPE+HPLCMS & Yes & Furlong and others, 2001 \\
\hline 3-Hydroxy carbofuran, $\mu \mathrm{g} / \mathrm{L}$ & 0.004 & GCSPE+HPLCMS & No & Furlong and others, 2001 \\
\hline Acifluorfen, $\mu \mathrm{g} / \mathrm{L}$ & 0.014 & GCSPE+HPLCMS & No & Furlong and others, 2001 \\
\hline Aldicarb sulfone, $\mu \mathrm{g} / \mathrm{L}$ & 0.009 & GCSPE+HPLCMS & No & Furlong and others, 2001 \\
\hline Aldicarb sulfoxide, $\mu \mathrm{g} / \mathrm{L}$ & 0.02 & GCSPE+HPLCMS & No & Furlong and others, 2001 \\
\hline Aldicarb, $\mu \mathrm{g} / \mathrm{L}$ & 0.02 & GCSPE+HPLCMS & No & Furlong and others, 2001 \\
\hline Atrazine, $\mu \mathrm{g} / \mathrm{L}$ & 0.004 & GCSPE+HPLCMS & & Furlong and others, 2001 \\
\hline Bendiocarb, $\mu \mathrm{g} / \mathrm{L} 0.02$ & 0.02 & GCSPE+HPLCMS & No & Furlong and others, 2001 \\
\hline Benomyl, $\mu \mathrm{g} / \mathrm{L}$ & 0.011 & GCSPE+HPLCMS & Yes & Furlong and others, 2001 \\
\hline Bensulfuron-methyl, $\mu \mathrm{g} / \mathrm{L}$ & 0.009 & GCSPE+HPLCMS & No & Furlong and others, 2001 \\
\hline Bentazon, $\mu \mathrm{g} / \mathrm{L}$ & 0.01 & GCSPE+HPLCMS & No & Furlong and others, 2001 \\
\hline Bromacil, $\mu \mathrm{g} / \mathrm{L}$ & 0.009 & GCSPE+HPLCMS & No & Furlong and others, 2001 \\
\hline Bromoxynil, $\mu \mathrm{g} / \mathrm{L}$ & 0.06 & GCSPE+HPLCMS & No & Furlong and others, 2001 \\
\hline Carbaryl, $\mu \mathrm{g} / \mathrm{L}$ & 0.009 & GCSPE+HPLCMS & Yes & Furlong and others, 2001 \\
\hline Carbofuran, $\mu \mathrm{g} / \mathrm{L}$ & 0.008 & GCSPE+HPLCMS & No & Furlong and others, 2001 \\
\hline Chloramben methyl ester, $\mu \mathrm{g} / \mathrm{L}$ & 0.012 & GCSPE+HPLCMS & No & Furlong and others, 2001 \\
\hline
\end{tabular}




\section{Water Quality in the Cambridge Drinking-Water Source Area, Massachusetts, Water Years 2005-07}

Table 3. Physical properties and constituents measured in water samples, respective long-term method detection limits, and analytical methods.-Continued

$[\mu \mathrm{S} / \mathrm{cm}$, microsiemens per centimeter at 25 degrees celsius; LTMDL, long-term method detection level; NTRU, nephelometric turbidity ratio units; USEPA, U.S. Environmental Protection Agency; mg/L, milligrams per liter; $\mu \mathrm{g} / \mathrm{L}$, micrograms per liter; IC, ion chromatography; ICP, inductively coupled plasma; ICP-AES, inductively coupled plasma-atomic emission spectrometry; GCSPE+HPLCMS, graphitized carbon-based solid-phase extraction and high-performance liquid chromatography/mass spectrometry]

\begin{tabular}{|c|c|c|c|c|}
\hline Physical property or constituent & LTMDL & $\begin{array}{l}\text { Analytical } \\
\text { technique }\end{array}$ & $\begin{array}{c}\text { Constituent } \\
\text { detected in one } \\
\text { or more } \\
\text { water samples }\end{array}$ & Reference \\
\hline Chlorimuron-ethyl, $\mu \mathrm{g} / \mathrm{L}$ & 0.016 & GCSPE+HPLCMS & No & Furlong and others, 2001 \\
\hline Chlorodiamino-s-triazine, $\mu \mathrm{g} / \mathrm{L}$ & 0.02 & GCSPE+HPLCMS & No & Furlong and others, 2001 \\
\hline Clopyralid, $\mu \mathrm{g} / \mathrm{L}$ & 0.03 & GCSPE+HPLCMS & No & Furlong and others, 2001 \\
\hline Cycloate, $\mu \mathrm{g} / \mathrm{L}$ & 0.007 & GCSPE+HPLCMS & No & Furlong and others, 2001 \\
\hline Dacthal monoacid, $\mu \mathrm{g} / \mathrm{L}$ & 0.014 & GCSPE+HPLCMS & No & Furlong and others, 2001 \\
\hline Dicamba, $\mu \mathrm{g} / \mathrm{L}$ & 0.018 & GCSPE+HPLCMS & No & Furlong and others, 2001 \\
\hline Dichlorprop, $\mu \mathrm{g} / \mathrm{L}$ & 0.014 & GCSPE+HPLCMS & No & Furlong and others, 2001 \\
\hline Dinoseb, $\mu \mathrm{g} / \mathrm{L}$ & 0.019 & GCSPE+HPLCMS & Yes & Furlong and others, 2001 \\
\hline Diphenamid, $\mu \mathrm{g} / \mathrm{L}$ & 0.005 & GCSPE+HPLCMS & No & Furlong and others, 2001 \\
\hline Diuron, $\mu \mathrm{g} / \mathrm{L}$ & 0.02 & GCSPE+HPLCMS & Yes & Furlong and others, 2001 \\
\hline Fenuron, $\mu \mathrm{g} / \mathrm{L}$ & 0.02 & GCSPE+HPLCMS & Yes & Furlong and others, 2001 \\
\hline Flumetsulam, $\mu \mathrm{g} / \mathrm{L}$ & 0.02 & GCSPE+HPLCMS & Yes & Furlong and others, 2001 \\
\hline Fluometuron, $\mu \mathrm{g} / \mathrm{L}$ & 0.008 & GCSPE+HPLCMS & Yes & Furlong and others, 2001 \\
\hline Imazaquin, $\mu \mathrm{g} / \mathrm{L}$ & 0.018 & GCSPE+HPLCMS & Yes & Furlong and others, 2001 \\
\hline Imazethapyr, $\mu \mathrm{g} / \mathrm{L}$ & 0.019 & GCSPE+HPLCMS & No & Furlong and others, 2001 \\
\hline Imidacloprid, $\mu \mathrm{g} / \mathrm{L}$ & 0.03 & GCSPE+HPLCMS & Yes & Furlong and others, 2001 \\
\hline Linuron, $\mu \mathrm{g} / \mathrm{L}$ & 0.007 & GCSPE+HPLCMS & No & Furlong and others, 2001 \\
\hline $\mathrm{MCPA}, \mu \mathrm{g} / \mathrm{L}$ & 0.03 & GCSPE+HPLCMS & Yes & Furlong and others, 2001 \\
\hline $\mathrm{MCPB}, \mu \mathrm{g} / \mathrm{L}$ & 0.1 & GCSPE+HPLCMS & No & Furlong and others, 2001 \\
\hline Metalaxyl, $\mu \mathrm{g} / \mathrm{L}$ & 0.02 & GCSPE+HPLCMS & Yes & Furlong and others, 2001 \\
\hline Methiocarb, $\mu \mathrm{g} / \mathrm{L}$ & 0.02 & GCSPE+HPLCMS & No & Furlong and others, 2001 \\
\hline Methomyl, $\mu \mathrm{g} / \mathrm{L}$ & 0.03 & GCSPE+HPLCMS & No & Furlong and others, 2001 \\
\hline Metsulfuron-methyl, $\mu \mathrm{g} / \mathrm{L}$ & 0.07 & GCSPE+HPLCMS & Yes & Furlong and others, 2001 \\
\hline N-(4-Chlorophenyl)-N'-methylurea, $\mu \mathrm{g} / \mathrm{L}$ & 0.018 & GCSPE+HPLCMS & No & Furlong and others, 2001 \\
\hline Neburon, $\mu \mathrm{g} / \mathrm{L}$ & 0.006 & GCSPE+HPLCMS & No & Furlong and others, 2001 \\
\hline Nicosulfuron, $\mu \mathrm{g} / \mathrm{L}$ & 0.02 & GCSPE+HPLCMS & No & Furlong and others, 2001 \\
\hline Norflurazon, $\mu \mathrm{g} / \mathrm{L}$ & 0.01 & GCSPE+HPLCMS & Yes & Furlong and others, 2001 \\
\hline Oryzalin, $\mu \mathrm{g} / \mathrm{L}$ & 0.02 & GCSPE+HPLCMS & No & Furlong and others, 2001 \\
\hline Oxamyl, $\mu \mathrm{g} / \mathrm{L}$ & 0.02 & GCSPE+HPLCMS & Yes & Furlong and others, 2001 \\
\hline Picloram, $\mu \mathrm{g} / \mathrm{L}$ & 0.016 & GCSPE+HPLCMS & No & Furlong and others, 2001 \\
\hline Propham, $\mu \mathrm{g} / \mathrm{L}$ & 0.015 & GCSPE+HPLCMS & No & Furlong and others, 2001 \\
\hline Propiconazole, $\mu \mathrm{g} / \mathrm{L}$ & 0.005 & GCSPE+HPLCMS & Yes & Furlong and others, 2001 \\
\hline
\end{tabular}


Table 3. Physical properties and constituents measured in water samples, respective long-term method detection limits, and analytical methods. - Continued

$[\mu \mathrm{S} / \mathrm{cm}$, microsiemens per centimeter at 25 degrees celsius; LTMDL, long-term method detection level; NTRU, nephelometric turbidity ratio units; USEPA, U.S. Environmental Protection Agency; mg/L, milligrams per liter; $\mu \mathrm{g} / \mathrm{L}$, micrograms per liter; IC, ion chromatography; ICP, inductively coupled plasma; ICP-AES, inductively coupled plasma-atomic emission spectrometry; GCSPE+HPLCMS, graphitized carbon-based solid-phase extraction and high-performance liquid chromatography/mass spectrometry]

\begin{tabular}{|c|c|c|c|c|}
\hline Physical property or constituent & LTMDL & $\begin{array}{l}\text { Analytical } \\
\text { technique }\end{array}$ & $\begin{array}{c}\text { Constituent } \\
\text { detected in one } \\
\text { or more } \\
\text { water samples }\end{array}$ & Reference \\
\hline Propoxur, $\mu \mathrm{g} / \mathrm{L}$ & 0.004 & GCSPE+HPLCMS & Yes & Furlong and others, 2001 \\
\hline Siduron, $\mu \mathrm{g} / \mathrm{L}$ & 0.01 & GCSPE+HPLCMS & Yes & Furlong and others, 2001 \\
\hline Sulfometuron-methyl, $\mu \mathrm{g} / \mathrm{L}$ & 0.03 & GCSPE+HPLCMS & Yes & Furlong and others, 2001 \\
\hline Tebuthiuron, $\mu \mathrm{g} / \mathrm{L}$ & 0.013 & GCSPE+HPLCMS & Yes & Furlong and others, 2001 \\
\hline Terbacil, $\mu \mathrm{g} / \mathrm{L}$ & 0.02 & GCSPE+HPLCMS & No & Furlong and others, 2001 \\
\hline Triclopyr, $\mu \mathrm{g} / \mathrm{L}$ & 0.02 & GCSPE+HPLCMS & Yes & Furlong and others, 2001 \\
\hline Caffeine, $\mu \mathrm{g} / \mathrm{L}$ & 0.02 & GCSPE+HPLCMS & Yes & Furlong and others, 2001 \\
\hline
\end{tabular}

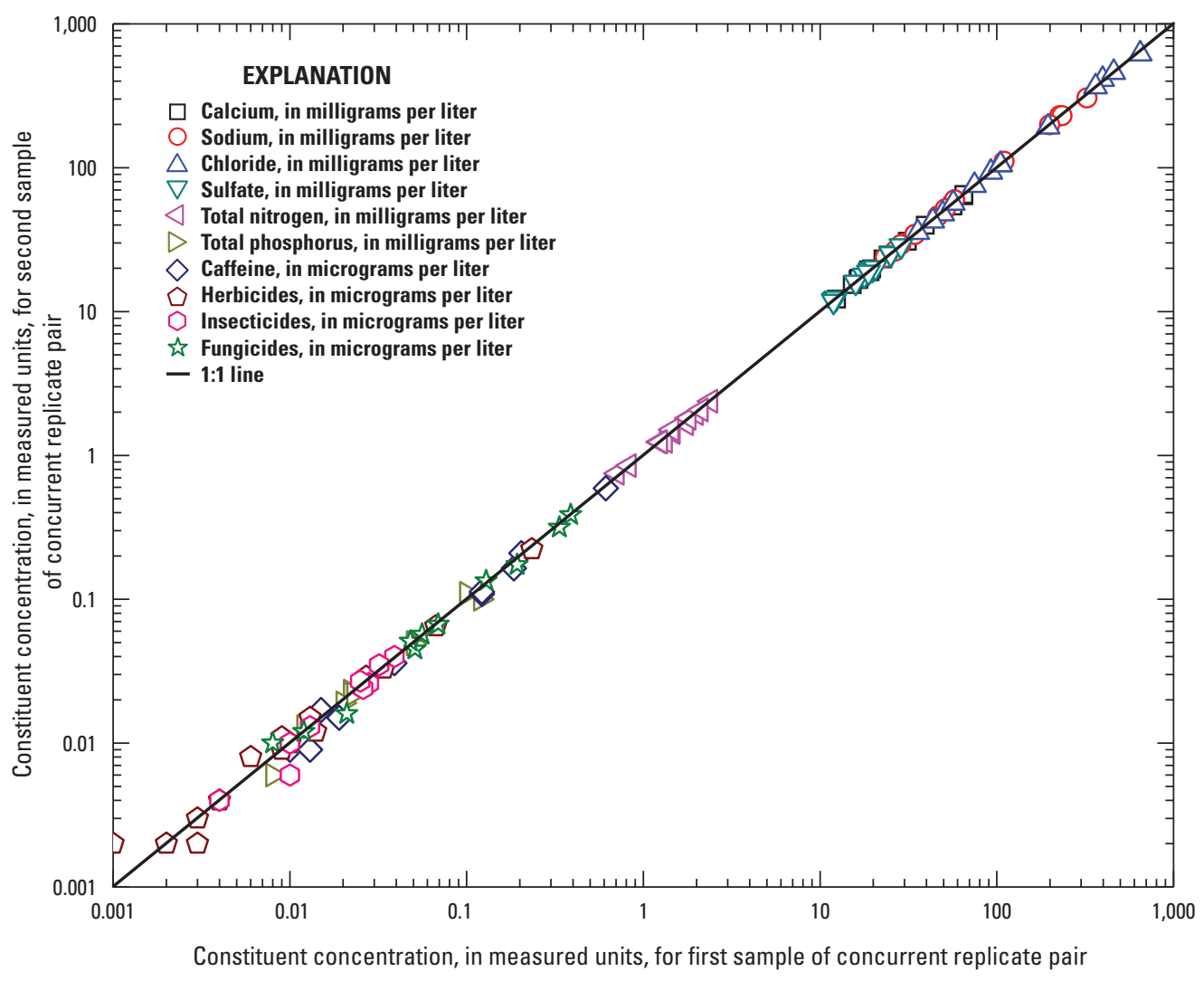

Figure 5. Relation of concentrations of selected constituents detected in concurrent replicate streamflow samples, Cambridge drinking-water source area, Massachusetts, water years 2005-07. (Symbols showing fungicides, herbicides, and insecticides represent concentrations of individual compounds listed in table 7). 
the target analytes. Samples are routinely spiked in the laboratory to provide a measure of method performance. In general, laboratory spike recoveries for pesticides vary widely. For example, during water years $2007-08$, the median value for the lower and upper 99-percent confidence limits for recovery of spiked analytes in laboratory preparation samples for the pesticides listed in table 3 ranged from about 30 to 140 percent (Smith, 2011). Recovery values for compounds in spiked environmental samples will at best fall within laboratory recovery criteria. Approximately 17 percent of the recoveries of spiked pesticides were outside of the laboratory recovery criteria; however, recoveries for most of the pesticides that were routinely detected met method criteria. Most recoveries that were outside of the method criteria tended to be low, particularly in water year 2007 (Smith 2011). The median RPD for replicate field spike samples was less than 12 percent, which indicates that although recoveries were low for some constituents, analytical methods were relatively precise.

\section{Data Analysis Methods}

Water-quality data were statistically analyzed to determine the relation between streamflow and land use, to calculate constituent loads and yields, and to assess temporal trends in selected constituents. A correlation analysis was performed relating concentrations of selected constituents to streamflow and subbasin characteristics. Concentration data, along with continuous records of streamflow and specific conductance, were used to estimate loads and yields of selected constituents during the study period. Trend analysis was performed for annual loads of $\mathrm{Cl}$ and $\mathrm{Na}$ for selected USGS streamgages during water years 1998-2008.

\section{Determination of Correlations}

To examine factors affecting water quality in the drinking-water source area, a correlation analysis was performed relating constituent concentrations to the logarithmic values of streamflow and to subbasin land-use characteristics. Correlation analysis was performed for annual flow-weighted concentrations of $\mathrm{Ca}, \mathrm{Cl}, \mathrm{Na}, \mathrm{SO}_{4}, \mathrm{TN}, \mathrm{TP}$, caffeine, and selected pesticides in water samples collected at four primary USGS monitoring stations on the tributaries in the drinking-water source area during water years 2005-07. A correlation analysis also was performed relating subbasin land-use characteristics to mean concentrations of $\mathrm{Ca}, \mathrm{Cl}, \mathrm{Na}, \mathrm{SO}_{4}, \mathrm{TN}$, and $\mathrm{TP}$ and to maximum concentrations of caffeine and selected pesticides in samples collected from the primary and secondary sampling stations (fig. 1), except for USGS stations 01104430 and 1104460 where the quality of upstream water is affected by flow regulation, settling, and residence time in the Cambridge Reservoir.

The Pearson product moment correlation coefficient was used for the correlation analysis. This method measures the degree of linear relations between two variables. The correlation coefficient ranges from -1 to +1 (Helsel and Hirsch, 2002). A negative coefficient indicates that one variable tends to increase as the other decreases, and a positive coefficient indicates that the two variables tend to increase together. The absolute value of the correlation coefficient indicates the strength of the relation between variables. Cohen (1988) describes correlation coefficients with an absolute value greater than 0.71 , where the correlation between two variables is one in which at least 50 percent (the square of the correlation coefficient) of the variance in one variable is accounted for by the variance of the other variable, as strong. Furthermore, correlation coefficients with absolute values less than 0.71 indicate a moderate to weak correlation, where less than one-half of the variance in one variable is accounted for by the other variable. In the following discussions, a correlation coefficient with an absolute value of 0.9 or larger indicates a strong linear relation, and a correlation coefficient with an absolute value between 0.71 and 0.90 indicates a moderately strong correlation.

\section{Estimated Loads and Yields}

Loads are the quantity of a constituent transported by a stream during a specific time interval and are determined by multiplying the concentration or mass of a constituent by the streamflow. Yields are loads normalized by the drainage area of each subbasin. Loads and yields of $\mathrm{Ca}, \mathrm{Cl}, \mathrm{Na}, \mathrm{SO}_{4}$, $\mathrm{TN}$, TP, selected pesticides, and caffeine were estimated from analyte concentrations in samples of base flow and stormflow and from streamflow data at the five primary sampling stations for water years 2005 to 2007 . Loads and yields of $\mathrm{Ca}, \mathrm{Cl}$, $\mathrm{Na}$, and $\mathrm{SO}_{4}$ also were estimated from continuous records of streamflow and specific conductance, and relations between dissolved major ions and specific conductance for all monitoring stations with these records. Yields were estimated using available data for each of the monitoring stations (table 1).

\section{Loads Estimated from Streamflow}

Various methods are available to estimate loads using constituent-concentration data and streamflow. In some cases, loads can be estimated on the basis of correlations between concentration data and streamflow. In this study, relations between discrete sample concentrations of selected constituents and instantaneous flow at the time of sample collection, and concentrations of selected constituents in composite samples and mean flow of each storm, were examined. Although the correlation between concentrations of most major ions and streamflow was significant $(p<0.05)$, the strength of the relations typically was not strong (less than 0.90 ; table 4 ). Correlations between concentrations of major ions and streamflow at USGS station 01104475 were not significant, except for $\mathrm{Ca}$, and all of the relations were weak. The correlation between TP concentration and streamflow was significant for three primary 
Table 4. Pearson correlation coefficients relating concentrations of major ions and total nutrients to streamflow at five U.S. Geological Survey monitoring/sampling stations in the Cambridge and Stony Brook Reservoir watersheds, Massachusetts, water years 2005-07.

[Shaded areas indicate values that are significant at a 95-percent confidence level; data include one sample collected during water year 2004. USGS, U.S. Geological Survey]

\begin{tabular}{rccccccc}
$\begin{array}{c}\text { USGS } \\
\text { station }\end{array}$ & $\begin{array}{c}\text { Number } \\
\text { of } \\
\text { samples }\end{array}$ & $\begin{array}{c}\text { Dissolved } \\
\text { calcium }\end{array}$ & $\begin{array}{c}\text { Dissolved } \\
\text { chloride }\end{array}$ & $\begin{array}{c}\text { Dissolved } \\
\text { sodium }\end{array}$ & $\begin{array}{c}\text { Dissolved } \\
\text { sulfate }\end{array}$ & $\begin{array}{c}\text { Total } \\
\text { phosphorus }\end{array}$ & $\begin{array}{c}\text { Total } \\
\text { nitrogen }\end{array}$ \\
\hline 01104415 & 30 & -0.70 & -0.50 & -0.52 & -0.28 & 0.59 & 0.32 \\
01104433 & 29 & -0.80 & -0.66 & -0.64 & -0.78 & 0.62 & -0.31 \\
01104455 & 30 & -0.84 & -0.81 & -0.83 & -0.91 & 0.80 & 0.35 \\
01104460 & 24 & -0.80 & -0.48 & -0.42 & -0.21 & 0.33 & 0.32 \\
01104475 & 30 & -0.49 & -0.06 & -0.02 & -0.29 & 0.04 & -0.21 \\
\hline
\end{tabular}

sampling stations (USGS stations 01104415, 01104433, and 01104455); however, the relations were not strong. The correlation between $\mathrm{TN}$ concentration and streamflow was not significant for any of the five primary sampling stations. The correlation between pesticide concentrations and streamflow was not calculated because the frequency of detection of most pesticides was low and because the relations were expected to be weak since pesticides are applied once or twice during specific times each year and often are mobilized only during storms. In general, correlations between constituent concentrations and streamflow were neither consistently significant nor strong for the five primary sampling stations; however, many of these relations indicate that the concentrations of major ions tended to decrease with increasing flow and the concentration of TP tended to increase with increasing flow.

Because the correlations between constituent concentrations and streamflow for the five primary sampling stations were not sufficiently strong, loads were estimated on the basis of streamflow and a measure of the central tendency of each constituent using a stratified flow approach. Mean concentration, as opposed to medians, are particularly appropriate for characterizing loads because including outlier values (either high or low), which typically represent large flows, is important when characterizing transport of constituent masses.

Data used to estimate loads were stratified into two classes (base flow and stormflow). The stratification was performed on the basis of the two sampling strategies and the separation of streamflow into a strictly base-flow component and a stormflow component that represent the sum of base flow, bank storage, and overland stormwater runoff. Continuous streamflow records for each of the five primary sampling stations were separated into these two components on the basis of the stormflow sampling algorithm described earlier. This method for identifying the period of the storm runoff is consistent with the fixed-base method used for hydrograph separation and described by Chow and others (1988), although in this study, the method was used only to identify the beginning and end of each storm and the associated volume of flow between these two points.

The Mann-Whitney test, also referred to as the rank-sum test, was used to determine whether constituent concentrations in base-flow and stormflow samples differed statistically ( $p$ value less than 0.05). The Mann-Whitney test is a nonparametric method that makes no assumptions about the distribution of data and is used to determine whether groups of data come from the same population or alternatively whether the median values are different (Helsel and Hirsch, 2002). For constituents that were not detected or were present at levels less than the long-term method detection level (LTMDL; censored data), concentrations were set equal to a value less than the respective LTMDL. The LTMDL is the lowest detectable concentration of an analyte that can be measured and reported with 99-percent confidence when the concentration is greater than zero. The chance of falsely reporting a concentration at or greater than the LTMDL for a sample that does not contain the analyte is predicted to be less than or equal to 1 percent (Childress and others, 1999). For analytes not detected in samples, a concentration equal to twice the LTMDL value (laboratory reporting limit) is reported with a "less than" $(<)$ remark code in all data tables in this report. The substitution of a value less than the LTMDL approach is appropriate for rank-based nonparametric analysis methods for singly censored data (Helsel, 2005). Base-flow and stormflow concentrations of pesticides were not compared because pesticides were infrequently detected and the median value typically was censored.

With a few exceptions, concentrations of major ions and total nutrients in base-flow samples and stormflow composite samples were significantly different (table 5), and an independent mean concentration was determined for each data set. Where base-flow and stormflow concentrations of constituents were not significantly different, the mean concentration was determined from the combined dataset. For example, base-flow and stormflow concentrations of TN at USGS stations 01104415,01104460 , and 01104475 did not differ 
Table 5. Attained significance levels ( $p$ values) from Mann-Whitney tests for paired sample sets of concentrations of selected constituents and properties collected during base-flow and stormflow conditions in the Cambridge drinkingwater source area, Massachusetts, water years 2005-07.

[USGS, U.S. Geological Survey; <, Less than; shaded areas indicate values that are significant at a 95-percent confidence interval; data include one sample each collected during water year 2004 at USGS stations $01104415,01104433,01104455$, and 01104475 ]

\begin{tabular}{lccccc}
\hline \multirow{2}{*}{ Constituent or property } & \multicolumn{5}{c}{ USGS station } \\
\cline { 2 - 6 } & $\mathbf{0 1 1 0 4 4 1 5}$ & $\mathbf{0 1 1 0 4 4 3 3}$ & $\mathbf{0 1 1 0 4 4 5 5}$ & $\mathbf{0 1 1 0 4 4 6 0}$ & $\mathbf{0 1 1 0 4 4 7 5}$ \\
\hline Number of values & 30 & 29 & 30 & 24 & 30 \\
Chloride & 0.051 & $<0.001$ & $<0.001$ & 0.355 & 0.135 \\
Sodium & 0.056 & $<0.001$ & $<0.001$ & 0.371 & 0.130 \\
Calcium & $<0.001$ & $<0.001$ & $<0.001$ & 0.019 & $<0.001$ \\
Sulfate & 0.016 & $<0.001$ & $<0.001$ & 0.023 & 0.001 \\
& & & & 0.852 \\
Nitrogen, total & 0.395 & 0.023 & 0.0039 & 0.977 & $<0.001$ \\
Phosphorus, total & $<0.001$ & $<0.001$ & $<0.001$ & 0.002 & 0.018 \\
pH & 0.181 & 0.130 & 0.427 & 0.048 & $<0.001$ \\
Turbidity & $<0.001$ & $<0.001$ & $<0.001$ & 0.204 & 0.047 \\
Specific Conductance & 0.038 & 0.001 & $<0.001$ & 0.215 & \\
\hline
\end{tabular}

significantly and were considered a non-stratified dataset for each of the respective stations.

Concentrations of many pesticides generally were below the LTMDL and were reported as censored data (Smith, 2005, 2007, 2008, and 2011). In a few cases, concentrations of TP and caffeine also were censored. Sample means for these analytes were estimated using the regression-on-order statistics (ROS) method. The ROS method is considered robust for the estimation of summary statistics for data sets with censored values (Helsel, and Cohn, 1988; Shumway and others 2002; Helsel, 2005) and is appropriate when 80 percent or less of the data are censored (Helsel, 2005).

The distribution of many constituent concentrations, particularly TP in stormflow and pesticides and caffeine in stormflow and base flow, was lognormal rather than normal. For these constituents, means were estimated by assuming that the logarithms of the data were symmetric. This method provides a more reliable estimate of the population mean than the simple arithmetic sample mean without log transformation (Helsel and Hirsch, 2002).

\section{Loads of Major lons Estimated from Specific- Conductance Monitoring Data}

Specific conductance measurements, which commonly are used to approximate concentrations of dissolved major ions (Hem, 1982, 1992; Miller and others, 1988; Church and others, 1996; Granato and Smith, 1999; Smith and Granato, 2010; Smith and Breault, 2011), are used in this study to estimate concentrations of dissolved $\mathrm{Ca}, \mathrm{Cl}, \mathrm{Na}$, and $\mathrm{SO}_{4}$ in tributary water and to estimate concentrations and loads of these constituents in the drinking-water source area. Concentrations of dissolved $\mathrm{Ca}, \mathrm{Cl}, \mathrm{Na}$, and $\mathrm{SO}_{4}$ were measured in base-flow and stormflow samples (24-31 samples from primary sampling stations and 3 samples from secondary sampling stations during the study) but also were estimated from the more frequent, in-situ measurements of specific conductance. In comparison to the limited data from the water-quality samples, continuous records of specific conductance are available for all of the primary sampling stations and some secondary sampling stations in the drinking-water source area. These continuous specific conductance data are available for nearly every day of the study and represent a variety of hydrologic conditions (base flow, rain, mixed precipitation, and snowmelt runoff events).

Instantaneous concentrations of $\mathrm{Ca}, \mathrm{Cl}, \mathrm{Na}$, and $\mathrm{SO}_{4}$ were estimated from continuous measurements of specific conductance by using equations developed to relate specific conductance to concentrations of the respective ions (eq. 2 below). These regression equations were developed using the MOVE.1 technique (Maintenance Of Variance-Extension, type 1), also known as the line of organic correlation (Helsel and Hirsch, 1992; Hirsch, 1982), on the basis of concurrent measurements of log-transformed values of specific conductance and concentrations of $\mathrm{Ca}, \mathrm{Cl}, \mathrm{Na}$, and $\mathrm{SO}_{4}$ in samples collected from tributaries in the drinking-water source area. The data set for the study period includes 178 concentrations for these ions, where specific conductance values ranged from 67 to 30,100 microsiemens per centimeter at 25 degrees Celsius $(\mu \mathrm{S} / \mathrm{cm})($ Smith, 2005, 2007, and 2011; U.S. Geological Survey, 2001). The MOVE.1 technique was chosen for regression analysis because it minimizes errors in both the $\mathrm{x}$ and $\mathrm{y}$ directions, producing a unique equation that can be used to predict either variable from the other (Helsel and Hirsch, 1992). 


$$
C=\left(S p c^{m}\right) \times b,
$$

where

$$
\begin{aligned}
& C \text { is the concentration of the ion of interest, } \\
& \text { in } \mathrm{mg} / \mathrm{L} \text {; } \\
& \text { Spc is the specific conductance, in } \mu \mathrm{S} / \mathrm{cm} \text {; } \\
& m \text { is the slope from the MOVE.1 analysis } \\
& \text { (table 6); and } \\
& b \quad \text { is the intercept from the MOVE. } 1 \text { analysis } \\
& \text { (table 6). }
\end{aligned}
$$

These equations were optimized for each site on the basis of the milliequivalent ratio of each ion to $\mathrm{Cl}$. Expressing concentrations in terms of milliequivalents normalized the charge of each ion. The mean ratios of $\mathrm{Ca}: \mathrm{Cl}, \mathrm{Na}: \mathrm{Cl}$, and $\mathrm{SO}_{4}: \mathrm{Cl}$ were estimated for each station (fig 6). Separate equations were developed for each constituent and for stations where the ratios of the constituent to $\mathrm{Cl}$ were very different from others, based on visual inspection of boxplots of the data (for example, station 01104475, fig. 6). Individual equations were developed to relate measurements of specific conductance to concentrations of $\mathrm{Ca}$, except for USGS stations 01104430 and 01104455 for which a single equation was developed. One equation was developed to relate measurements of specific conductance to concentrations of $\mathrm{Cl}, \mathrm{Na}$, and $\mathrm{SO}_{4}$ for all USGS stations, except USGS station 01104475 which required a separate equation to optimize the root mean square error. These equations provide reasonable estimates for dissolved concentrations of $\mathrm{Ca}, \mathrm{Cl}, \mathrm{Na}$, and $\mathrm{SO}_{4}$ on the basis of specific conductance measurements.

Annual loads of $\mathrm{Ca}, \mathrm{Cl}, \mathrm{Na}$, and $\mathrm{SO}_{4}$ were estimated for the period of record for all sampling sites for which streamflow and continuous specific-conductance data were available (except for loads previously calculated using similar methods for water year 1998 and reported by Waldron and Bent, 2001). Loads for USGS stations 01104430 and 01104460 (stations where flow is regulated by the CWD) were calculated by multiplying estimated daily flow-weighted concentrations of $\mathrm{Ca}$, $\mathrm{Cl}, \mathrm{Na}$, and $\mathrm{SO}_{4}$, in milligrams per liter, by daily flow, in liters per day, and added. For USGS stations 01104415, 01104433, 011004455 , and 01104475 , which are primary sampling stations where both base-flow and stormflow samples were collected, annual base-flow and stormflow loads were estimated, in part, using the area-base hydrograph separation method described earlier. However, in this instance, the stormflow component is separated from the base-flow component as opposed to simply estimating the total volume of flow between the beginning and ending of each period of stormflow. Unlike the previous load estimation method that is based on the central tendency of constituent concentrations in base flow and stormflow where the concentration of a constituent of interest is unknown at any given point in time (except for the actual sample time), this method enables a flow-weighted concentration to be estimated from records of streamflow and specific conductance. In this case, the specific conductance in base flow just prior to a runoff event (rain, mixed precipitation, or snow melt) is assigned to the initial base-flow component during the event. Similar to the fixed-base method for hydrograph separation, the assigned base-flow specific conductance is extended to the peak flow as long as a mass balance between the base-flow specific conductance and stormflow specific conductance is achieved. Beginning with the point of peak flow, the specific conductance assigned to the base-flow component is adjusted over time for the remainder of the event on the basis of the slope derived from the starting specific conductance value and the specific conductance on the recession limb of the hydrograph at the end of the event (fig 7). During this projection, the specific conductance initially assigned to the base-flow component decreases with time. This is a typical response in the subbasins in this study because groundwater containing higher concentrations of major ions mixes with subsurface flow (rain water which has infiltrated into the ground) containing low concentrations of major ions (National Atmospheric Deposition Program, 2008) and discharges to the stream. The daily flow for USGS stations 01104415 , 01104433, 011004455, and 01104475, representing base flow and stormflow, was summed by water year. Annual base-flow and stormflow loads of $\mathrm{Ca}, \mathrm{Cl}, \mathrm{Na}$, and $\mathrm{SO}_{4}$ for USGS stations $01104415,01104433,011004455$, and 01104475 were calculated by multiplying daily flow-weighted concentrations associated with each flow component by the respective daily flow, in liters per day, and summed for each water year.

It is difficult to assess the accuracy of simplified hydrograph separation techniques because the methods to estimate base flow are based solely on drainage area and, therefore, do not include the effects of various basin features that may be either natural or anthropogenic. Stormflow end points resulting from the fixed-base method for hydrograph separation in this study generally agree with end points subjectively chosen in analysis of storm hydrographs at each of the USGS stations. Continuous measurements of specific conductance, which were used in other studies to aid in base-flow separation (Pellerin and others, 2007; Yu and Schwartz, 1999; Matsubayashi and others, 1993; Pilgrim and others, 1979; and Pinder and Jones, 1969), also tend to asymptotically converge with initial base-flow values (fig. 7) at the end points resulting from the separation method used in this study. Nevertheless, the accuracy of results from the simplified method for individual storms is likely variable. These methods provide an estimate of the volume of water and load of constituents associated with each component of flow, and errors in estimates of baseflow volume may balance out over long periods of time. Loads estimated for each component of flow are important as this information is useful in assessing best-management practices (BMPs) or land-use changes in the drinking-water source area. 


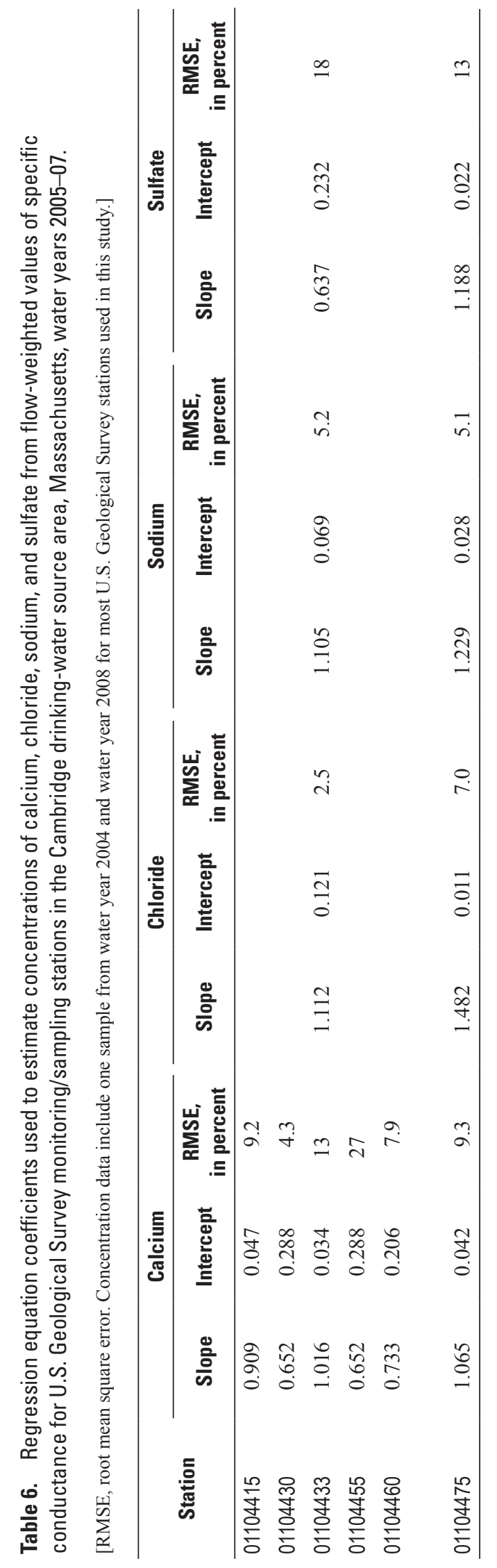



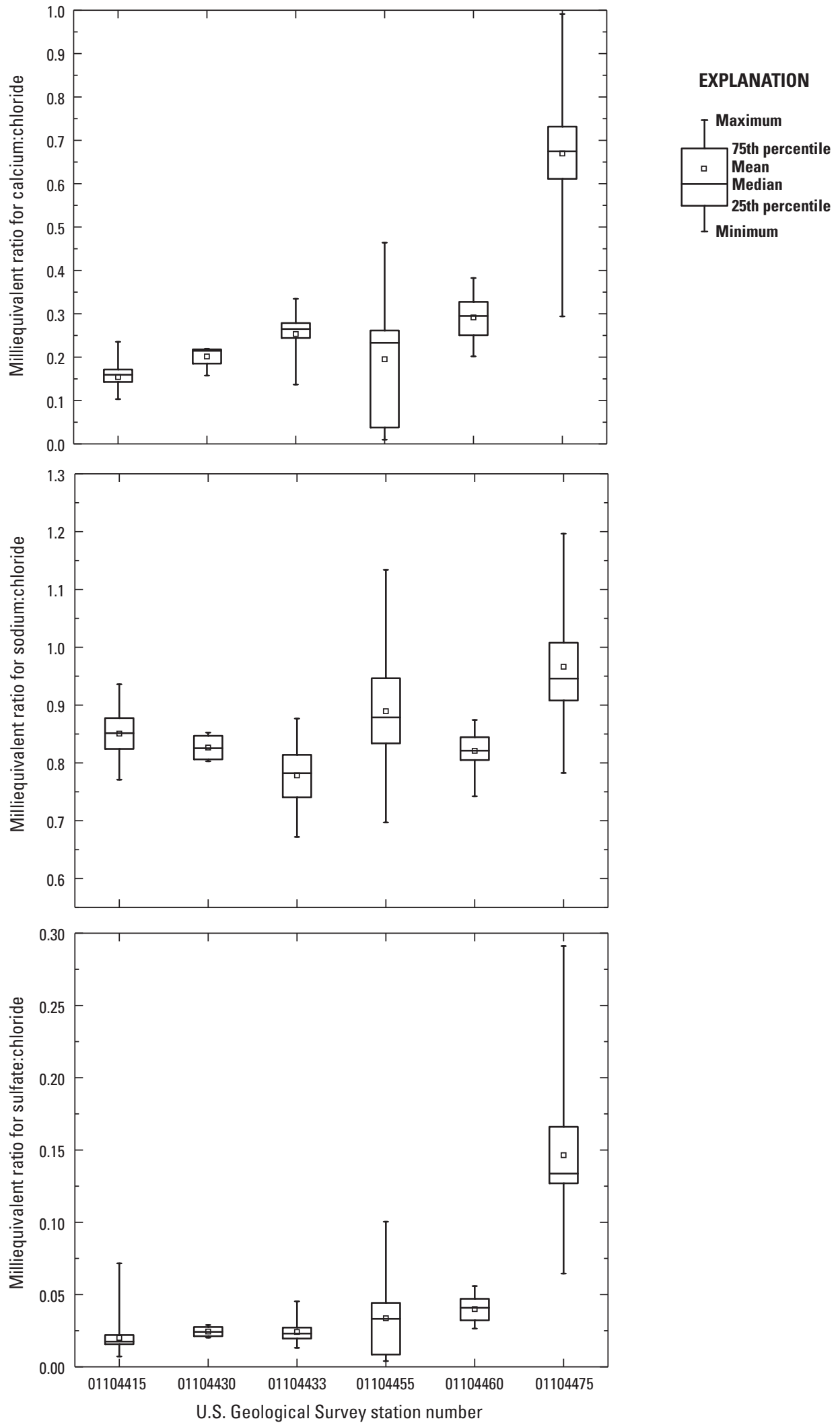

Figure 6. Milliequivalent ratios of calcium, sodium, and sulfate to chloride in sample populations from six U.S. Geological Survey monitoring stations in the Cambridge drinking-water source area, Massachusetts, water years 2004-08. 


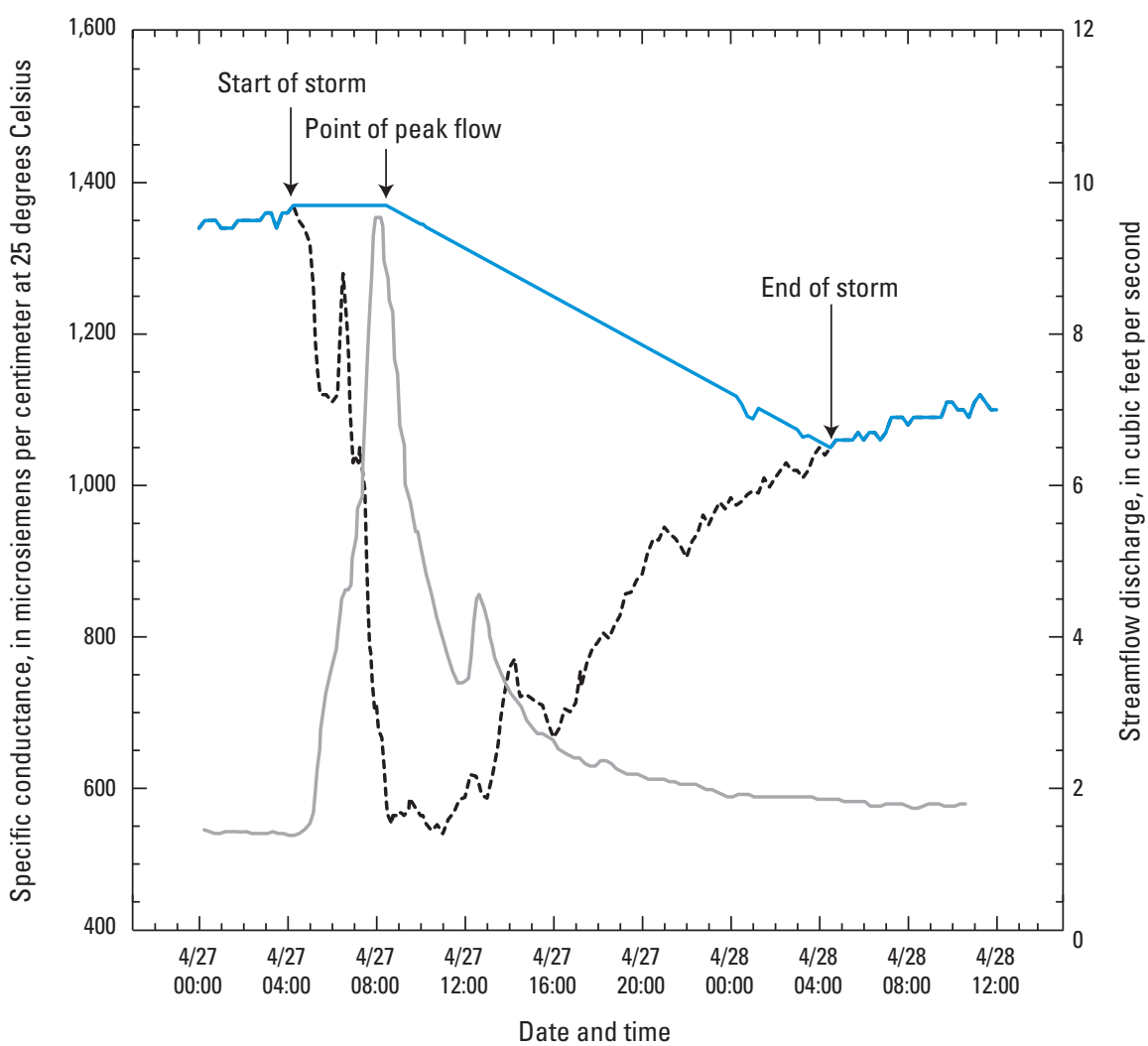

Figure 7. Example of separation of baseflow and stormflow specific conductance at U.S. Geological Survey station 01104415, Cambridge drinking-water source area, Massachusetts, water year 2007.

\section{Determination of Trends}

Time trends in concentrations or loads of water-quality constituents can indicate long-term changes in streamwater quality. Statistical tests to identify time trends were performed for annual loads of $\mathrm{Cl}$ and $\mathrm{Na}$ estimated from records of flow and specific conductance at USGS monitoring stations 01104430 and 01104460 for water years 1998 to 2008. Trend tests were not performed on similar data at other monitoring stations within the drinking-water source area nor were tests performed on nutrient and pesticide data because the length of record (about 3 years) was insufficient to produce reliable results from the test. Trends for each constituent at each USGS station were analyzed by using the seasonal Mann-Kendall test (Helsel and Hirsch, 2002). A trend was considered significant if the $\mathrm{p}$ value was less than or equal to 0.05 .

\section{Water-Quality Conditions}

Summary statistics for measured properties (temperature, $\mathrm{pH}$, specific conductance, and dissolved oxygen concentration) and the chemical composition of water in the Cambridge drinking-water source area were compared to water-quality criteria and used to describe water-quality conditions. In addition, factors, such as land use, that potentially affect water quality are discussed in this section. Summary statistics, including the minimum, mean, median, maximum, and the standard deviation for each constituent are provided in table 7 for the five primary sampling stations and the rawwater intake at the Fresh Pond Reservoir and in table 8 for base-flow samples collected at secondary sampling stations (Smith 2008 and 2011).

Because median values are less influenced by high or low concentrations (or outliers), they are more appropriate descriptors of data that are not normally distributed than are mean values. Medians are especially useful for summarizing small datasets, such as the data for the secondary sampling stations. However, mean values are generally more appropriate for characterization of loads as discussed earlier.

\section{Water Properties}

Water-quality properties include specific conductance, dissolved oxygen concentration, $\mathrm{pH}$, and turbidity. These properties are general indicators of water-quality conditions and can be used to identify site-specific issues. Available statistics for each property are summarized in tables 7 and 8 for the study period. 


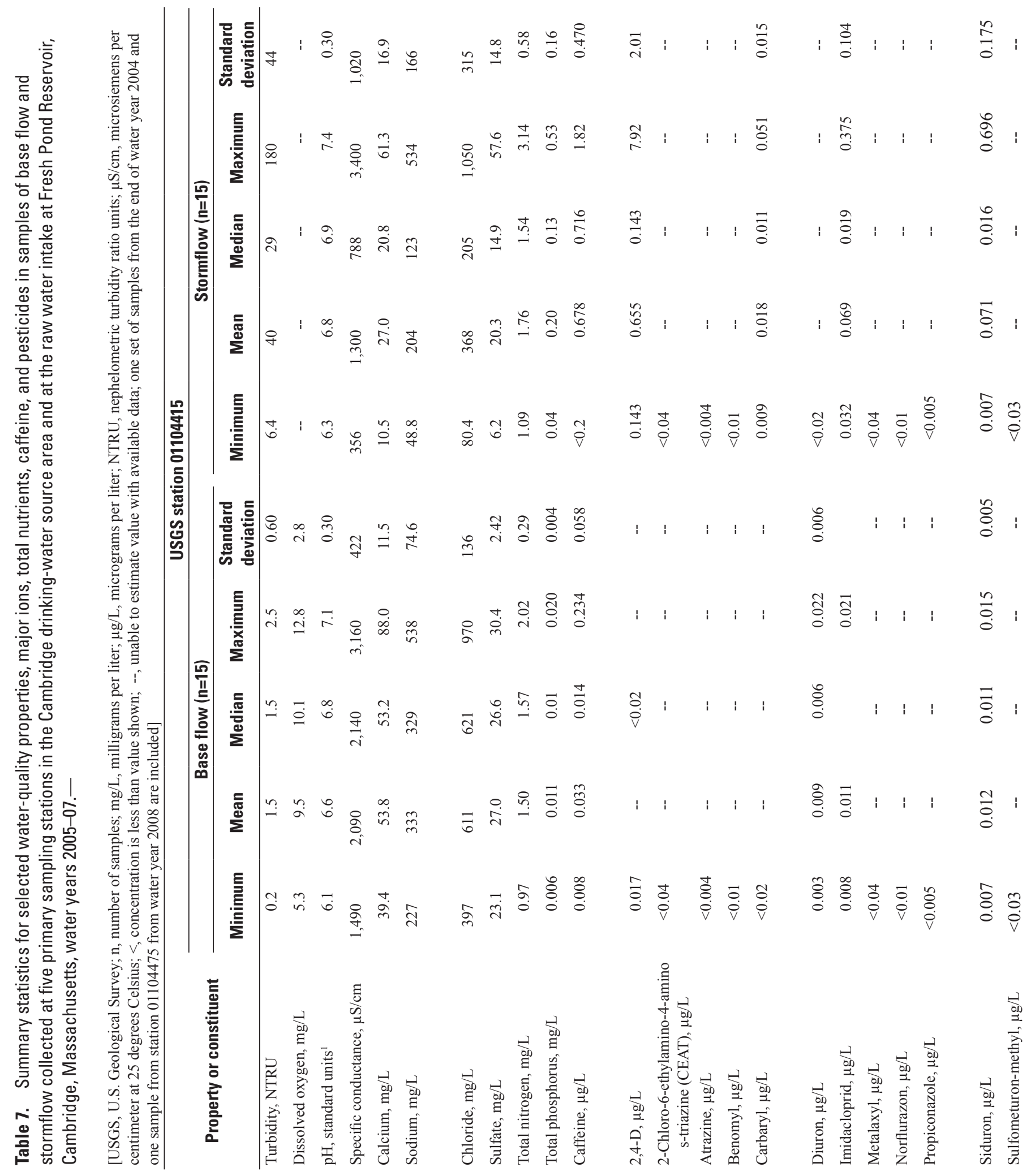




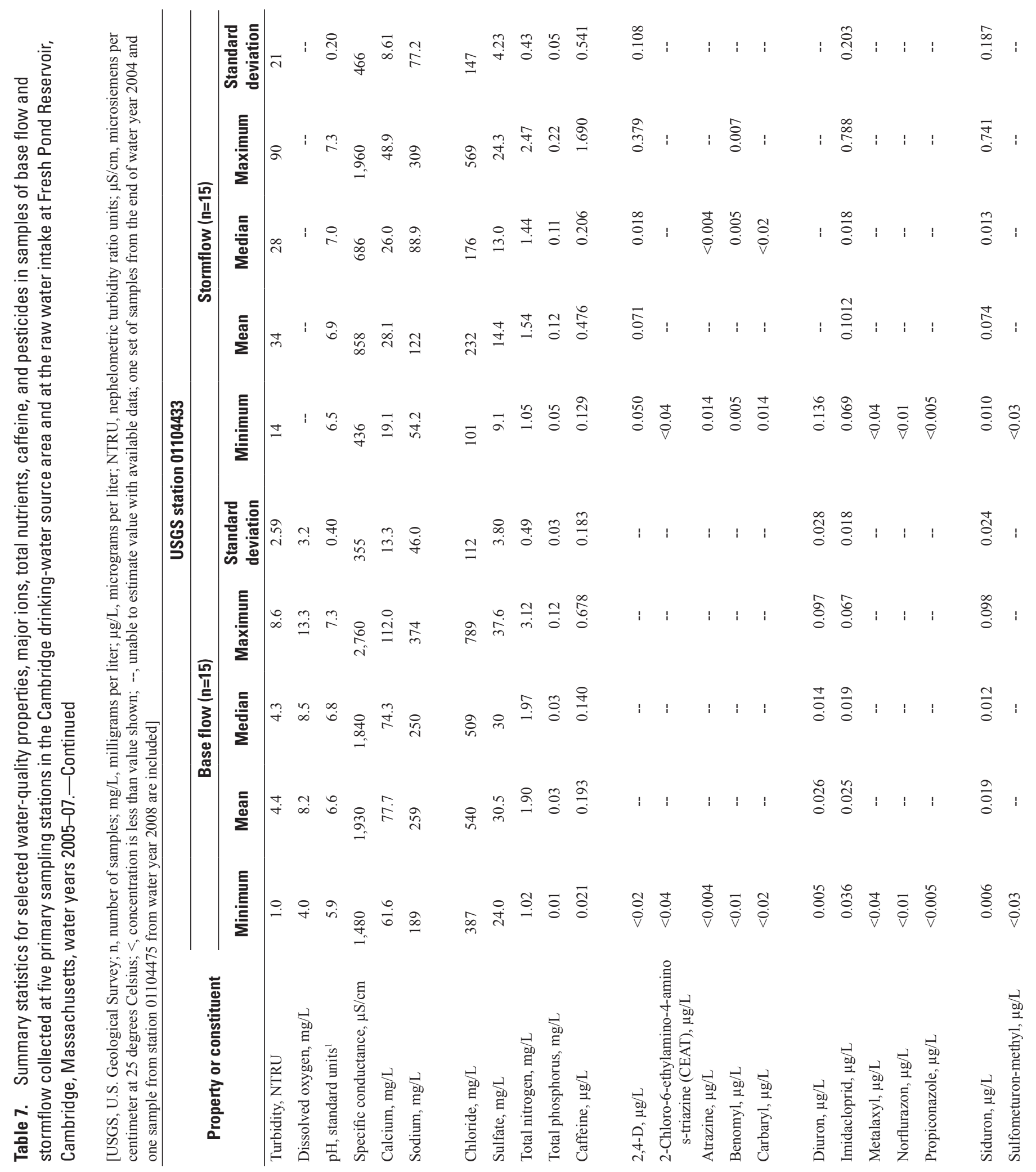




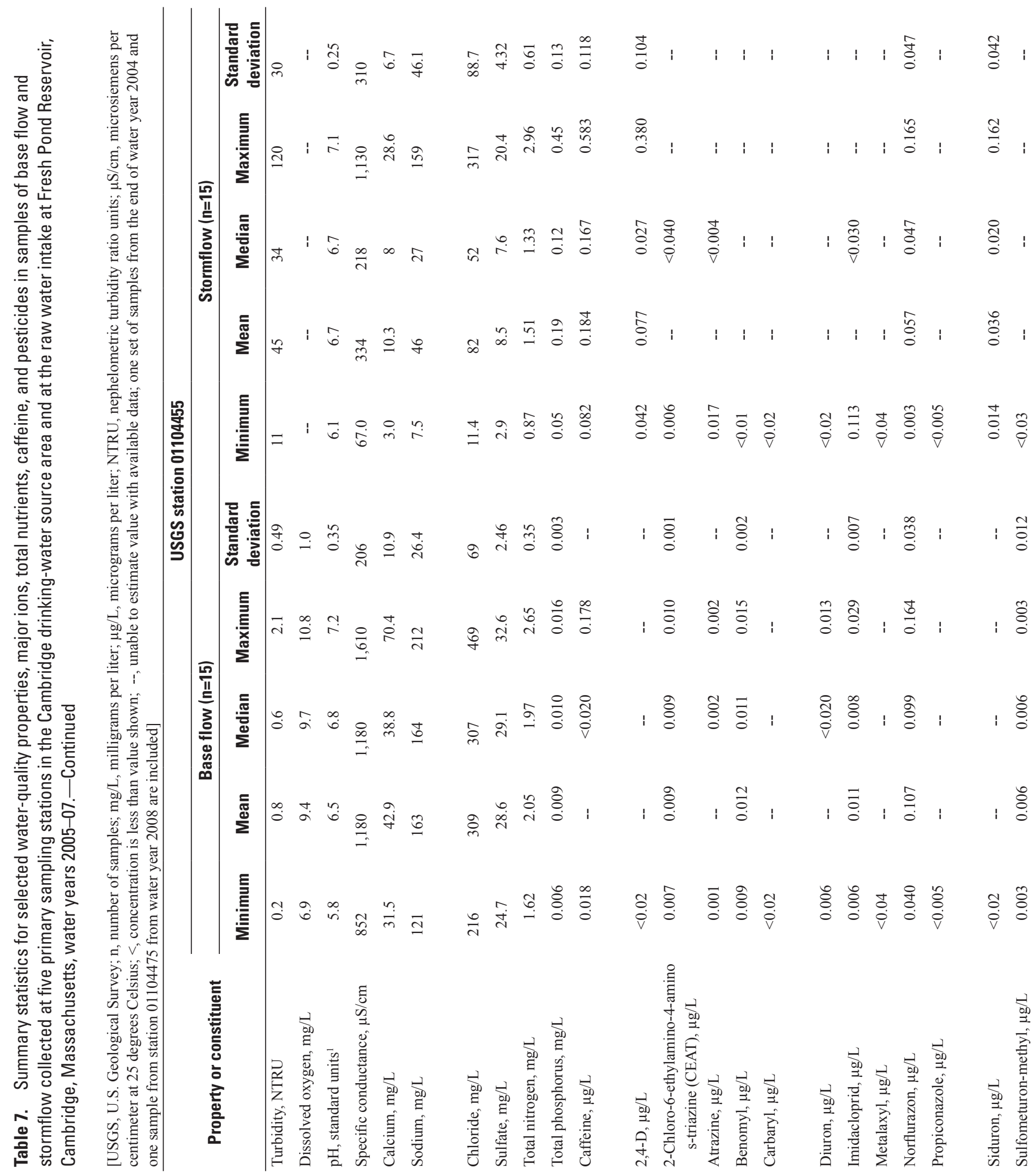




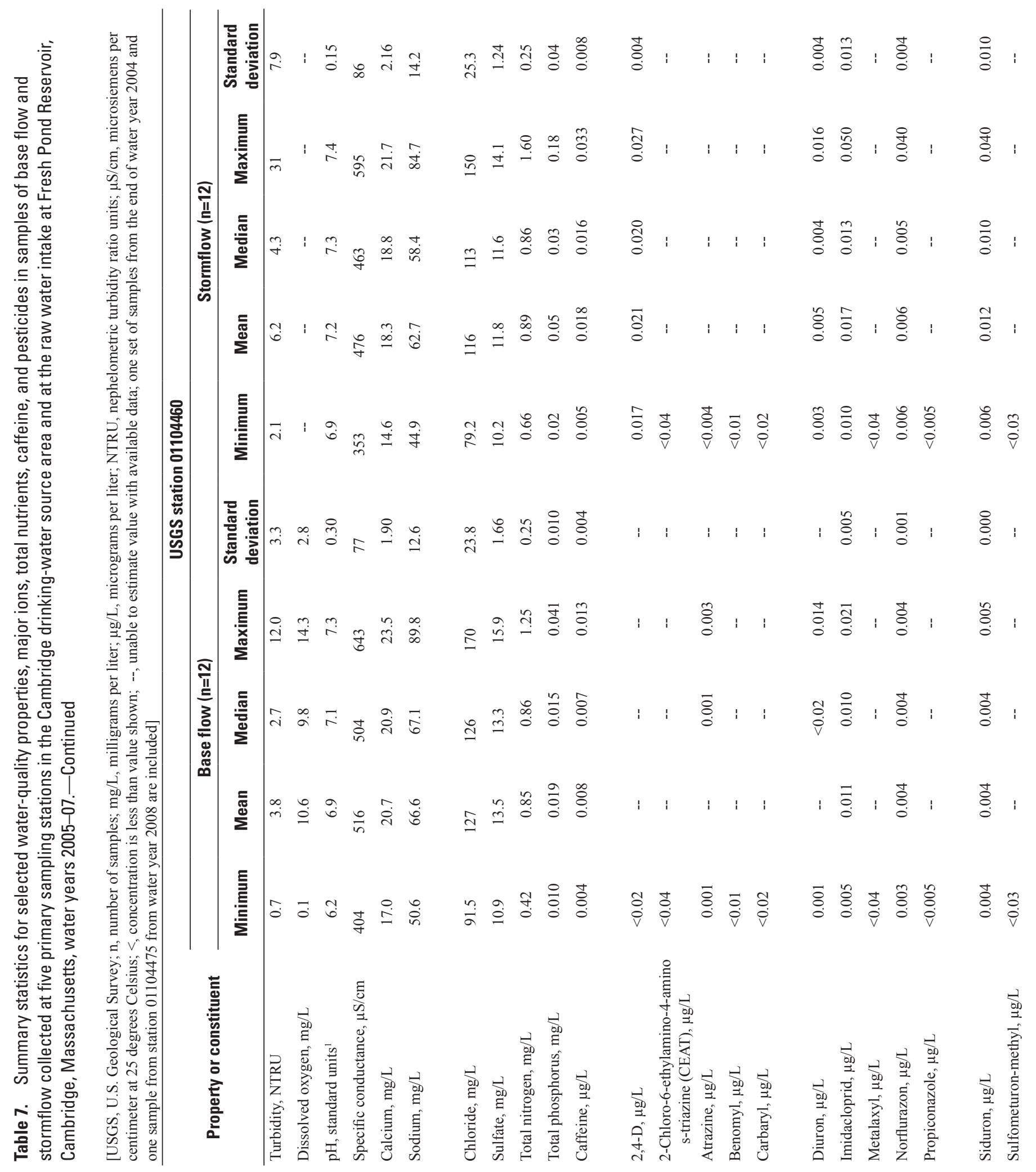




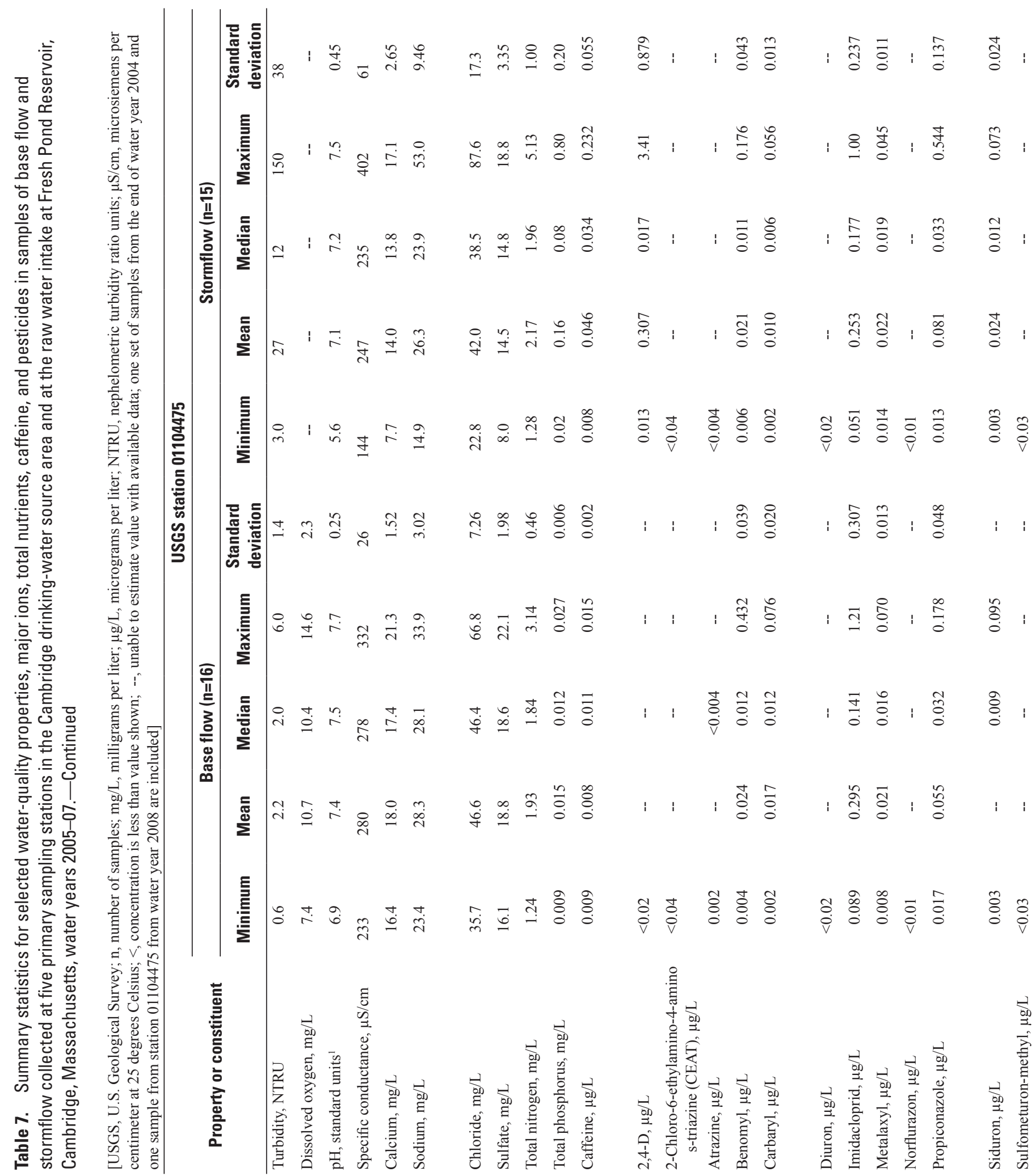




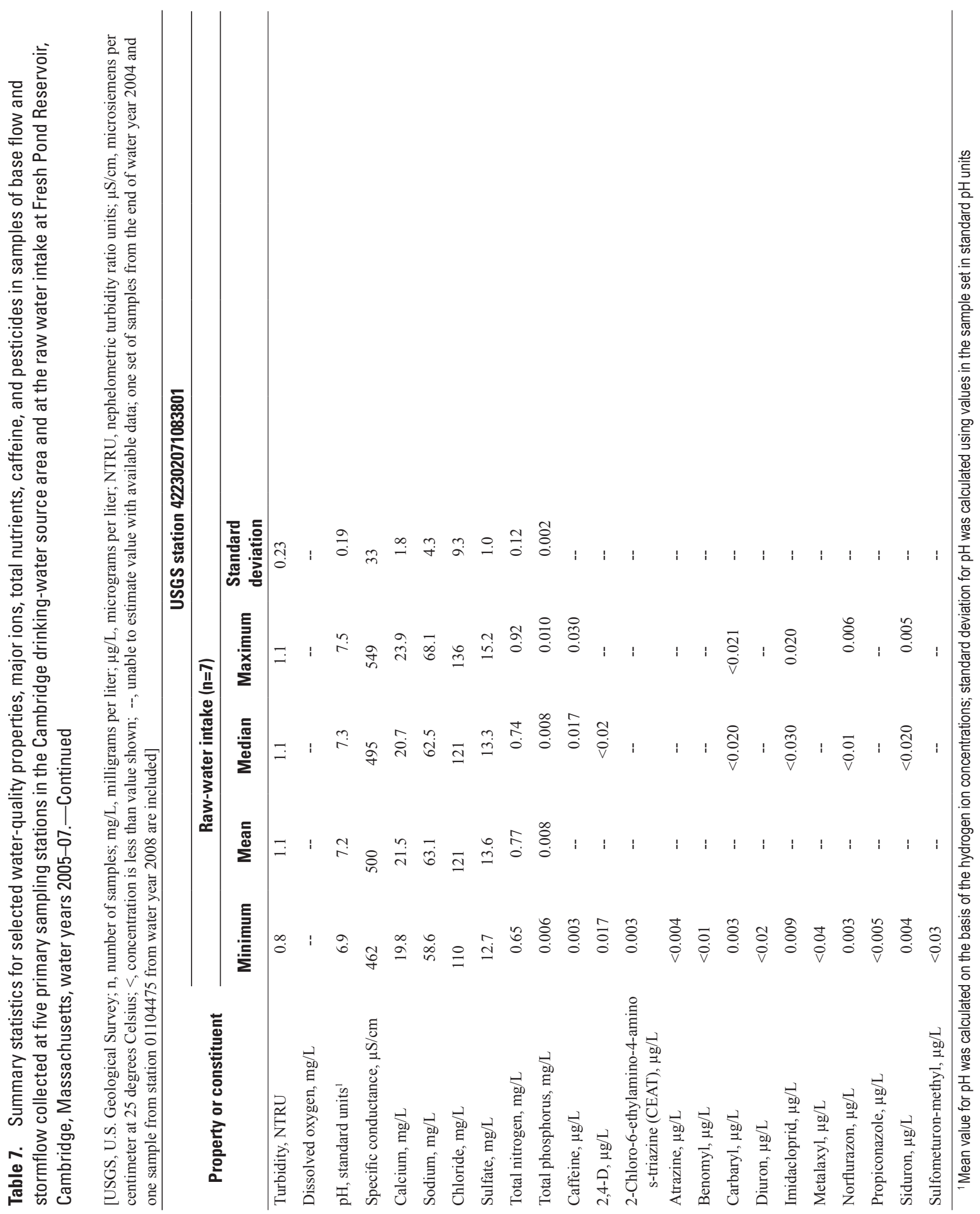




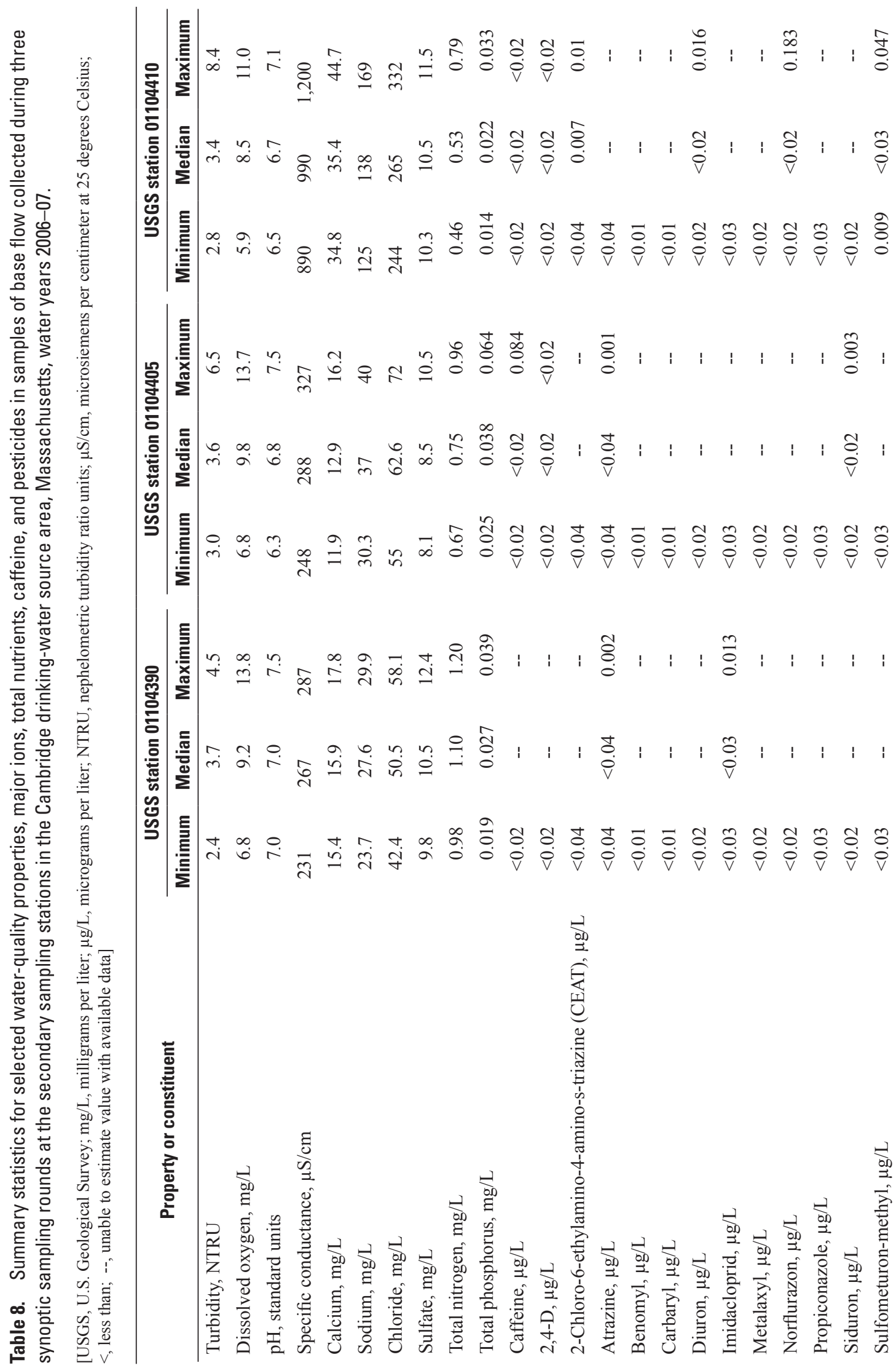




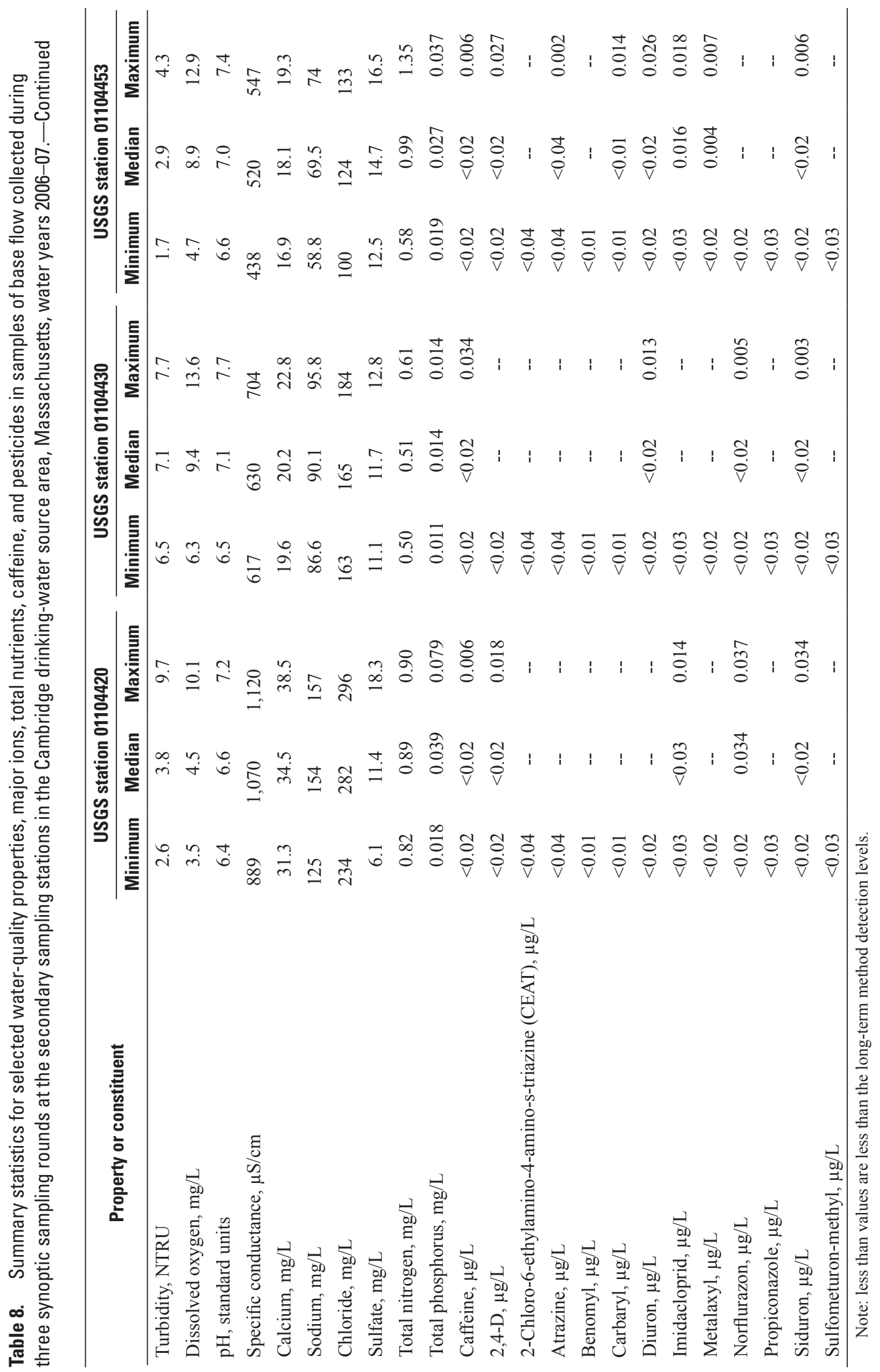




\section{Specific Conductance}

Specific conductance is the measure of the capacity of water to conduct an electrical current. The conductance of water is affected by the type and quantity of ions in water. Specific conductance was measured in samples of base flow and composite samples of stormflow; specific conductance also was continuously recorded using in situ monitors at the primary sampling stations (fig. 1) in the Cambridge drinkingwater source area.

Specific conductance measured in water samples collected throughout the study period at all USGS monitoring stations ranged from 67 to $3,400 \mu \mathrm{S} / \mathrm{cm}$. In contrast, recorded values of specific conductance, which included many more measurements obtained over a wide range of flow conditions, ranged from 13 to $98,500 \mu \mathrm{S} / \mathrm{cm}$ for the same period (Smith, 2005, 2007, 2008, and 2011). In-situ measurements of specific conductance in water released from the Cambridge Reservoir (USGS station 01104430) ranged from about 290 to $1,700 \mu \mathrm{S} / \mathrm{cm}$. In-situ measurements of specific conductance in the main stem of Stony Brook (USGS station 01104460) ranged from 35 to $3,420 \mu \mathrm{S} / \mathrm{cm}$, although these values were generally between about 400 and $650 \mu \mathrm{S} / \mathrm{cm}$. Because the quantity and quality of water in the tributaries respond rapidly to stormwater runoff, discrete in-situ measurements of specific conductance for USGS stations 01104415,01104433 , and 01104455 on the tributaries often differed by several orders of magnitude from the annual mean values at each station (Smith 2005, 2007, 2008, and 2011). The specific conductance during base flow at these tributaries was typically greater than $1,000 \mu \mathrm{S} / \mathrm{cm}$; however, specific conductance during runoff events ranged by as much as two orders of magnitude in either direction. USGS stations 01104415 and 01104455 on two tributaries that parallel Interstate 95 had the greatest range in measured values. The range of in-situ measurements of specific conductance in the tributary to the Stony Brook Reservoir (USGS streamgage 01104475) that flows through a residential area had the smallest range of measured values (40-3,540 $\mu \mathrm{S} / \mathrm{cm})$. Annual means of specific conductance for this station $(248-326 \mu \mathrm{S} / \mathrm{cm})$ were among the lowest in the drinking-water source area. Median values of specific conductance in water samples collected at USGS stations 01104390 , 01104405, 01104410, 01104430, and 01104405 ranged from 267 to $990 \mu \mathrm{S} / \mathrm{cm}$ (table 8 ). Measurements of specific conductance in water samples collected at USGS streamgage 01104420 ranged from 889 to $1,120 \mu \mathrm{S} / \mathrm{cm}$ (table 8 ). Coincidently, the impervious area at this streamgage was greater than 20 percent (table 2 ).

\section{Dissolved Oxygen}

Dissolved oxygen concentration is the amount of gaseous oxygen dissolved in water. Oxygen enters water by diffusion from the surrounding air, aeration from stream turbulence, and photosynthesis. Solubility in water decreases as temperature increases. Dissolved oxygen is necessary for the survival and growth of many aquatic organisms. Dissolved oxygen concentration measured during the collection of base-flow samples ranged from 3.5 to $14.6 \mathrm{mg} / \mathrm{L}$ in the drinking-water source area with a median concentration of $9.6 \mathrm{mg} / \mathrm{L}$. With few exceptions, concentrations of dissolved oxygen typically were greater than $6.0 \mathrm{mg} / \mathrm{L}$. Low concentrations of dissolved oxygen generally occurred in the small tributaries during lowflow conditions in the summer months.

\section{$\mathrm{pH}$}

Measurements of $\mathrm{pH}$ represent the negative base- 10 $\log$ hydrogen-ion concentration, or activity. $\mathrm{pH}$ values near 7 are considered neutral, below 7 are acidic, and above 7 are alkaline or basic. The $\mathrm{pH}$ of river water generally ranges from about 6.5 to 8.5 (Hem, 1992). The $\mathrm{pH}$ of water affects the solubility and biological availability of various chemical constituents, such as nutrients and metals. The $\mathrm{pH}$ of the stream and reservoir waters also affects water-treatment procedures. The $\mathrm{pH}$ of streamwater samples collected from the drinkingwater source area as part of this study ranged from 5.6 to 7.7 and had a median $\mathrm{pH}$ of 7.0. Most $\mathrm{pH}$ values were within a range of 6.5 to 7.4. The $\mathrm{pH}$ of water samples collected from the main stem of Stony Brook (USGS station 01104460; table 7), the largest stream in the watershed, ranged from 6.8 to 7.4, except for one measurement of 6.2 made in water year 2005 (Smith, 2007).

\section{Turbidity}

Turbidity is a measure of the scattering and absorption of light caused by suspended materials (such as silt, clay, and fine organic particles) and dissolved materials that produce color. Turbidity was measured in base-flow and stormflow samples. Turbidity values for all samples collected within the drinkingwater source area ranged from 0.2 to 180 nephelometric turbidity ratio units (NTRUs) with a median of 4.5 NTRUs. Typically, composite samples of stormflow collected at stations in the smaller subbasins (USGS stations 01104415, 01104433, 01104455, and 01104475) had the highest turbidity (table 7).

\section{Constituents}

Concentrations of major ions, total nutrients, caffeine, and pesticides were measured in base-flow and stormflow samples collected at 11 sampling stations in the Cambridge drinking-water source area. These data were used to establish baseline conditions, to identify areas of concern, and to assess overall water quality and compliance with Federal and State guidelines. Concentrations of these constituents are summarized for the study period. 


\section{Major lons}

The major ions, $\mathrm{Ca}, \mathrm{Cl}, \mathrm{Na}$, and $\mathrm{SO}_{4}$ are commonly found in natural waters at concentrations greater than $1.0 \mathrm{mg} / \mathrm{L}$ (Hem, 1992) and are of special concern in the Cambridge drinking-water source area (Smith, 2007) because they are not readily removed by conventional treatment processes. High concentrations of $\mathrm{Cl}$ in drinking water can affect the taste of finished drinking water, and high concentrations of $\mathrm{Na}$ contribute to hypertension in susceptible individuals (U.S. Environmental Protection Agency, 2009b). Although $\mathrm{Ca}, \mathrm{Cl}, \mathrm{Na}$, and $\mathrm{SO}_{4}$ are common in precipitation (National Atmospheric Deposition Program, 2008), minerals and soils in the environment (Hem, 1992; Smith, 2005), septic effluent, industrial wastes, and wastewater (Mullaney and others, 2009), these elements also are major constituents of road salt and other deicing compounds used within the drinking-water source area. Deicing compounds readily dissolve, and associated ions are transported to nearby streams by surface runoff and groundwater discharge. Considering the large amounts of impervious area and numerous roadways in the drinkingwater source area (fig. 1 and table 2), deicing compounds are a potentially important source of these ions.

Concentrations of $\mathrm{Ca}, \mathrm{Cl}, \mathrm{Na}$, and $\mathrm{SO}_{4}$ in base-flow samples and stormflow composite samples varied widely among the tributaries in the drinking-water source area (tables 7 and 8). Concentrations of these ions in water samples collected at USGS stations 01104415,01104433 , and 01104455 , on tributaries with large amounts of impervious area in their drainage basins, varied by several orders of magnitude. The median concentrations for $\mathrm{Ca}, \mathrm{Cl}, \mathrm{Na}$, and $\mathrm{SO}_{4}$ in samples collected in the Hobbs Brook Basin were 39.8, 392, 207, and $21.7 \mathrm{mg} / \mathrm{L}$, respectively, whereas median concentrations in samples from the tributaries in the Stony Brook Reservoir watershed were lower at 17.8, 87.7, 49.7, and 14.7 mg/L, respectively. Median major ion concentrations in samples from the main stem of Stony Brook (USGS station 01104460), the primary stream discharging to the Stony Brook Reservoir, were 19.5, 126, 65.8 , and $12.4 \mathrm{mg} / \mathrm{L}$, respectively, indicating high-concentration waters from the Cambridge Reservoir watershed were diluted by inflow from tributaries draining the larger and overall less urbanized Stony Brook Reservoir watershed.

Mean annual flow-weighted concentrations for $\mathrm{Ca}, \mathrm{Cl}$, $\mathrm{Na}$, and $\mathrm{SO}_{4}$ estimated from records of specific conductance and flow at USGS station 01104430, at the outlet of the Cambridge Reservoir, for water years 2004 to 2008 were 21.5, 186, 101, and $15.3 \mathrm{mg} / \mathrm{L}$, respectively. However, mean annual flow-weighted concentrations of these ions at Stony Brook (USGS station 01104460), estimated in the same manner and for the same period, were lower at 18.2,111, 60.4, and $11.3 \mathrm{mg} / \mathrm{L}$, respectively. Mean annual flow-weighted concentrations for $\mathrm{Ca}, \mathrm{Cl}, \mathrm{Na}$, and $\mathrm{SO}_{4}$ at USGS station 01104475, on the only other tributary that flows directly into the Stony Brook Reservoir (fig. 1), were 15.4, 41.6, 25.7, and $15.8 \mathrm{mg} / \mathrm{L}$, respectively.

\section{Total Nutrients}

Nutrients, such as nitrogen $(\mathrm{N})$ and phosphorus $(\mathrm{P})$, are essential to the health and diversity of aquatic organisms. Biological and chemical processes can mobilize each nutrient to or from the soil, reservoir sediments, water column, atmosphere, and organisms. Algae and aquatic plants consume various species of each nutrient until limited by their availability. In the reservoirs in the drinking-water source area, $\mathrm{P}$ was determined to be the limiting nutrient (Waldron and Bent, 2001). Thus, high concentrations of $P$ in the reservoirs can result in overgrowth of plant life, algal blooms, reduction in oxygen levels, and decline or shift in the biological community.

Common sources of $\mathrm{P}$ include weathering of natural rocks and soils, fertilizers, and leaking or failing septic tanks. In general, $\mathrm{P}$ is somewhat insoluble and tends to be associated with sediment and plant matter (Smith, 2002; Smith, 2005; Breault and others, 2005). As a result, erosion of local soils and even application of sand to roads and parking lots during winter maintenance activities (Smith and Granato, 2010) can increase TP concentrations in receiving waters. Common sources of nitrogen $(\mathrm{N})$ are precipitation, nitrogen emissions from automobiles, degradation of natural organic matter, fertilizers, leaking sewer lines, and failing septic tanks. In a recent highway runoff study (Smith and Granato, 2010), the $\mathrm{TN}$ content in precipitation was estimated to account for about 55 percent of the mean concentration of TN in all samples of highway runoff collected at monitoring stations along Interstate 95 near the Cambridge Reservoir. Although waterfowl are often considered a source of both nutrients, a previous USGS study (Waldron and Bent, 2001) estimated that less than 0.1 percent of the total input of $\mathrm{N}$ into the reservoirs was derived from waterfowl.

The concentration of TN in water samples from all subbasins ranged from 0.42 to $5.13 \mathrm{mg} / \mathrm{L}$ (tables 7 and 8). The median concentration for $\mathrm{TN}$ in all samples collected in the Hobbs Brook Basin was $1.48 \mathrm{mg} / \mathrm{L}$, and the median concentration in the samples from tributary streams in the Stony Brook Reservoir watershed was $1.52 \mathrm{mg} / \mathrm{L}$. Mean concentrations of TN in samples of base flow and stormflow collected at the primary sampling stations on the four tributaries ranged from 1.63 to $2.05 \mathrm{mg} / \mathrm{L}$. The mean concentration of TN in samples of base flow and stormflow collected at USGS station 01104460, the main stream to the Stony Brook Reservoir, was $0.87 \mathrm{mg} / \mathrm{L}$.

The concentration of TP in water samples for all subbasins ranged from 0.006 to $0.80 \mathrm{mg} / \mathrm{L}$ (tables 7 and 8). The median concentration for TP in all samples collected in the Hobbs Brook Basin was about $0.04 \mathrm{mg} / \mathrm{L}$, whereas the median concentration in the tributaries in the Stony Brook Reservoir watershed was $0.03 \mathrm{mg} / \mathrm{L}$. Mean concentrations of TP in samples of base flow and stormflow collected at the primary sampling stations on the four tributaries ranged from 0.09 to $0.12 \mathrm{mg} / \mathrm{L}$. The mean concentrations of TP in samples of base flow and stormflow collected at USGS station 01104460, the 
main stream to the Stony Brook Reservoir, was $0.03 \mathrm{mg} / \mathrm{L}$. The low mean concentration of TP for this station is potentially the result of dilution of higher concentrations in stormflows by reservoir water containing base-flow level concentrations of TP; reservoir water is continuously released from the Cambridge Reservoir upstream.

\section{Pesticides and Caffeine}

Pesticides are commonly used by homeowners to control nuisance plants, fungi, and insects in homes and gardens. Pesticides, including herbicides, fungicides, and insecticides are used to increase the production in home gardens, prevent structural damage, eliminate unwanted weeds and brush, and protect lawns and ornamental plants. Many pesticides also are used on golf courses and other recreational areas, and on roadway right-of-ways (Racke, 1993). During 2006-07, over 70 million pounds of pesticides were purchased in the United States for use in the home and garden (Fishel, 2011). As a result of widespread use, pesticides are frequently detected in groundwater and surface water in urbanized areas (Gilliom and others, 2006; U.S. Geological Survey, 1999).

The potential for a pesticide to reach receiving water bodies is a function of its physical properties, including aqueous solubility, tendency to adsorb to soils, and environmental persistence. Additionally, many of these properties are affected by the organic carbon content, $\mathrm{pH}$, alkalinity, and temperature of soil and water (Hornsby and others, 1996). In general, pesticides with low aqueous solubility, long aerobic soil half life, moderate to long aqueous half life, and low soil sorption values have the potential to infiltrate and move though groundwater (Vogue and others, 1994). Pesticides that are strongly absorbed to soils are unlikely to be transported in a dissolved state; however, such compounds can be transported with soil to receiving tributaries in runoff.

Caffeine is present in the seeds and leaves of more than 60 plant species and in a variety of beverages, food products, and pharmaceuticals (Burge and others, 2003). Caffeine is commonly detected in streams and rivers throughout the United States and is a generally considered an indicator of wastewater contamination (Lawrence and LaFontaine, 2010; Zaugg and others, 2007; Sando and others, 2005). Caffeine generally exists in the dissolved phase in many watersheds (Burge and others, 2003), thus sorption and sedimentation of the compound in the drinking-water supply is likely negligible. The detection of caffeine in base-flow samples, where streamflow is dominated by groundwater discharge, may indicate the presence of domestic (septic-system) or municipal (leaking sewer lines) wastewater (Seiler and others, 1999). Caffeine is also present in stormwater runoff from roadways and parking areas where caffeinated beverages were spilled or caffeine-laden litter is present. In a recent highway runoff study (Smith and Granato, 2010), caffeine was routinely detected in samples of stormwater runoff collected from the impervious area of five highways, including two highways that intersect the Cambridge Reservoir and Stony Brook Reservoir watershed (Interstate 95 and Route 2; fig. 1).

Twenty-five pesticides and caffeine were detected in water samples collected at the sampling stations in the Cambridge Reservoir and Stony Brook Reservoir watersheds and in raw water collected at the Cambridge water-treatment facility intake from the Fresh Pond Reservoir during this study. Thirty-four pesticides (table 3 ) were not detected. Most of the detected pesticides are found in over-the-counter products used for turf management and the treatment of ornamental shrubs (table 9). Although many pesticides were detected in the drinking-water source area, only nine compounds were detected at a frequency greater than or equal to 15 percent (table 10); the detection frequency varied substantially from station to station. Summary statistics for concentrations of pesticides that were detected in at least 25 percent of the samples of base flow or stormflow at one or more primary sampling stations are given in table 7; available statistics for the same pesticides detected in base-flow samples collected at the secondary sampling stations are in table 8. Imidacloprid, norflurazon, and siduron were the pesticides most frequently detected (table 10) in samples of water collected in the drinking-water source area; the frequency of detections ranged from about 24 to 42 percent. These compounds are highly mobile and are likely to occur in both stormwater runoff and groundwater inflow to the tributaries as a result of their chemical characteristics (table 9). Imidacloprid, siduron, and 2,4-D were the only pesticides detected in samples collected at all of the primary sampling stations (fig. 1 and table 7); 2,4-D was the most commonly used herbicide in the United States during 2006-07 (Fishel, 2011). The herbicide norflurazon was detected in 90 percent of the samples collected at USGS station 01104455 . The herbicide siduron; the insecticides carbaryl and imidacloprid; and the fungicides benomyl, metalaxyl, and propiconazole were detected in more than 50 percent of the water samples collected under base-flow and stormflow conditions at USGS station 01104475 . The high aqueous solubility of most of these pesticides explains, in part, their presence in base flow and stormflow. In contrast, benomyl is highly persistent in soils, has low solubility, and degrades quickly in water (table 9). As a result of these characteristics, benomyl is not generally found in groundwater; however, benomyl was detected in 81 percent of the samples collected during base-flow conditions at USGS station 01104475 . This may be explained, in part, by the relatively small drainage area $(2.2$ $\mathrm{km}^{2}$ ) upstream from this station; thus, the time of concentration is short (less than a day). Production of benomyl ceased in 2001, and the sale of benomyl products ended in 2002. Remaining benomyl products have expiration dates ranging from January 2006 to January 2009 (U.S. Environmental Protection Agency, 2003). Observed decreases in benomyl concentrations during water years 2004-08 at USGS station 01104475 (Smith 2005, 2007, 2008, 2011) are likely linked to the termination of its manufacture.

In general, the ranges in concentrations of several of the most frequently detected pesticides - 2,4-D, norflurazon, 


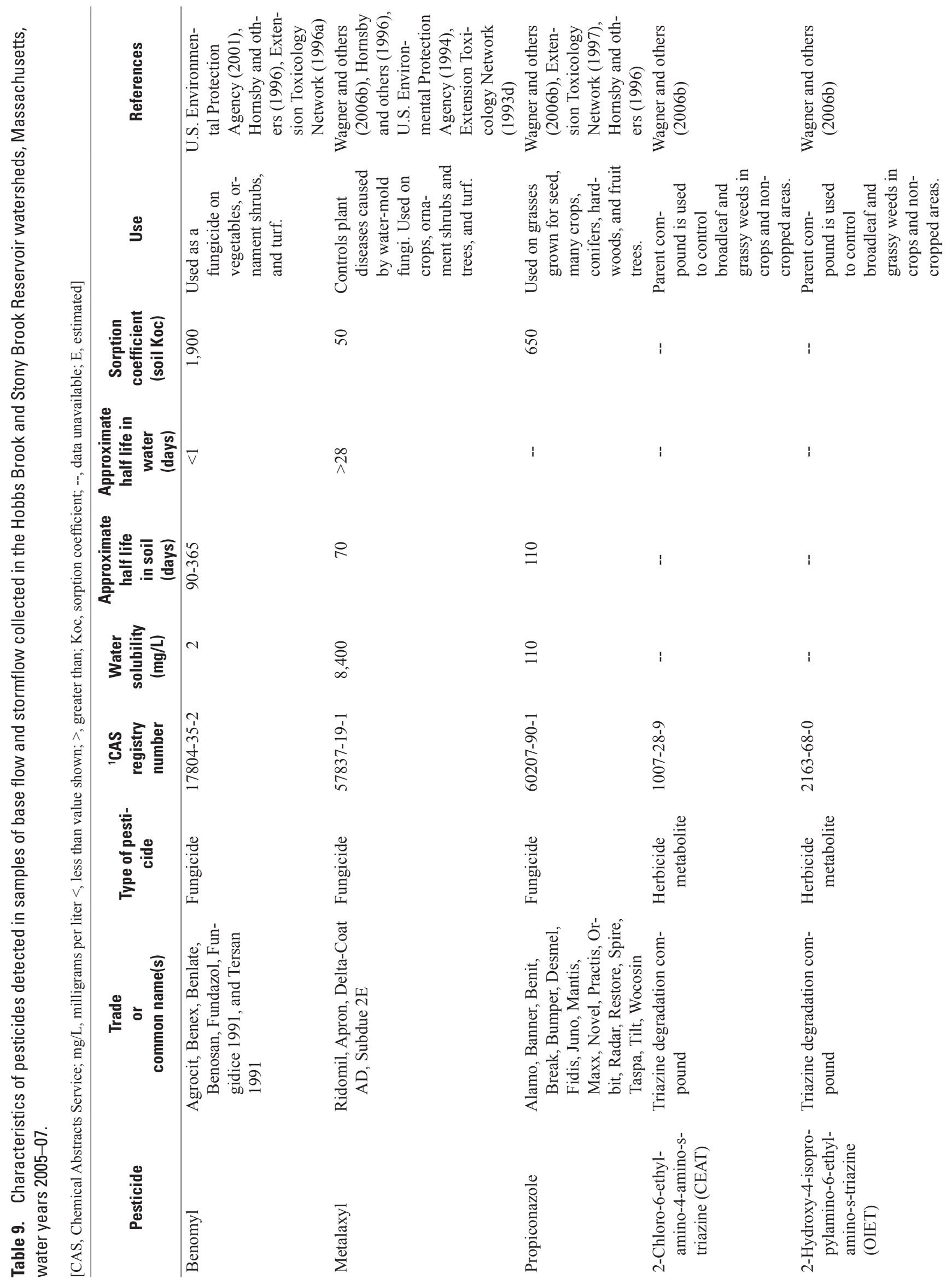




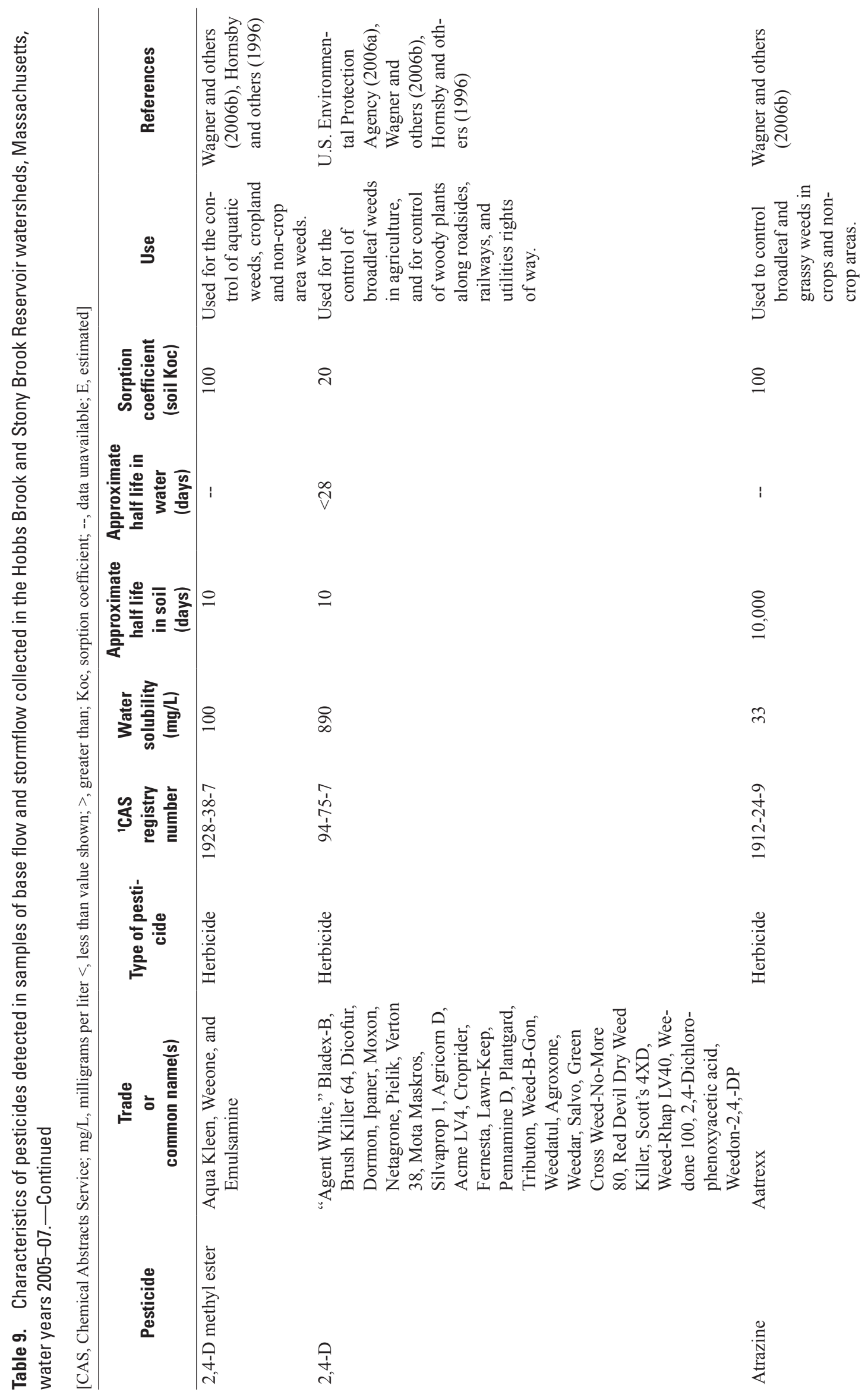




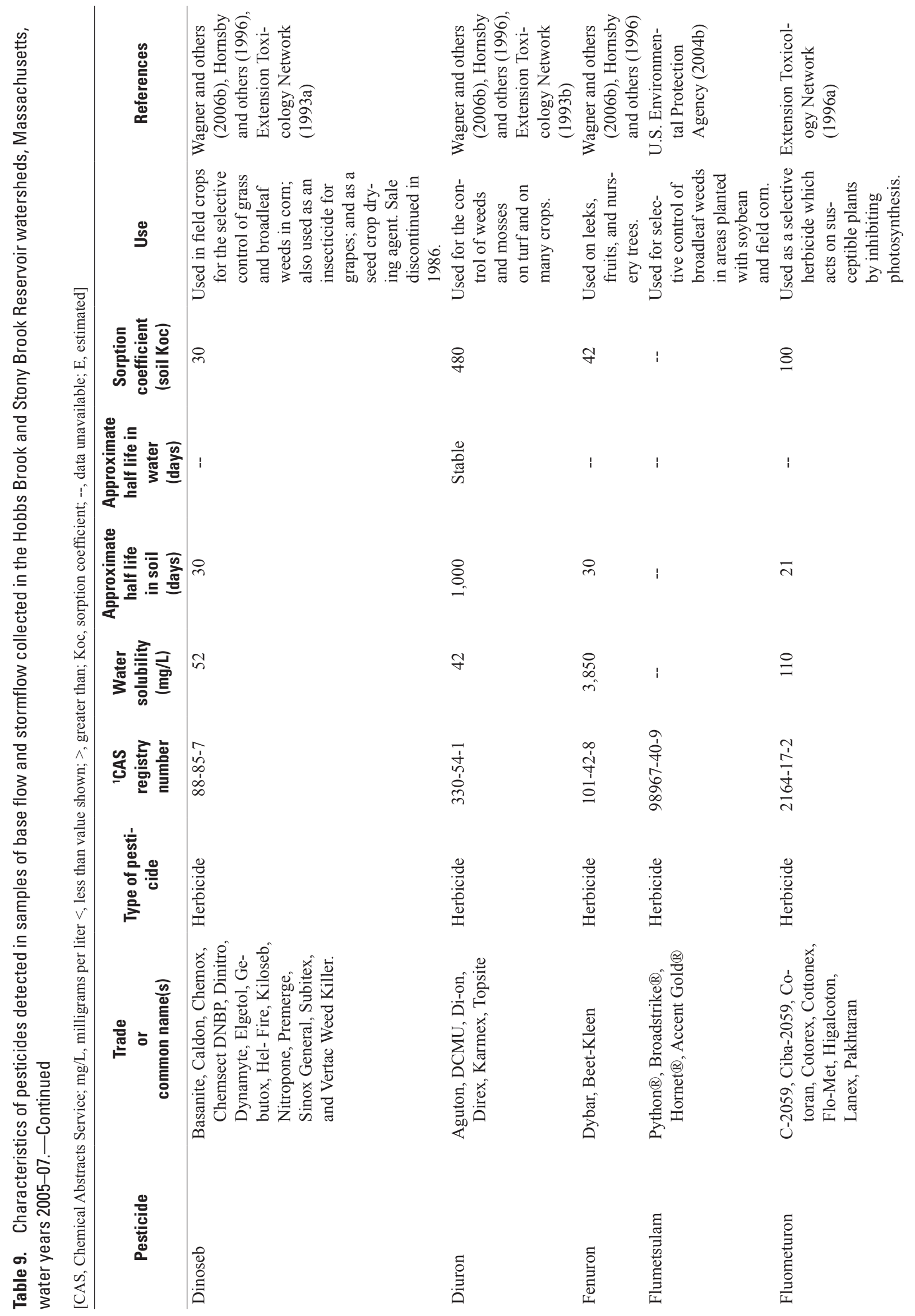




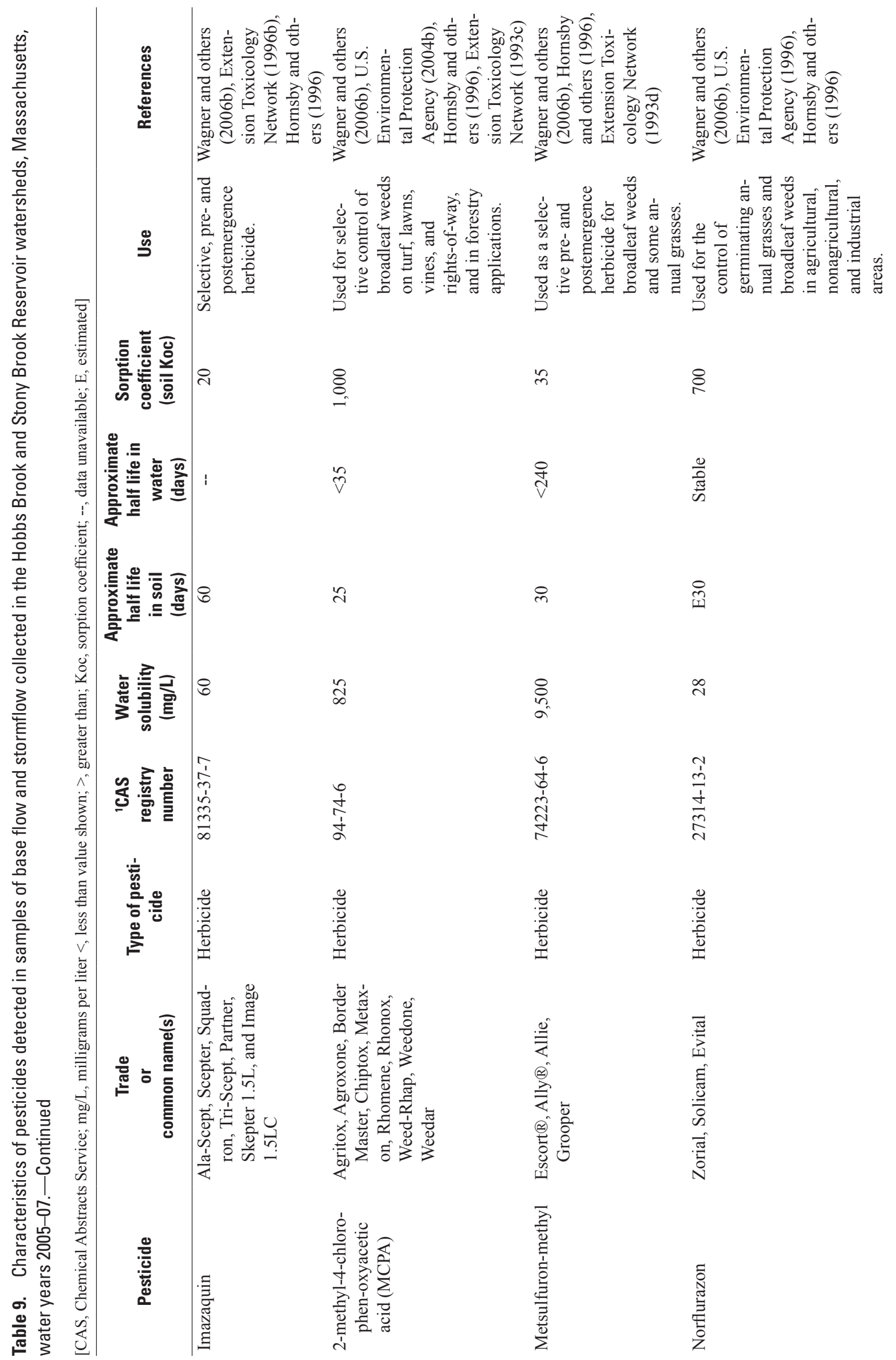




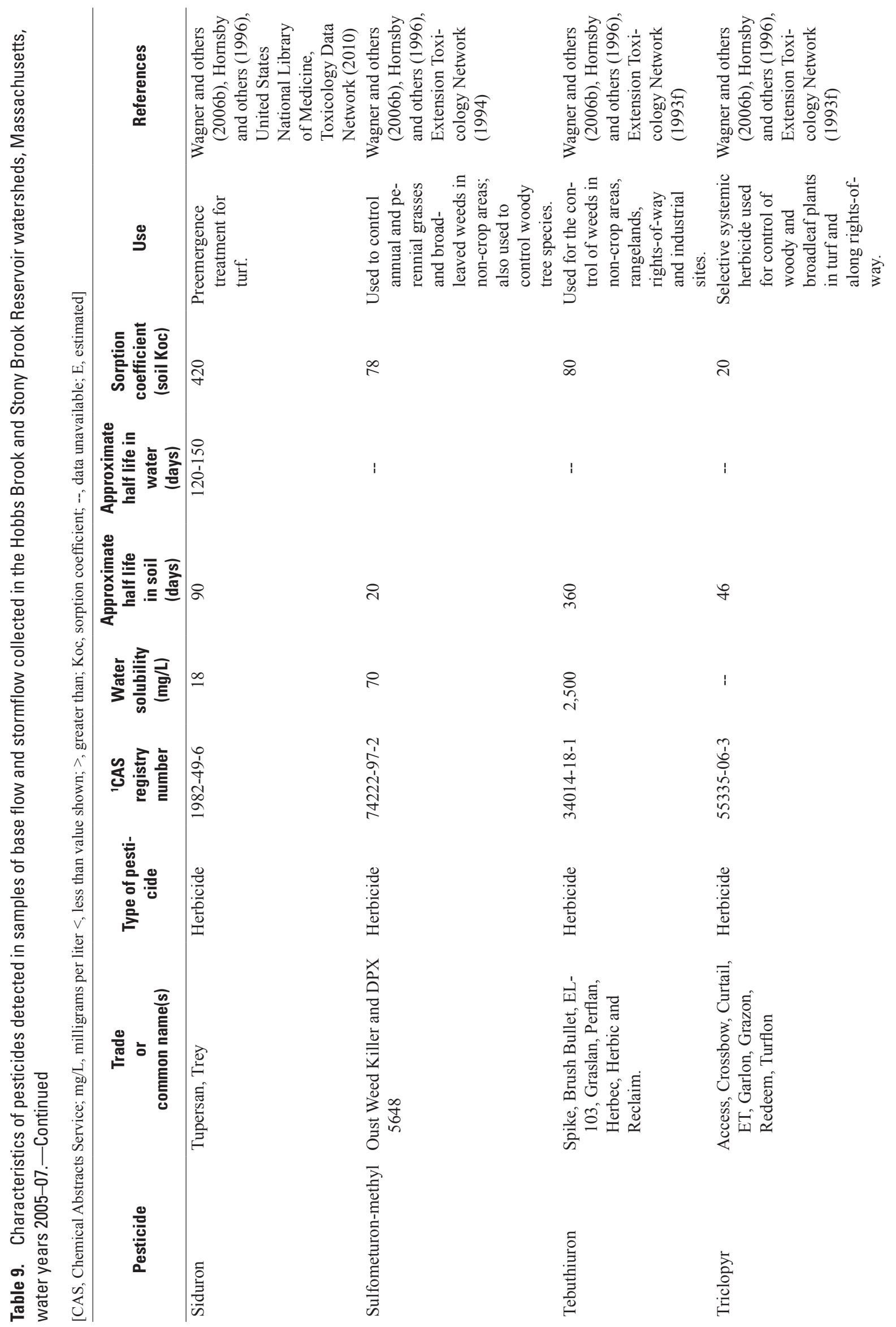




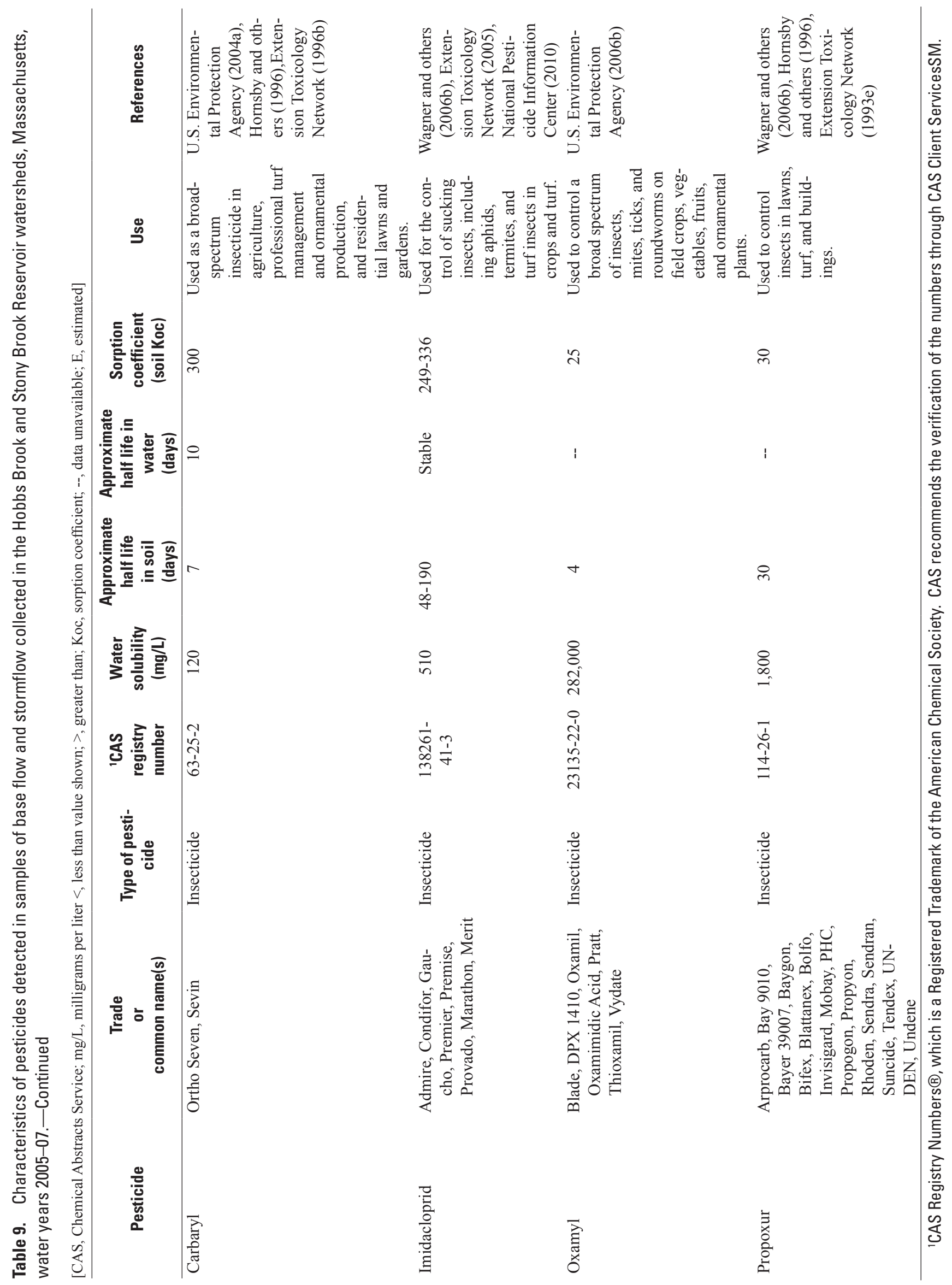




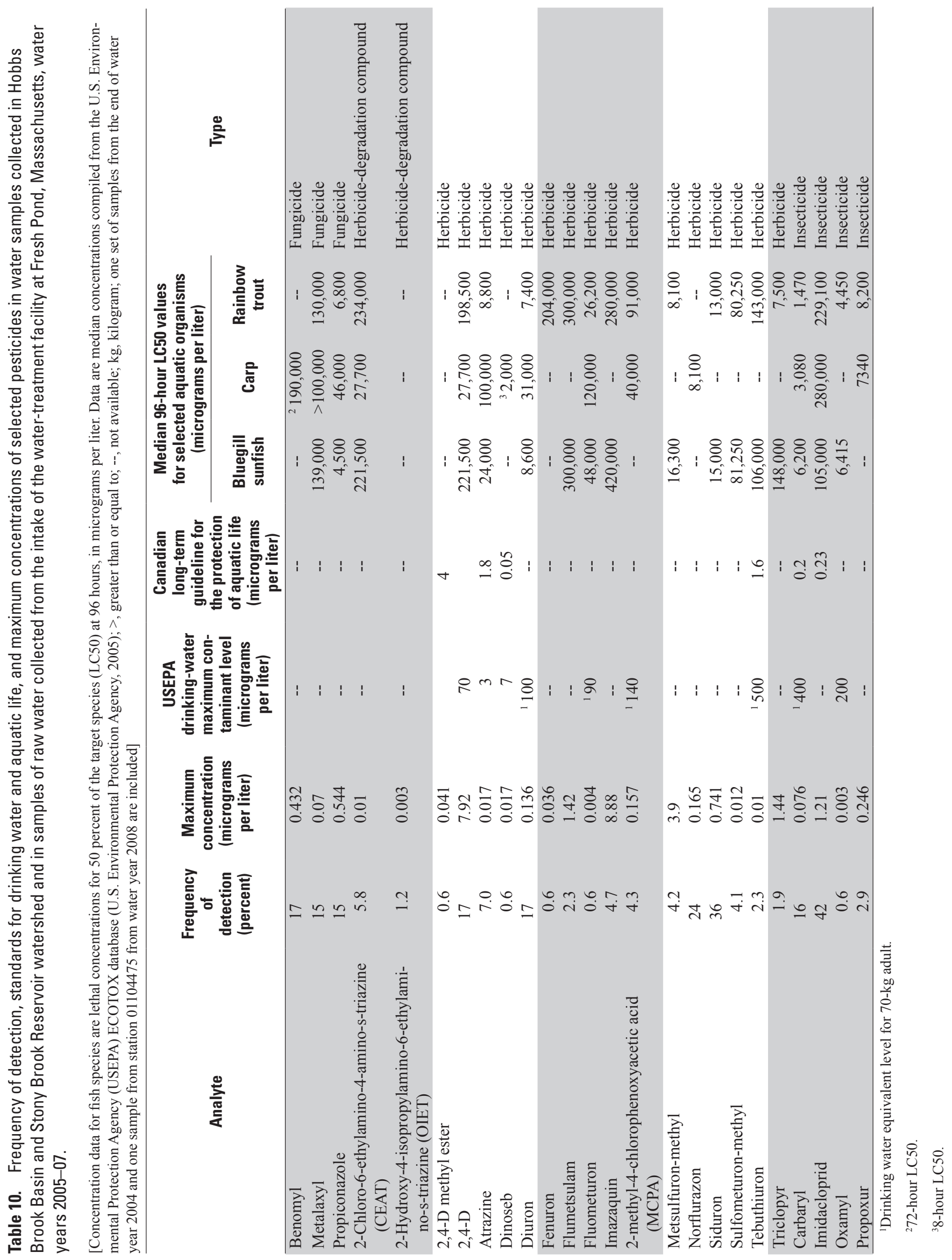


siduron, imidacloprid, carbaryl - and caffeine were similar for the Cambridge Reservoir and Stony Brook watersheds (fig. 8). Diuron concentrations generally were low in the Cambridge Reservoir watershed, and the insecticides benomyl, metalazyl, and propiconazole were not detected in the Cambridge Reservoir watershed. Diuron, norflurazon, and siduron were the only pesticides detected in water samples collected at the outlet of the Cambridge Reservoir (Smith, 2008, 2011). Assuming plug flow where velocity is constant through the reservoir, mean retention time for water in the Cambridge Reservoir during water years 2006-07 was greater than 7 months. As a result, pesticides that have short aqueous half life may degrade within the reservoir. Compounds stable in the aquatic environment, particularly norflurazon and siduron, are able to advance though the entire reservoir system (fig. 8). The mean retention time for the Stony Brook Reservoir is less than about 2 weeks; thus, pesticides with a aqueous half life greater than a week often are able to persist in waters directed to the Fresh Pond Reservoir. Although several pesticides were detected in samples from the Fresh Pond Reservoir raw-water intake (table 7), carbaryl and caffeine, were the only compounds detected at greater than the LTMDL. The presence of carbaryl in samples collected from the raw-water intake may be explained in part by the moderate water solubility and aqueous half life of the compound (table 9) but also may be explained by the proximity of the outfall of a tributary containing elevated concentrations of carbaryl (USGS station 01104475; table 7) to the head of Stony Reservoir. Pesticides were not detected in finished drinking water (Smith, 2005).

Caffeine was detected in about 64 percent of 171 water samples at concentrations ranging from 0.003 to $1.82 \mu \mathrm{g} / \mathrm{L}$ (micrograms per liter; tables 7 and 8 ) and was detected in more than 90 percent of the samples collected at USGS station 01104433. Caffeine was detected in water samples collected at all USGS sampling stations, except for 01104390 and 01104410 .

\section{Factors Affecting Water-Quality Properties and Constituent Concentrations}

The quality of water in the streams and tributaries of the Cambridge drinking-water source area is affected by seasonal streamflow, stormwater runoff, and land-use activities. Streamflow volume, to some extent, correlated with waterquality properties and concentration data. Streamflow volume is affected by storm intensity and duration, seasonal precipitation, and evapotranspiration. Stormwater runoff can mobilize deicing compounds, sediment and associated constituents, and pesticides. In contrast, the addition of stormwater can dilute the concentration of constituents derived from groundwater inflow. The amount and type of land use often determines the types of constituents in tributaries and can affect the pathways by which these constituents reach receiving water bodies.

\section{Seasonal Variability}

Concentrations of many constituents varied throughout the water year. These variations are a function of seasonal climatological processes, as well as seasonal anthropogenic activities, such as the application of deicing compounds and sand during the winter and the application of various pesticides at specific times during the year.

For most sampling stations in the drinking-water source area, concentrations of $\mathrm{Ca}, \mathrm{Cl}, \mathrm{Na}$, and $\mathrm{SO}_{4}$ in samples of tributary water are negatively correlated with the log values of streamflow (table 4). As a result, specific conductance and major ion concentrations in samples at most of the sampling stations tend to increase during the summer when streamflow is low and decrease during high base-flow conditions and periods of stormwater runoff (fig. 9), indicating that groundwater is an important source of many of the major ions. Although initial stormflow during the winter was commonly accompanied by high specific conductance measurements (fig. 9) indicative of high concentrations of $\mathrm{Ca}, \mathrm{Cl}, \mathrm{Na}$, and $\mathrm{SO}_{4}$, the concentrations of these ions in composite samples of stormflow were similar to, and in some cases lower than, concentrations in samples of base flow (table 7).

Concentrations of TP were positively correlated with flow, especially during storms, and the relation was statistically significant at three of the five primary sampling stations (USGS stations 01104415, 01104433, and 01104455). Positive correlations between concentrations and streamflow typically occur when a constituent is strongly associated with suspended sediment. When the concentration of suspended sediment increases, as it generally does following rainfall, the concentrations of constituents associated with or sorbed to the suspended sediment also increases. Phosphorus is present in streambed sediment, as well as in local soil adjacent to the tributaries in the drinking-water source area (Smith, 2005). In contrast, the correlation between TN concentration and streamflow was poor, indicating that streamflow explains little of the observed variability in the TN concentrations. This lack of correlation is likely the result of similarities between concentrations of TN in precipitation and in groundwater inflows. Flow-weighted annual concentrations of $\mathrm{TN}$ in precipitation in the study area during water years 2005-07 were about 1 mg/L (National Atmospheric Deposition Program, 2008), whereas mean concentrations of TN in base-flow samples ranged from 1.24 to $2.05 \mathrm{mg} / \mathrm{L}$ (table 7) at USGS stations 01104415, 01104433, 01104455, and 01104475. Additional N from fertilizers, automobile emissions, and natural and other anthropogenic sources, combined with precipitation runoff, further reduces the difference in concentrations of TN between groundwater inflow and stormflow.

Many pesticides are applied once or more a year and, therefore, might be expected to have seasonal patterns of concentrations in streamwater. However, many of the pesticides were detected throughout the year in both base-flow and stormflow samples collected in the drinking-water source area. The frequent detection of many of the pesticides might 


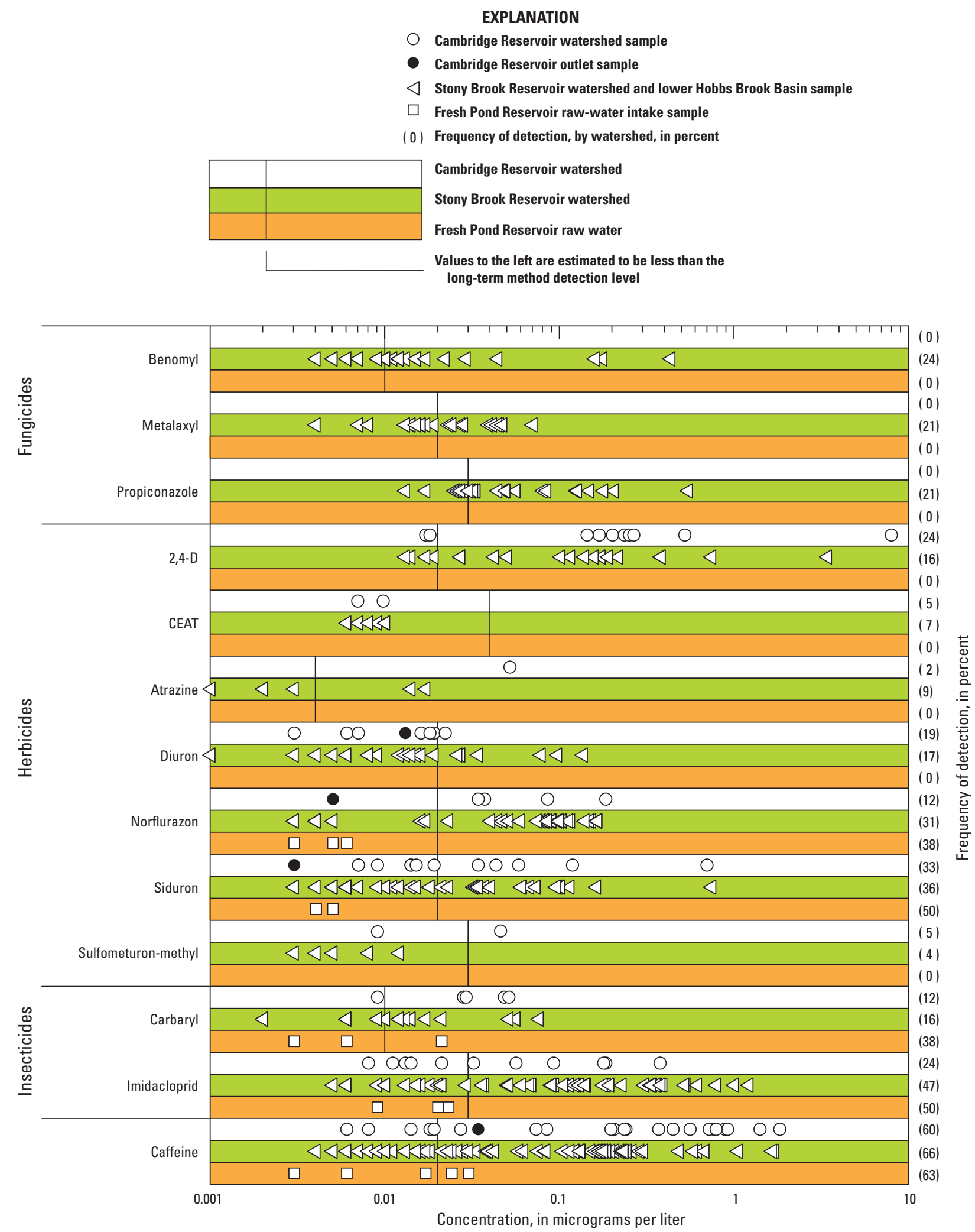

Figure 8. Concentrations of selected pesticides and caffeine detected in samples of water collected during base flow and stormflow at all monitoring stations in the Cambridge drinking-water source area and from the Fresh Pond Reservoir rawwater intake, Cambridge, Massachusetts, water years 2004-08. 


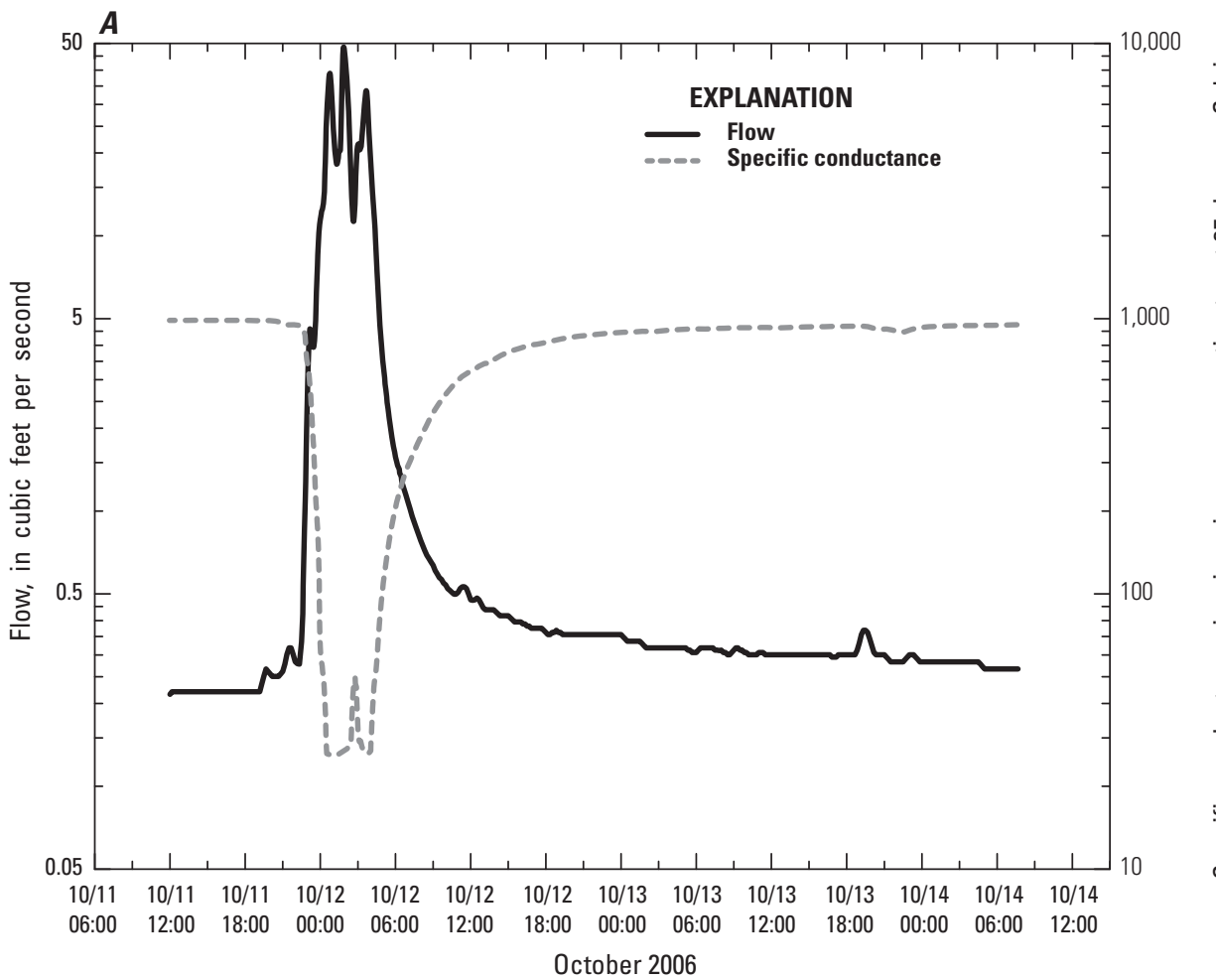

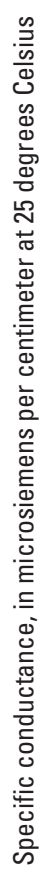

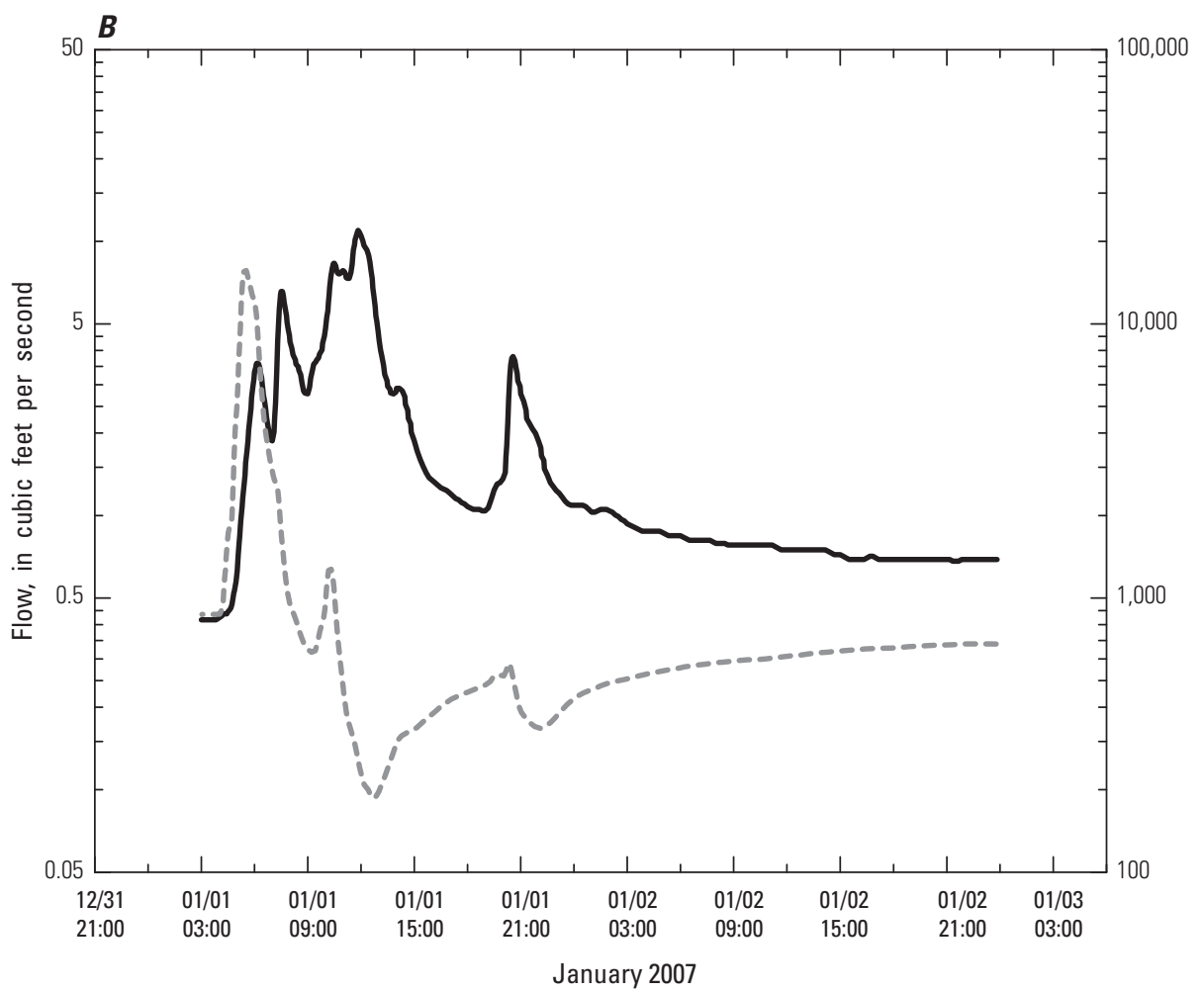

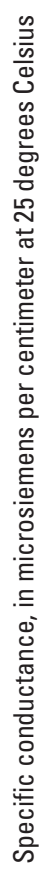

Figure 9. Records of flow and specific conductance during $A$, fall and $B$, winter storm runoff at U.S. Geological Survey station 01104455, Stony Brook Reservoir watershed, Massachusetts, water year 2007. 
be related to chemical properties (high solubility, long aqueous half life, and low soil sorption values) that allow the compounds to infiltrate groundwater and to the range in transport time between the location of application and the distance to the stream.

\section{Stormwater runoff}

Results for Mann-Whitney tests indicate that some values of water-quality properties and concentrations of major ions and nutrients in base flow were significantly different from those in composite samples of stormflow (table 7). The turbidity values for stormflow samples were higher than those for base-flow samples at four of the five primary sampling stations (fig. 10), and at three stations, the entire range of turbidity values for stormflow samples exceeded the range of turbidity values for base-flow samples. In many cases, the mean and median values of turbidity for the stormflow samples from the tributaries were an order of magnitude higher than the respective values for base-flow samples (table 7).

Concentrations of TP were higher in stormflow samples than in base-flow samples. The interquartile range of TP concentrations in stormflow samples from the primary sampling stations exceeded the interquartile range of TP concentrations in base-flow samples. In contrast, the concentrations of major ions in composite stormflow samples generally were less than concentrations of major ions in base-flow samples, indicating the effects of dilution from stormflow (table 7; figs. 11-12). Concentrations of TN in base flow and stormflow, although more variable in stormflow samples, were generally similar (table 7 and fig. 13). The pesticides 2,4-D, carbaryl, imazaquin, MCPA, metsulfuron-methyl, norflurazon, and siduron, some of which have large soil sorption coefficients (table 9) and weakly absorb to soil, were more frequently detected in stormflow samples than in base-flow samples (fig. 14). Caffeine was detected in about 96 percent of all stormflow samples compared to about 44 percent for base-flow samples.

\section{Land Use}

The land use and associated constituents in a watershed often affect the water quality, especially those constituents introduced through anthropogenic activities. Comparisons of concentrations of selected constituents to percentages of landuse areas can provide water-resources managers with information useful for establishing drainage-area-protection strategies, such as the purchase of land and restrictions on certain land uses. Explicit use of alternative deicing compounds, such as calcium chloride, to reduce $\mathrm{Na}$ concentrations in receiving water is an example of one such restriction.

A correlation analysis was performed for mean annual flow-weighted concentrations of $\mathrm{Ca}, \mathrm{Cl}, \mathrm{Na}, \mathrm{SO}_{4}, \mathrm{TN}, \mathrm{TP}$,

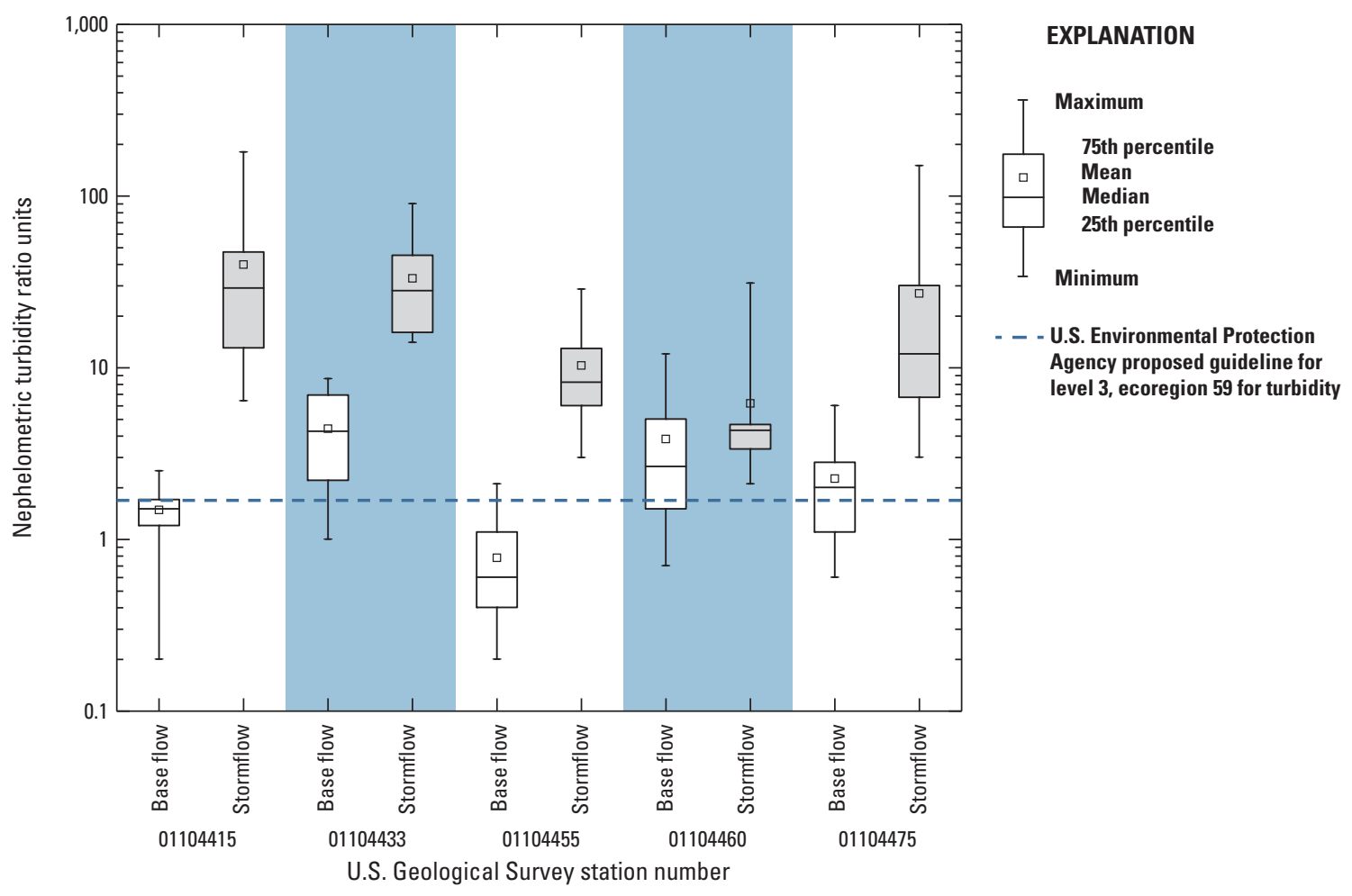

Figure 10. Distributions of turbidity in base-flow and stormflow samples collected from five U.S. Geological Survey stations in the Cambridge drinking-water source area, Massachusetts, water years 2005-07. 


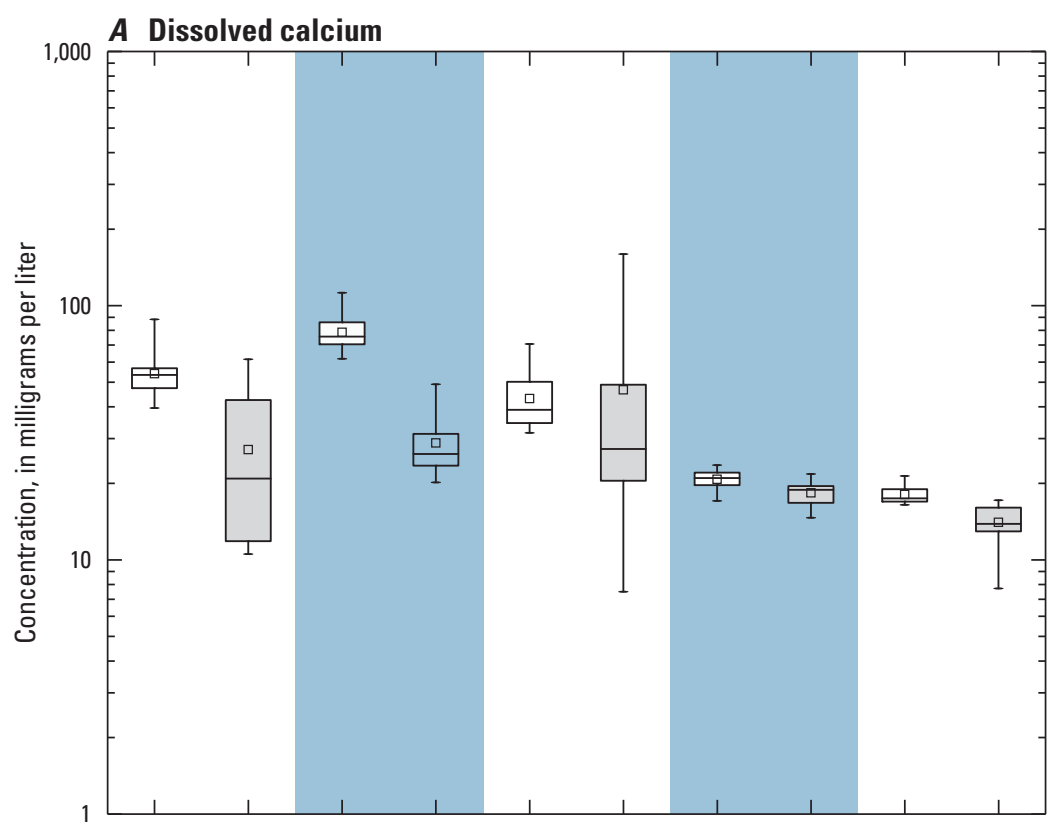

\section{EXPLANATION}
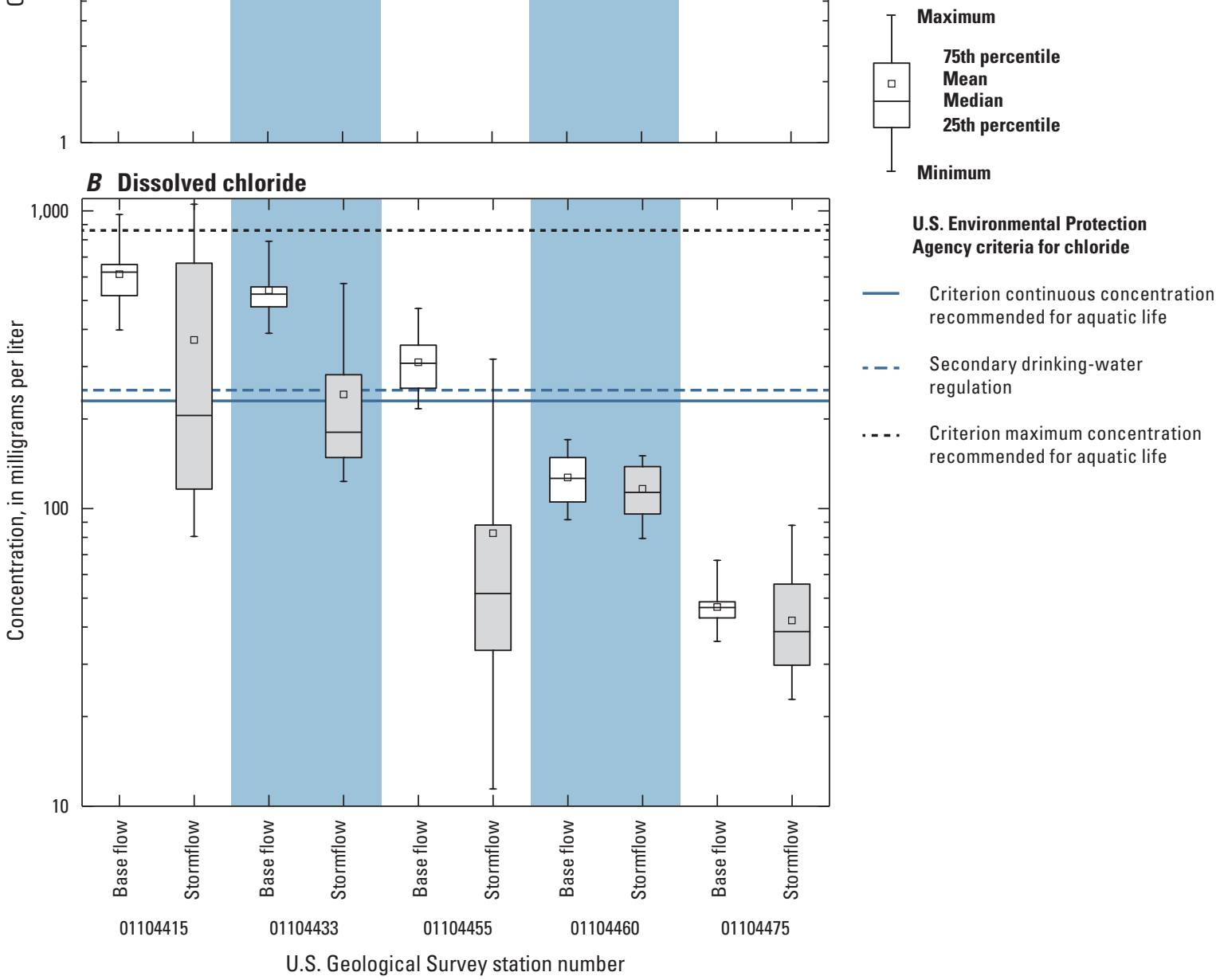

Figure 11. Distributions of concentrations of $A$, dissolved calcium and $B$, chloride in base-flow and stormflow samples from five U.S. Geological Survey stations in the Cambridge drinking-water source area, Massachusetts, water years 2005-07. [U.S. Environmental Protection Agency, 2007; U.S. Environmental Protection Agency, 2009a] 


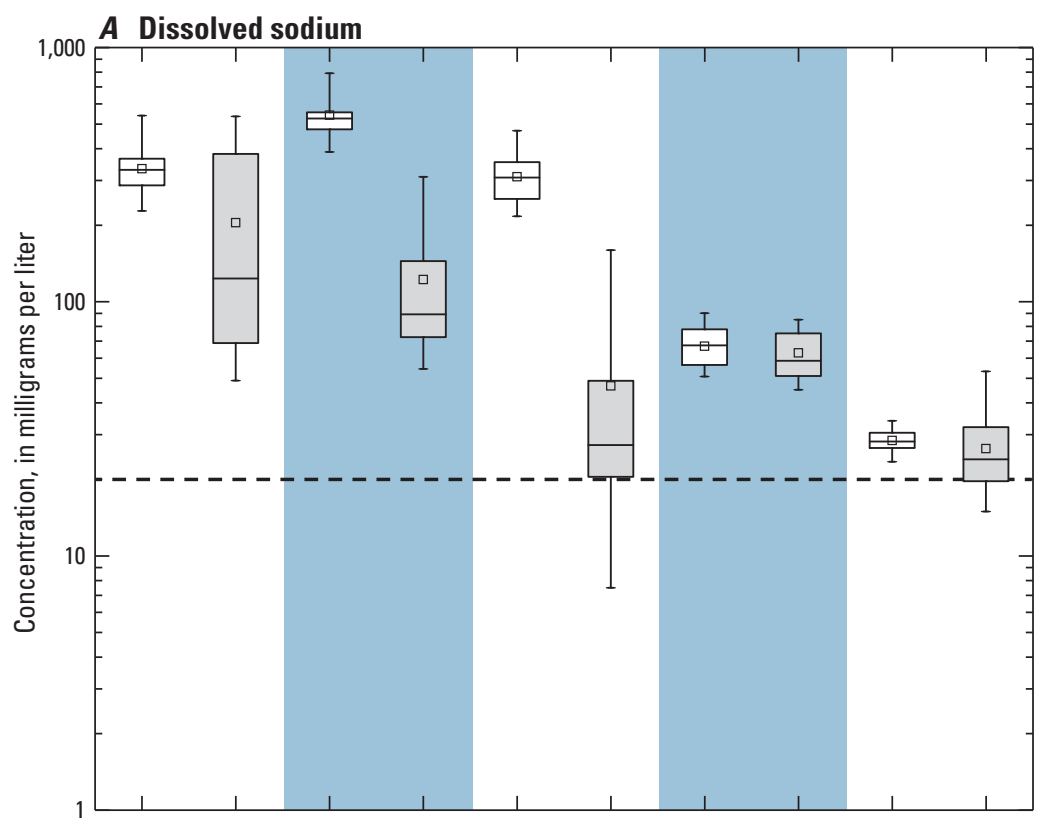

EXPLANATION
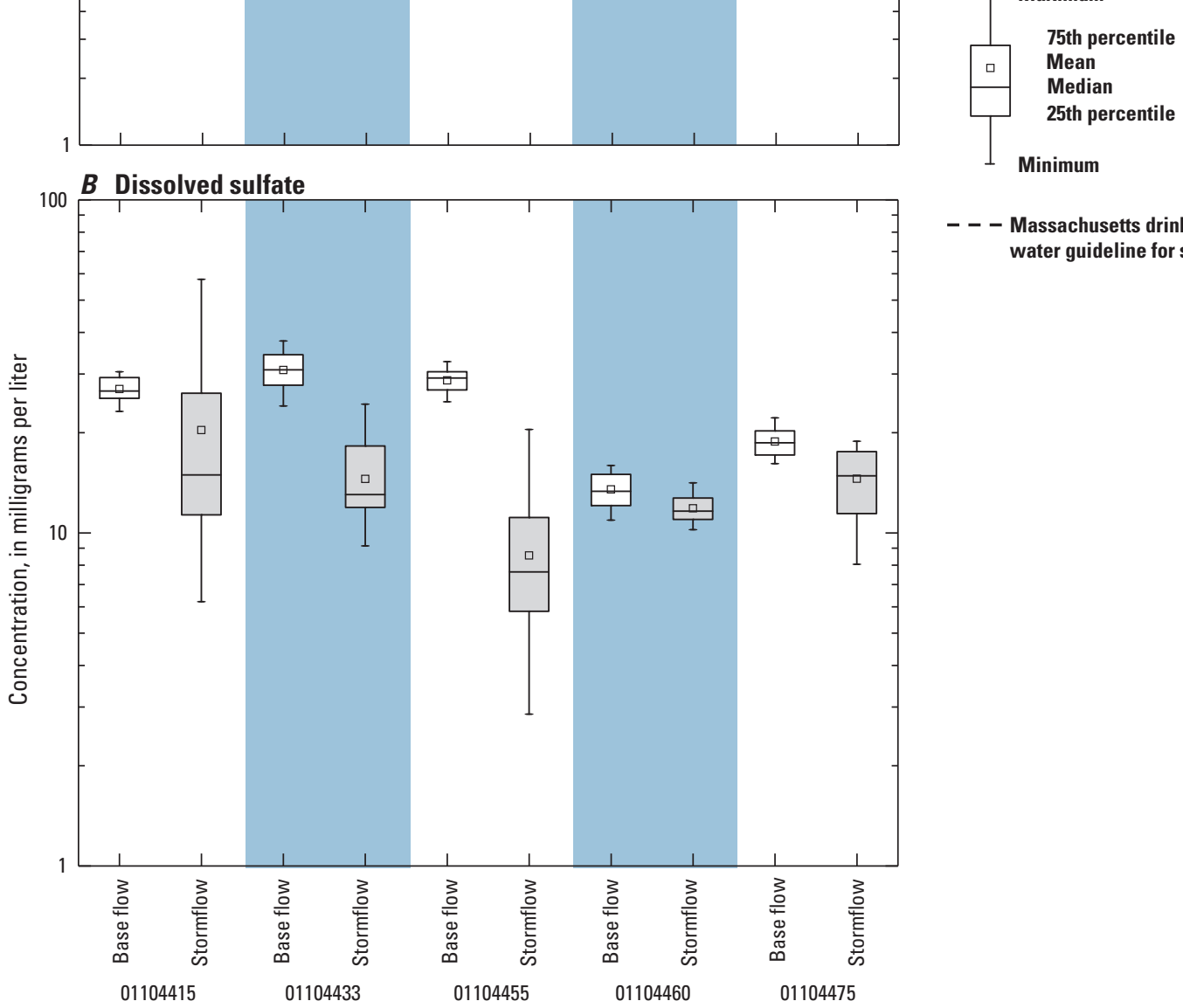

- Massachusetts drinking-
water guideline for sodium

Figure 12. Distributions of concentrations of $A$, dissolved sodium and $B$, dissolved sulfate in base-flow and stormflow samples from five U.S. Geological Survey stations in the Cambridge drinking-water source area, Massachusetts, water years 2005-07. [Data from the Commonwealth of Massachusetts, Executive Office of Energy and Environmental Affairs, Department of Environmental Protection, Water, Wastewater \& Wetlands: Regulations \& Standards, 2007, Massachusetts surface-water quality standards] 


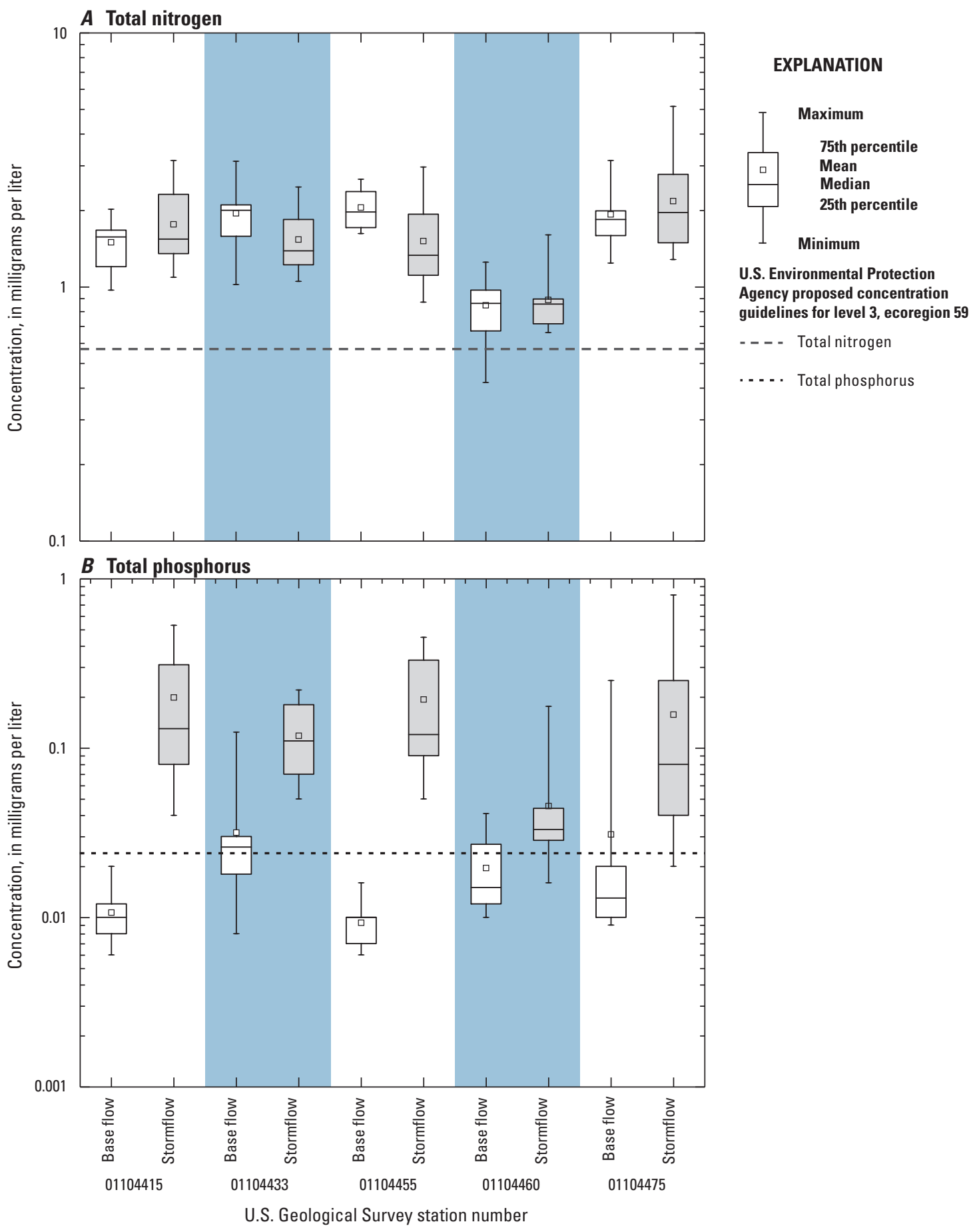

Figure 13. Distributions of concentrations of $A$, total nitrogen and $B$, total phosphorus in base-flow and stormflow samples from five U.S. Geological Survey stations in the Cambridge drinking-water source area, Massachusetts, water years 2005-07. [Data from U.S. Environmental Protection Agency, 2000] 


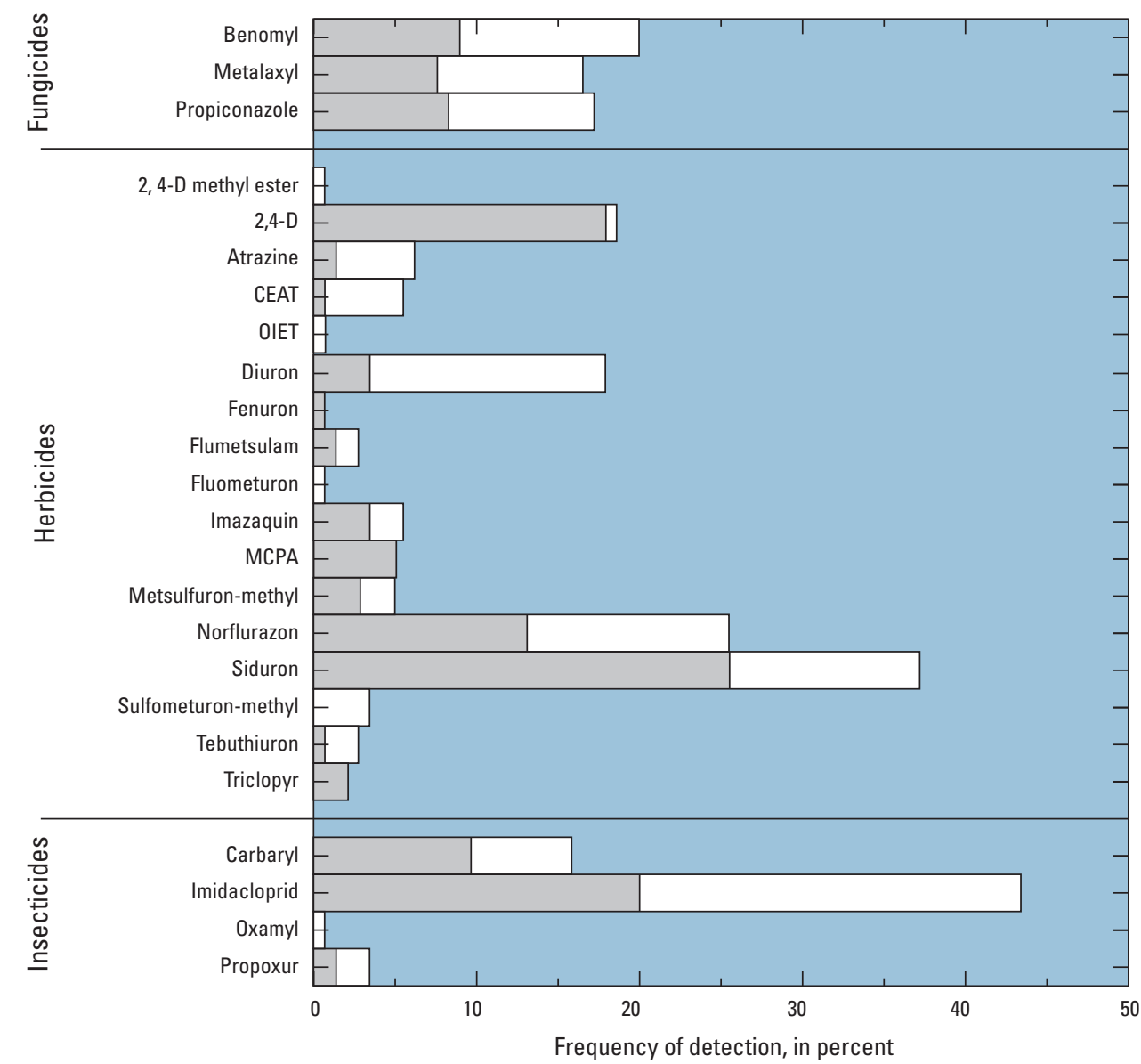

EXPLANATION

Overall detection frequency

Detection frequency in stormflow
Figure 14. Frequency of detection for selected pesticides in samples of base flow and stormflow collected at the primary sampling stations in the Cambridge drinking-water source area, Massachusetts, water years 2005-07. caffeine, and 12 pesticides (detected in samples of base flow or stormflow at a frequency greater than or equal to 25 percent) and land-use characteristics at four primary sampling stations (USGS stations 01104415, 01104433, 01104455, and 01104475; fig. 1) on tributaries in the Cambridge and Stony Brook Reservoir watersheds (table 2). The fifth primary sampling station, USGS station 01104460, was excluded because its watershed encompasses most of the drinking-water source area, including the Cambridge Reservoir, and it is likely that various transformations of the constituents could result during the immigration of water through the reservoir system that are not typical in the small subbasins. Annual flow-weighted concentrations were derived from load estimates for each subbasin. A second correlation analysis was performed for the available data on concentrations (mean concentrations of major ions and nutrients and maximum concentrations of selected pesticides) in base-flow samples collected from the primary and secondary USGS sampling stations (table 1). Maximum concentrations of selected pesticide concentrations were used instead of mean values because of the low frequency of detection for most compounds and the limited data available from the secondary sampling stations.

Correlations between annual flow-weighted concentrations of major ions and most land-use classes in the subbasins of the four primary sampling stations were not significant, although the strength of the relation between annual flowweighted concentrations of $\mathrm{Ca}, \mathrm{Cl}$, and $\mathrm{Na}$ and most roadways categories was moderately strong to strong, particularly for town roadways (table 11). The lack of statistical significance may be due, in part, to the small number of data values (four) available for the analysis. In contrast, correlations between mean concentrations of major ions in base flow and land-use classes in all 11 subbasins within the drinking-water source area were significant for most land uses associated with paved surfaces, except State roadways (table 12). Relations between mean concentrations of $\mathrm{Ca}$ in base flow and commercial and total impervious land uses (table 12 and fig. 15) were stronger than the relation between mean concentrations of $\mathrm{Ca}$ in base flow and total roadway land uses. Commercial landscape area and commercial roof area are unlikely sources of these constituents, but commercial areas are often proportional in 
size to the areas designated as commercial-industrial. As a result, these areas appear to relate to the concentration data. The moderately strong to strong relations between $\mathrm{Ca}$ and various commercial areas is potentially the result of winter applications of calcium chloride, as opposed to applications of sodium chloride that are restricted by the local conservation commissions (David Kaplan, city of Cambridge Water Department, written commun., 2011) for sidewalks and parking areas in the commercial areas. Liquid calcium chloride also is used under specific conditions on the State maintained roads in the drinking-water source area (Commonwealth of Massachusetts, Massachusetts Highway Department, 2008). The relation between concentrations of deicing constituents and roadway area in the drinking-water supply area is consistent with findings from a prior study by the USGS (Waldron and Bent, 2001).

Positive correlations between annual flow-weighted concentrations of TN in samples collected at the four primary sampling stations and percentages of recreational area and open-water area are significant (table 11); strong negative correlations between annual flow-weighted concentrations of $\mathrm{TN}$ and many of the classes of roadway areas also are significant. Positive correlations between mean concentrations of $\mathrm{TN}$ in base flow and commercial landscape, Interstate road, State maintained road, and total impervious area are significant (table 12). Correlations between annual flow-weighted concentrations of TP and percentages of forest and State roadway indicate that the relations are moderately strong; however, the relations are significant only at lower confidence intervals (about 87 percent). No significant relations between mean concentrations of TP in base flow and percentage of land-use class were found (table 12), except for commercial roof land use. A strong negative correlation between annual flow-weighted concentrations of TP and wetland land use was found; however, correlations are neither strong nor significant for mean concentrations of TP in base flow and wetland land use, likely because the concentrations were consistently low among subbasins during base-flow conditions.

Annual flow-weighted concentrations of the pesticides benomyl, imidacloprid, and carbaryl in samples collected at the four primary sampling stations correlated significantly with the percentages of recreational and open-water land uses (table 11). Mean concentrations of these pesticides in base flow also correlated significantly with recreational land use throughout the drinking-water supply area (table 12). Although the correlations between recreational land use and annual flow-weighted concentrations of benomyl and carbaryl were significant in both of the previous analyses, these pesticides were detected only in samples collected at two and three primary sampling stations, respectively. The annual flow-weighted concentration of the herbicide 2, 4-D, a commonly used weed killer (table 9), correlated significantly with residential-roof land use for the four primary sampling stations. Lot sizes in the drinking-water source area are relatively large (greater than a hectare in some towns), and lots often contain landscaped areas and (or) lawns that tend to be separated from neighboring houses by woodlots. Thus, residential-roof land use is not likely a source of the herbicide but more likely represents the mean size of a lawn or landscaped area of homes in the watershed. A significantly strong correlation between the insecticide diuron and parking lot land use was found. Relations between maximum concentrations of diuron in base flow and most land-use classes are weak (table 12), except for commercial and parking lot land uses, which are moderately strong. Annual flow-weighted concentrations of the herbicide siduron for the four primary sampling stations correlated significantly with wetland land use (table 11). Moderately strong relations between the herbicide and commercial roof area and parking lots were significant only at lower confidence levels $(\alpha=0.88)$. Maximum concentrations of siduron in base flow correlated significantly with various commercial land-uses, as well as, total impervious area throughout the drinking-water supply area (table 12). Commercial rooftop and parking lot land uses can represent a substantial amount of the total impervious area in many of the subbasins. Although it is unlikely that commercial rooftops and parking lots are sources of siduron, the area of these land-use classes may be correlated with commercial landscape areas. Siduron is a component of lawn-starter fertilizers. It is relatively persistent compared to many herbicides, and on the basis of its physical characteristics (table 9), the compound is likely to immigrate to groundwater or mobilize in overland stormflows.

Except for town road land use, and to a lesser extent total roadway, most correlation test results for annual flowweighted concentrations of caffeine in samples collected at the four primary sampling stations and land-use classes are weak (table 11). The moderately strong relation between town road land use and annual flow-weighted concentrations of caffeine (table 12 and fig. 15) were significant only at a lower confidence interval $(\alpha=0.87)$. Maximum concentrations of caffeine in base flow correlated significantly with parking lot and commercial roof land uses throughout the watersheds; however, the relation was only moderately strong (table 12). Most areas in the watersheds are connected to integrated sewage systems, thus low-level concentrations of caffeine are potentially related to leaking sewer lines, as well as, litter or spilled beverages, which often are found on or near roadways and parking lots. In general, correlations of water-quality data and land use were limited by the small data set, particularly where concentration data are below detection limits and where landuse classes are not consistently present among the subbasins.

\section{Comparison of Water-Quality Properties and Constituent Concentrations with Water-Quality Criteria and Guidelines}

Values of water-quality properties and concentrations of constituents in samples from watersheds are compared to various criteria and guidelines. The Commonwealth of Massachusetts, Executive Office of Energy and Environmental Affairs, Department of Environmental Protection, Water, Wastewater 

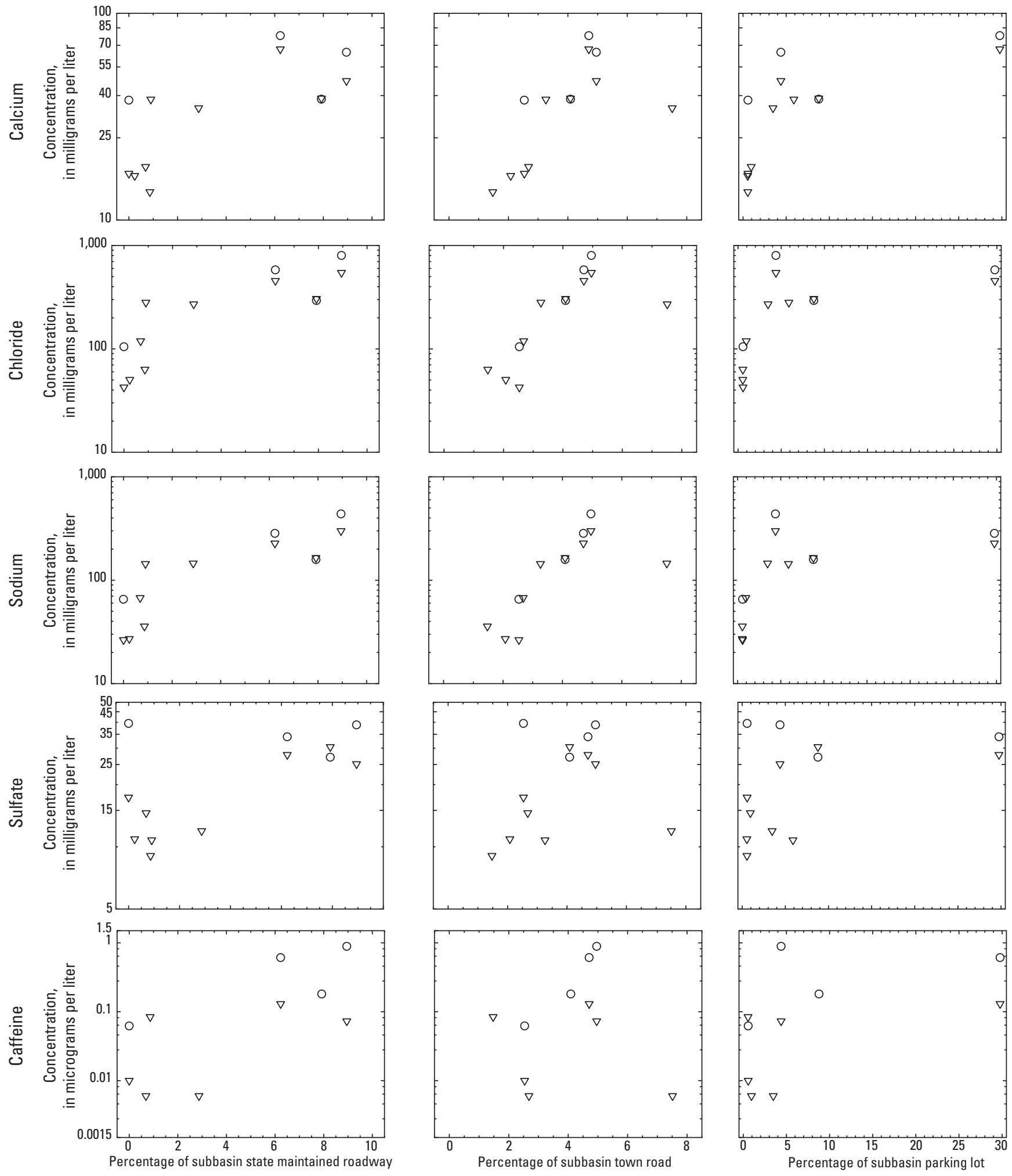

EXPLANATION

O Mean annual flow-weighted concentration of ions and caffeine at primary sampling station

$\nabla$ Mean concentration of ions in base flow or maximum concentration of caffeine in base flow at primary and secondary sampling station

Figure 15. Concentrations of calcium, chloride, sodium, sulfate, and caffeine in relation to the areal percentage of State maintained roads, town roads, and parking lots in 11 subbasins in the Cambridge drinking-water source area, Massachusetts, water years 2005-07. 


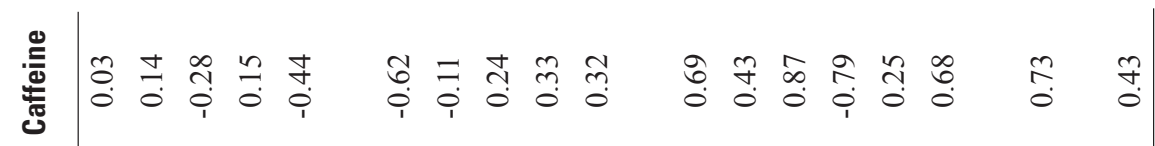

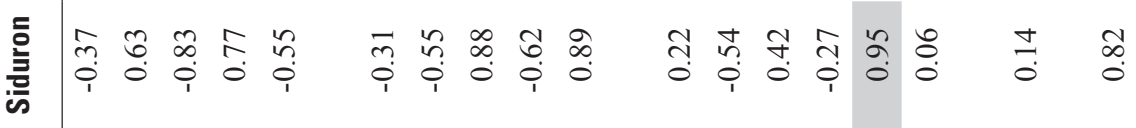

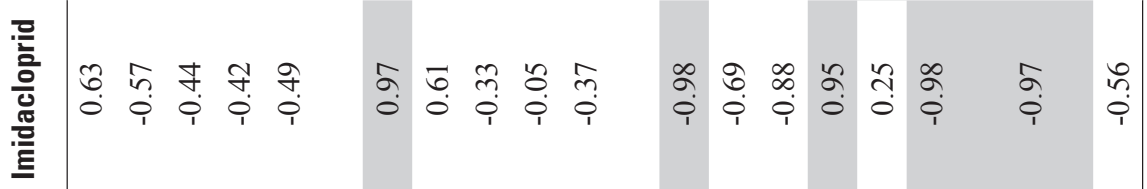

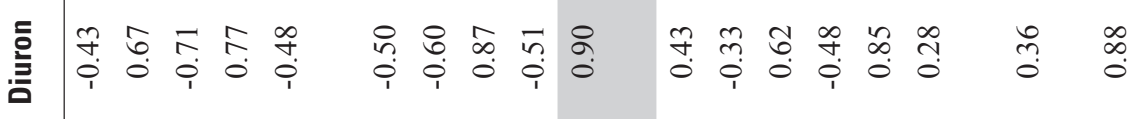

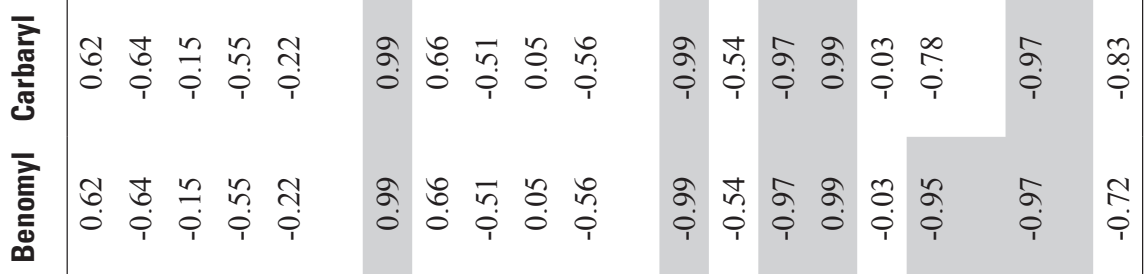

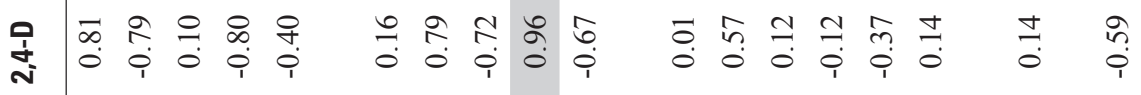

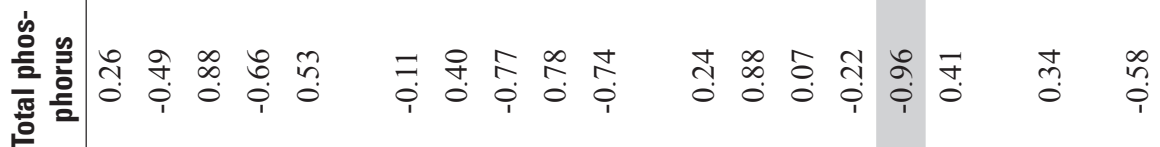

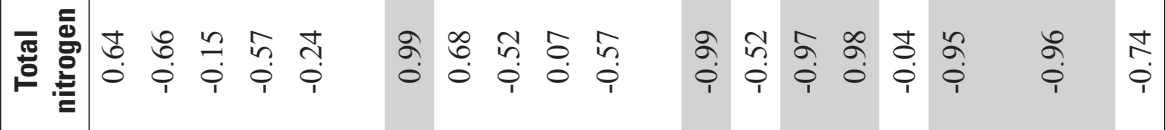

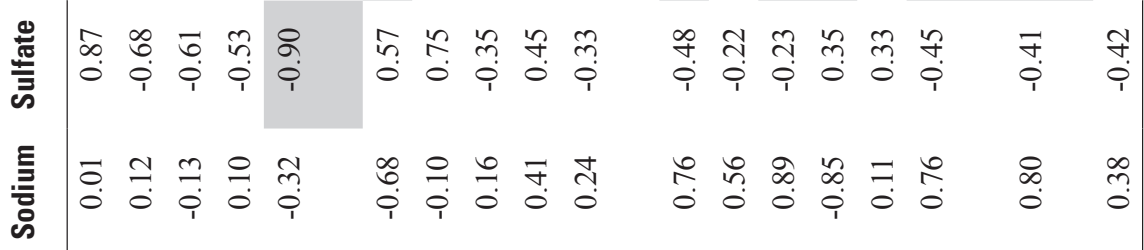

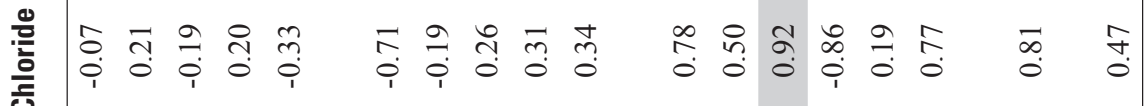

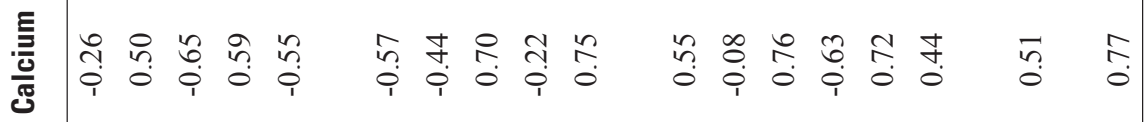

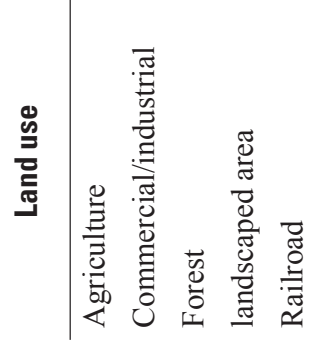

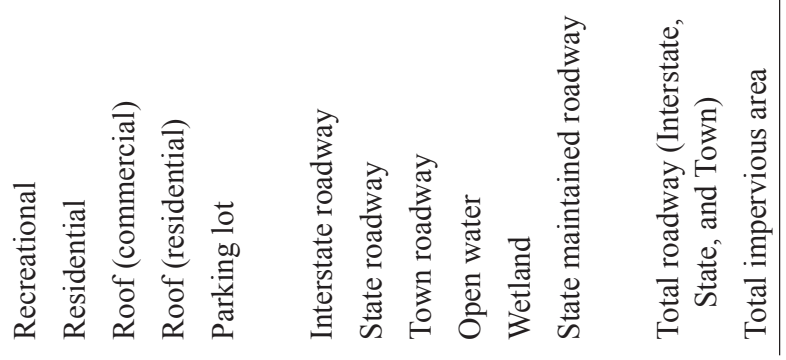




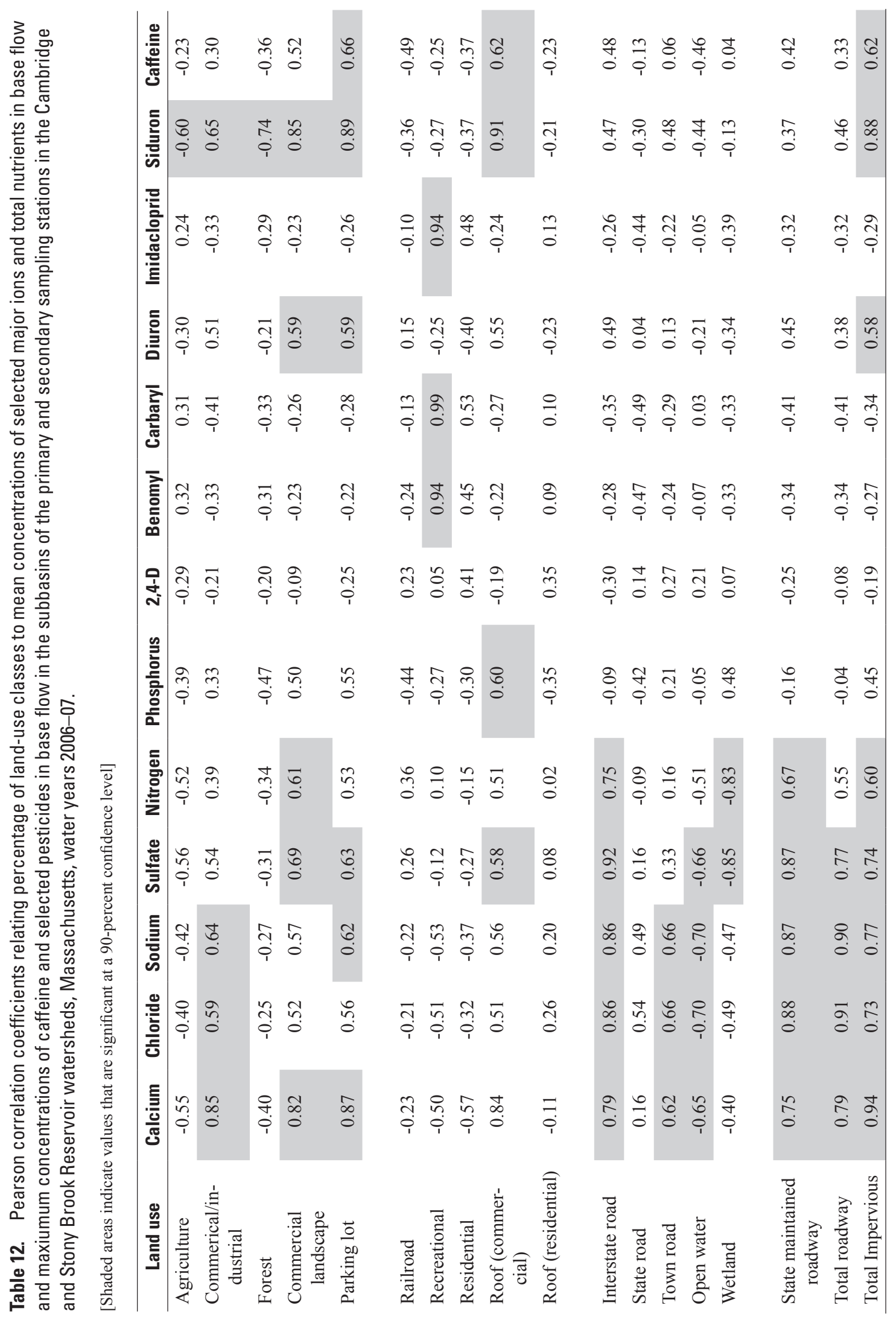


\& Wetlands: Regulations \& Standards (MassEOEEA) sets water-quality standards for surface water on the basis of the intended use. Waters designated as Class A specifically include sources of public water supplies and their tributaries. Standards for Class A waters applicable to the data presented in this report pertain to $\mathrm{pH}$, dissolved oxygen, and $\mathrm{Na}$ in drinking water (MassEOEEA, 2009). The U.S. Environmental Protection Agency (USEPA) has established various water-quality guidelines, including the criterion continuous concentration (CCC), also referred to as a chronic concentration, and the criterion maximum concentration (CMC) for freshwater aquatic life, secondary drinking-water regulations (SDWRs), maximum contaminant levels (MCLs), and drinking-water lifetime exposure levels (DWELs) for finished drinking water. The USEPA CCC is an estimate of the highest concentration of a constituent to which an aquatic community can be exposed indefinitely without adverse effects. In contrast, the USEPA CMC is an estimate of the highest concentration of a constituent to which an aquatic community can be exposed briefly without adverse effects. SDWRs are non-mandatory water-quality guidelines established by the USEPA and are designed to assist public water suppliers in managing aesthetic aspects of water, such as taste, odor, color, foaming, corrosivity, staining, scaling, and sedimentation; the regulations are not related to risk to human health (U.S. Environmental Protection Agency, 2007). Although these guidelines typically are applied to finished water, the presence of these constituents at concentrations exceeding SDWRs can result in damage to equipment and reduce the effectiveness of treatment for other constituents. Some constituents, such as $\mathrm{Cl}, \mathrm{Na}$, and $\mathrm{N}$, are not effectively removed by the Cambridge water-treatment facility (Smith, 2007). MCLs and DWELs were established to protect human health. USEPA SDWRs and guidelines for drinking water are useful benchmarks used for comparison with constituent concentrations in the drinking-water source area. Turbidity and nutrient data are compared to USEPA reference values, which are considered representative of pristine or minimally affected waters (U.S. Environmental Protection Agency, 2000). Finally, pesticide concentrations are compared to Canadian long-term aquatic life guidelines established to protect the most sensitive organism during its most sensitive life stage from any adverse effects associated with long-term exposure (Canadian Council of Ministers of the Environment, 2011).

Measurements of $\mathrm{pH}$, specific conductance, and dissolved oxygen concentration in samples collected in the drinkingwater source area seldom exceeded available water-quality criteria. In about 8 percent of water samples, primarily baseflow samples, $\mathrm{pH}$ was less than the MassEOEEA minimum standard of $6.5 \mathrm{pH}$ units (tables 7 and 8). Dissolved oxygen concentrations, which were measured only during base-flow conditions, were less than the MassEOEEA guideline of 5 $\mathrm{mg} / \mathrm{L}$ for warm-water fisheries in about 7 percent of the water samples collected at USGS stations 01104420, 01104433, and 01104453 . The low dissolved oxygen concentrations occurred during periods of low streamflow. Turbidity in about
76 percent of water samples exceeded the USEPA proposed reference value of 1.68 nephelometric turbidity units (NTUs, which is similar to NTRUs for data reported in this study) for level 3, ecoregion 59 (U.S. Environmental Protection Agency, 2000, table 4a), which covers most of eastern Massachusetts, except for Cape Cod. Turbidity of all composite stormflow samples exceeded this reference value. The turbidity of only 1 of 15 base-flow samples collected at USGS station 011104455 exceeded the reference value. The low turbidity of samples from this site is likely the result of the containment of much of the upstream tributary in a subsurface pipe where the water is not exposed to sunlight, thereby, greatly limiting algal growth. The $\mathrm{pH}$ and turbidity of samples collected from the raw-water intake at Fresh Pond Reservoir did not exceed the aforementioned criteria.

Concentrations of dissolved $\mathrm{Cl}$ and $\mathrm{Na}$ in water samples commonly exceeded the USEPA SDWR for $\mathrm{Cl}$ ( 250 $\mathrm{mg} / \mathrm{L}$ ) and the MassEOEEA drinking-water guideline for $\mathrm{Na}(20 \mathrm{mg} / \mathrm{L})$. About 38 and 35 percent of concentrations of $\mathrm{Cl}$ in water samples collected in the drinking-water source area during 2004-07 exceeded the USEPA CCC and SDWR standards, respectively. During this study, $\mathrm{Cl}$ guidelines were not exceeded in water samples from USGS stations 01104390 , 01104453, 01104460 and 01104475, which are on tributaries to the Stony Brook Reservoir that drain less developed parts of the drinking-water source area. Concentrations of $\mathrm{Cl}$ in samples collected from the raw-water intake at Fresh Pond Reservoir did not exceed the guidelines (tables 7 and 8). The concentrations of $\mathrm{Cl}$ in stormflow samples exceeded guidelines less frequently than in base-flow samples. However, the highest concentration of $\mathrm{Cl}(1,050 \mathrm{mg} / \mathrm{L})$ measured in any sample of streamwater during the study period, which exceeded the USEPA CMC, was measured in a composite stormflow sample from USGS station 01104415 on a tributary along Interstate 95 north of the Cambridge Reservoir.

As discussed previously, concentrations of many major ions tend to decrease with increasing flows. This also tends to be the case during winter storms despite high concentrations of deicing compounds in runoff at the onset of the storm. Data on $\mathrm{Cl}$ concentrations, as well as concentrations of other constituents discussed in this report, are limited by the number of samples collected in the tributaries of the drinking-water source area. However, continuous records of specific conductance are available for nearly the entire study period. These records of specific conductance indicate that the USEPA CCC and SDWR for $\mathrm{Cl}$, estimated at a given level of specific conductance, were frequently exceeded during base-flow conditions at USGS stations 01104415, 01104433, and 01104455; the subbasins represented by these stations contain large paved areas (table 2; figs. 16-18). These data also indicate that flow-weighted values of specific conductance during runoff events exceed the specific conductance levels estimated at the concentrations for the USEPA SDWR and CCC thresholds for $\mathrm{Cl}$ less frequently than during base flow; however, some fraction of specific conductance during some runoff events is substantially greater than the maximum specific conductance 
during base flow. Specific conductance values rarely exceeded the levels estimated at the concentrations for the SDWR and CCC thresholds for $\mathrm{Cl}$ at USGS station 01104475 in a lowdensity residential area west of the Stony Brook Reservoir (fig 19). About 6 percent of the daily mean values of specific conductance in water released from the Cambridge Reservoir exceeded the levels estimated at the concentrations for the SDWR and CCC thresholds for Cl; the estimated CMC threshold for $\mathrm{Cl}$ was not exceeded during water years 2004-08. Measurements of specific conductance in Stony Brook (USGS station 01104460), which receives a mixture of water from the Cambridge Reservoir and from the less developed areas of the upper Stony Brook Reservoir watershed, were rarely (less than 0.5 percent) greater than the specific conductance levels estimated at the concentrations for the SDWR and CCC thresholds for $\mathrm{Cl}$.

Concentrations of dissolved $\mathrm{Na}$ in water samples collected throughout the drinking-water supply area, as well as from the raw-water intake at the Fresh Pond Reservoir, routinely exceeded the Massachusetts drinking-water guideline $(20 \mathrm{mg} / \mathrm{L})$. Only in a few composite stormflow samples was the concentration of $\mathrm{Na}$ less than the guideline (table 7). Concentrations of $\mathrm{Na}$ estimated from records of specific conductance also tended to be greater than the guideline.

Concentrations of TN and TP collected in samples from the drinking-water source area generally exceeded the proposed reference concentrations of 0.57 and $0.024 \mathrm{mg} / \mathrm{L}$, respectively, for level 3, ecoregion 59 (U.S. Environmental Protection Agency, 2000). These reference values represent the 25 th percentile of all nutrient data for the ecoregion 59 and are intended to protect streams and rivers from the adverse effects of nutrient enrichment (U.S. Environmental Protection Agency, 2000). Concentrations of TN exceeded this reference concentration in 94 percent of all water samples and 100 percent of all samples collected from the raw-water intake at the Fresh Pond Reservoir. Concentrations of TP exceeded this reference concentration in 56 percent of all water samples. With few exceptions, concentrations of TP in all composite stormflow samples exceeded the reference value of $0.024 \mathrm{mg} / \mathrm{L}$. Generally, concentrations of TP in samples collected during base-flow conditions were near or below the reference concentration.

Pesticides measured in this study were detected in less than one-half of the water samples collected in the watersheds during water years 2004-08. Although the frequency of detection varied from tributary to tributary, concentrations of pesticides typically were less than $1 \mu \mathrm{g} / \mathrm{L}$ and much less than drinking-water guidelines. Pesticide concentrations also were several orders of magnitude less than the LC50s for several fish species common to the watershed. The LC50 is a standard measurement of toxicity for exposure to an analyte

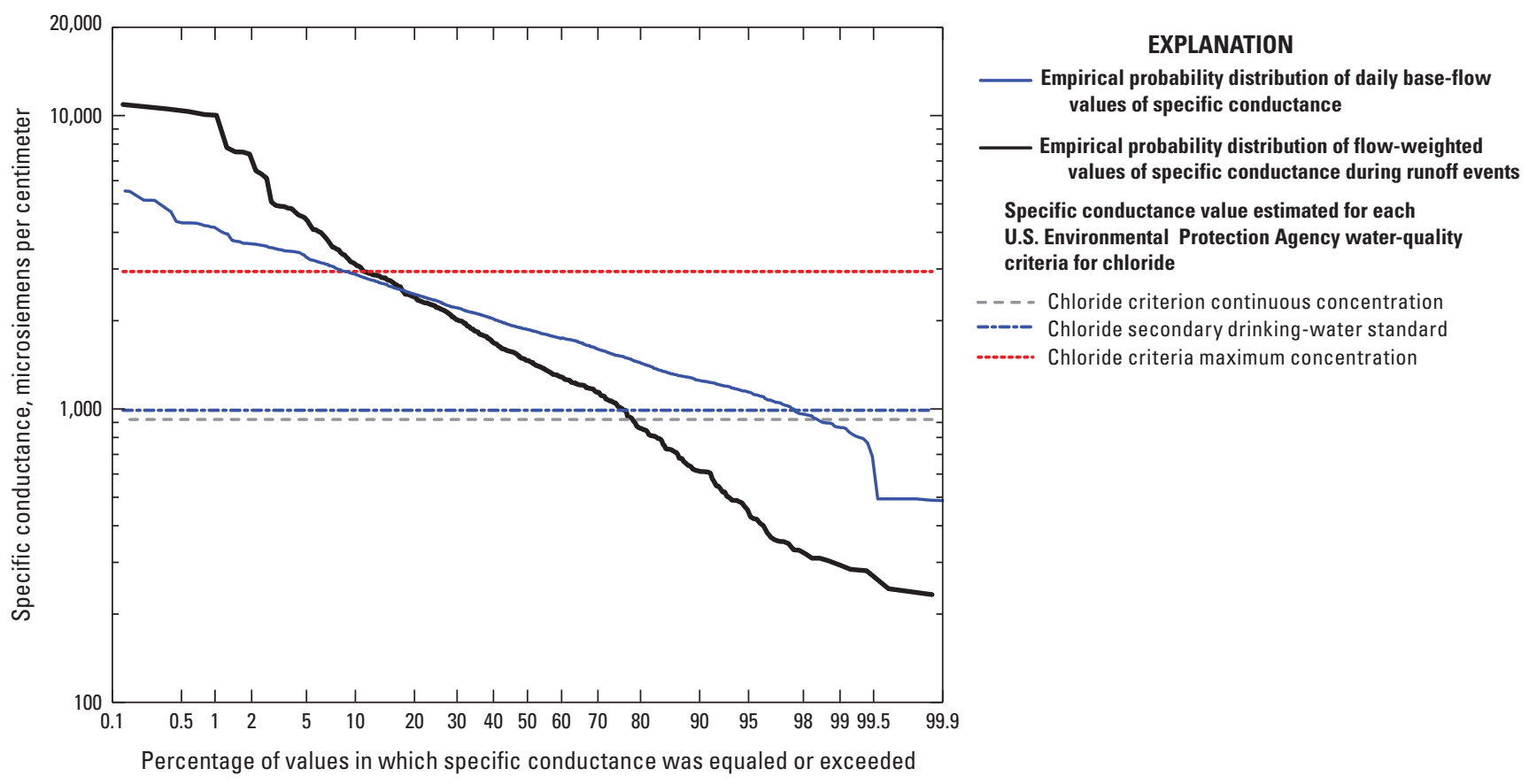

Figure 16. Probability distribution of daily specific conductance values during base flow and flow-weighted specific conductance values during runoff for U.S. Geological Survey station 01104415, Cambridge drinking-water source area, Massachusetts, in relation to estimated concentration values representing U.S. Environmental Protection Agency water-quality criteria for chloride, water years 2004-08. 


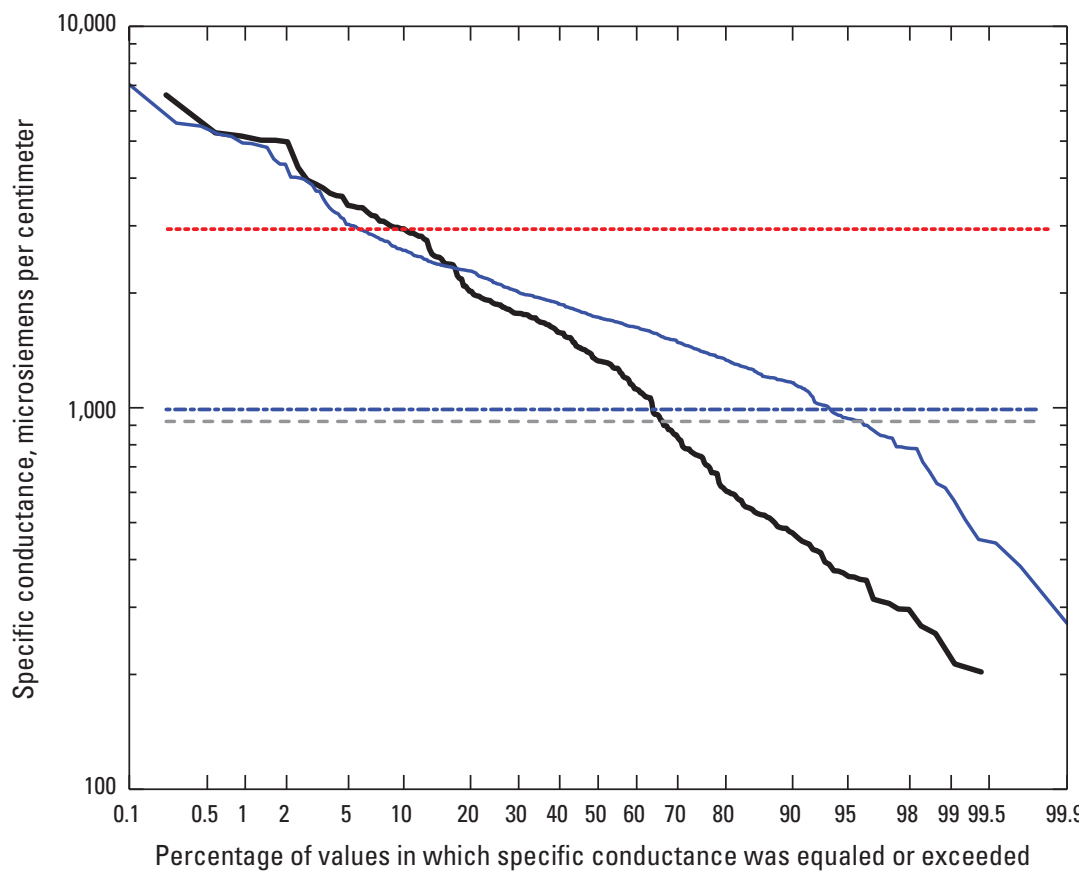

EXPLANATION

Empirical probability distribution of daily base-flow values of specific conductance

Empirical probability distribution of flow-weighted values of specific conductance during runoff events

Specific conductance value estimated for each

U.S. Environmental Protection Agency water-quality criteria for chloride

- - - Chloride criterion continuous concentration

---- Chloride secondary drinking-water standard

....... Chloride criteria maximum concentration

Figure 17. Probability distribution of daily specific conductance values during base flow and flow-weighted specific conductance values during runoff for U.S. Geological Survey station 01104433, Cambridge drinking-water source area, Massachusetts, in relation to estimated concentration values representing U.S. Environmental Protection Agency water-quality criteria for chloride, water years 2004-07.

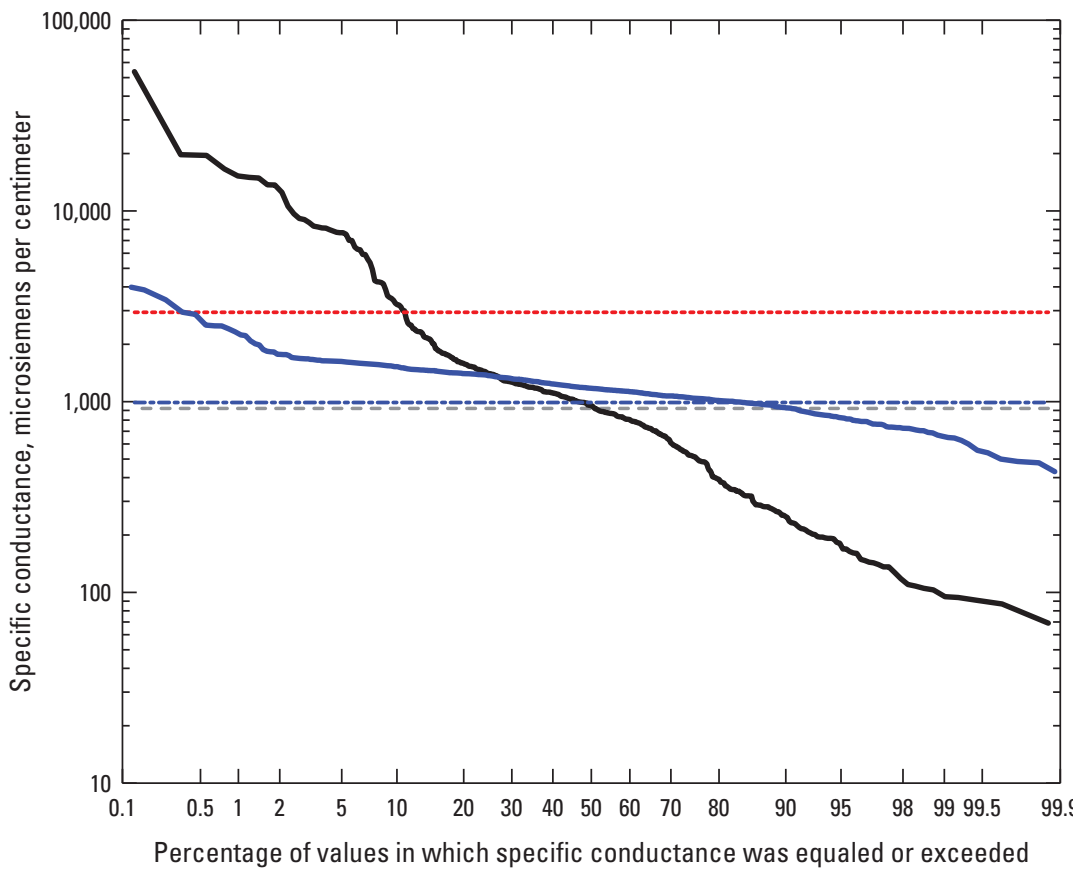

\section{EXPLANATION}

Empirical probability distribution of daily base-flow values of specific conductance

Empirical probability distribution of flow-weighted values of specific conductance during runoff events

Specific conductance value estimated for each

U.S. Environmental Protection Agency water-quality criteria for chloride

- - - Chloride criterion continuous concentration

-.- Chloride secondary drinking-water standard

-...... Chloride criteria maximum concentration

Figure 18. Probability distribution of daily specific conductance values during base flow and flow-weighted specific conductance values during runoff for U.S. Geological Survey station 01104455, Cambridge drinking-water source area, Massachusetts, in relation to estimated concentration values representing U.S. Environmental Protection Agency water-quality criteria for chloride, water years 2004-08. 


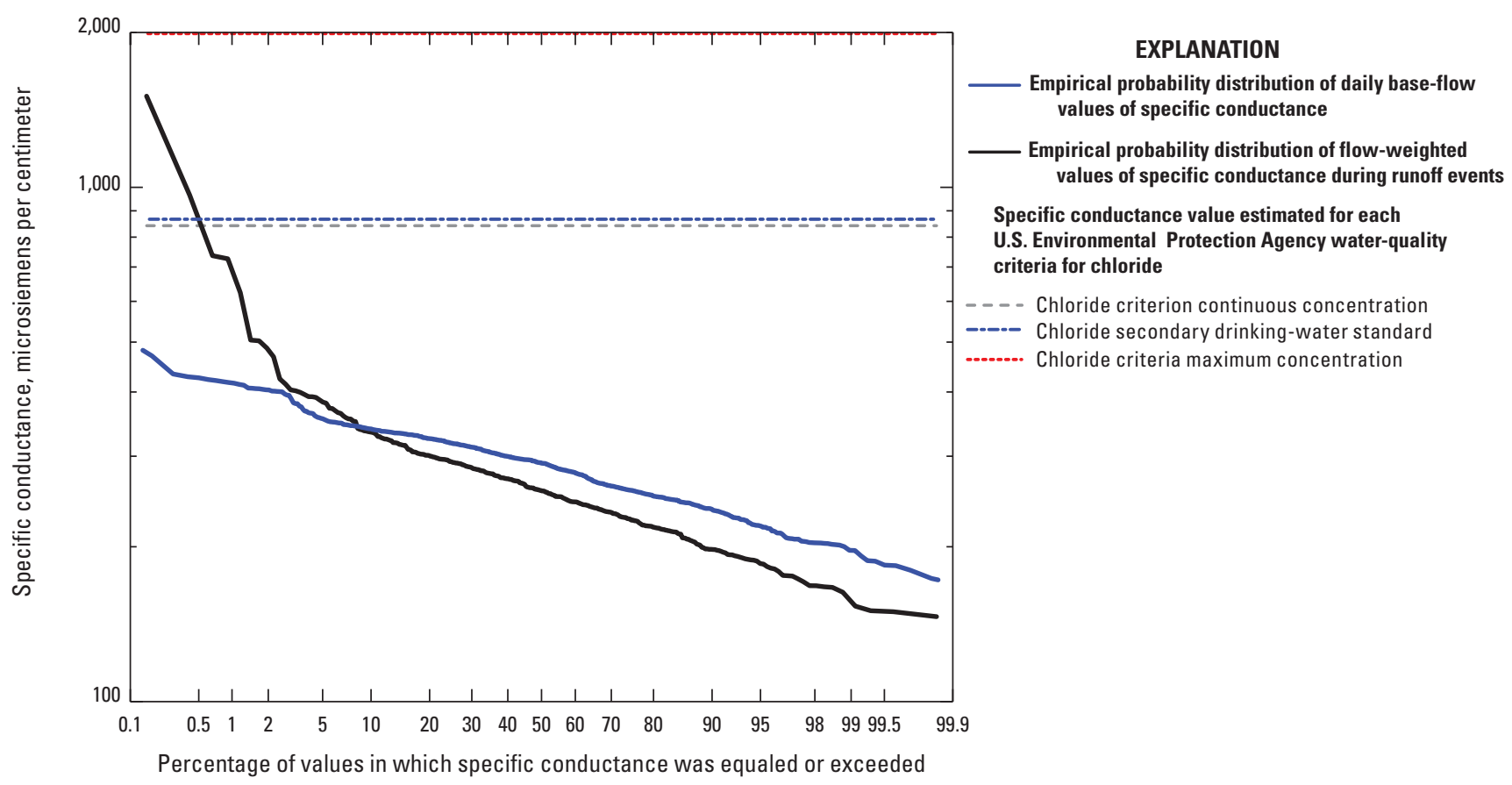

Figure 19. Probability distribution of daily specific conductance values during base flow and flow-weighted specific conductance values during runoff for U.S. Geological Survey station 01104475, Cambridge drinking-water source area, Massachusetts, in relation to estimated concentration values representing U.S. Environmental Protection Agency water-quality criteria for chloride, water years 2004-08.

concentration that is lethal for half of the sample population over a specified period.

Imidacloprid is the only pesticide detected at a concentration that exceeded the Canadian long-term aquatic-life guidelines (table 10). Although imidacloprid (an insecticide) was detected in samples from many of the sampling stations (table 7 and 8), the frequency of detection varied by station. The frequency of detection of imidacloprid in samples from sampling station 01104475, which drains a residential area adjacent to the Stony Brook Reservoir, was 94 percent with 42 percent of the samples exceeding the Canadian long-term aquatic-life guideline of $0.23 \mu \mathrm{g} / \mathrm{L}$.

\section{Constituent Loads and Yields}

Load and yield estimates for the study stations provide information about the rates at which masses of constituents are transported to the reservoir. Tributaries with higher flows tend to have higher loads because the greater volume of water can carry more of the constituent (assuming similar constituent concentrations in each tributary) to the reservoir per unit time. Yields represent the constituent load per unit of drainage area and are calculated by dividing the estimated load for a station by the drainage area for the station. Yields are useful for comparison of different drainage-area sizes because the effects of basin size and, therefore, total streamflow volume are normalized with respect to basin area. Yields are useful for examining potential differences among basin properties that may affect water quality.

Loads for each constituent were estimated on the basis of the measure of the central tendency (table 13) and annual volumes of base flow and total flow during storms. For many constituents, the mean concentration of the sample set was expected to be similar to the population mean. However, for sample concentrations that appeared to follow a log-normal distribution, the population means were estimated with the assumption that the logarithms of the data were symmetric. This approach provides a better estimate of the population mean (Helsel and Hirsch, 2002). Loads for were not estimated for caffeine and pesticides at sites where these analytes were infrequently detected because data were insufficient to estimate mean concentrations.

\section{Loads and Yields of Calcium, Chloride, Sodium, and Sulfate, Water Years 1999 to 2008}

Loads and yields of $\mathrm{Ca}, \mathrm{Cl}, \mathrm{Na}$, and $\mathrm{SO}_{4}$ were estimated for the five primary sampling stations for water years 2005-07 on the basis of streamflow and concentration data collected during this study (table 14). Loads and yields for these constituents also were estimated for all monitoring stations for 


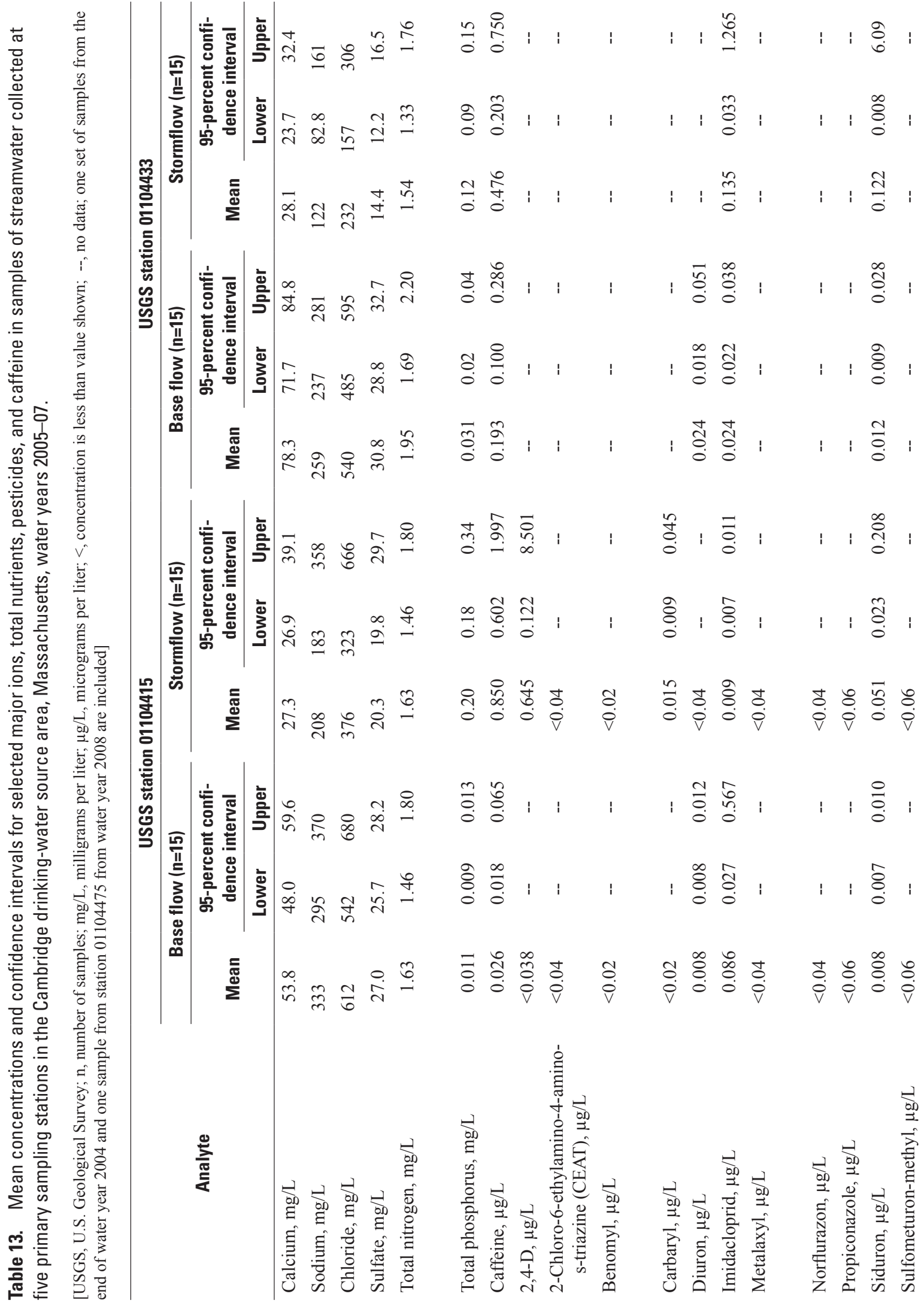




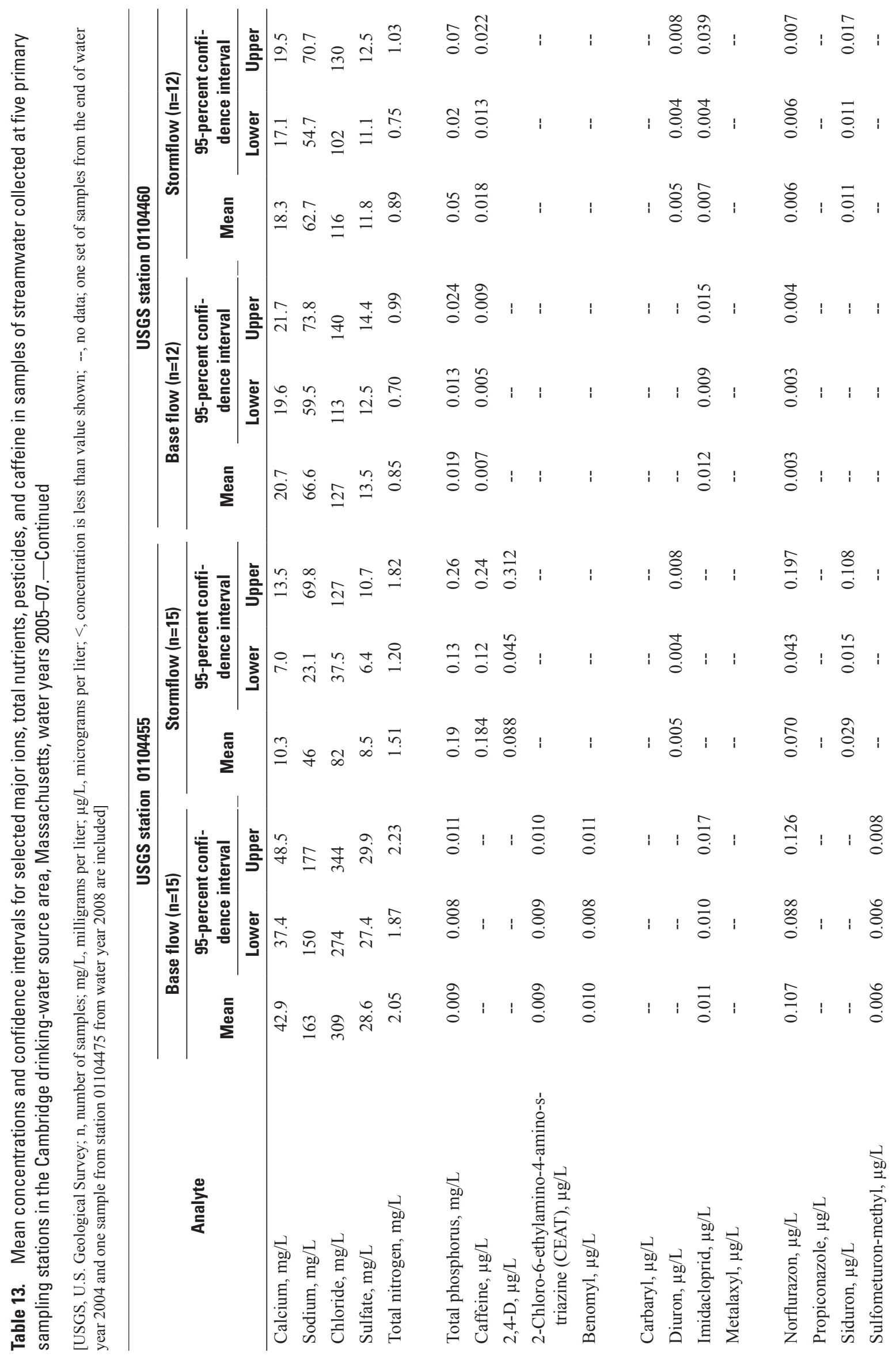




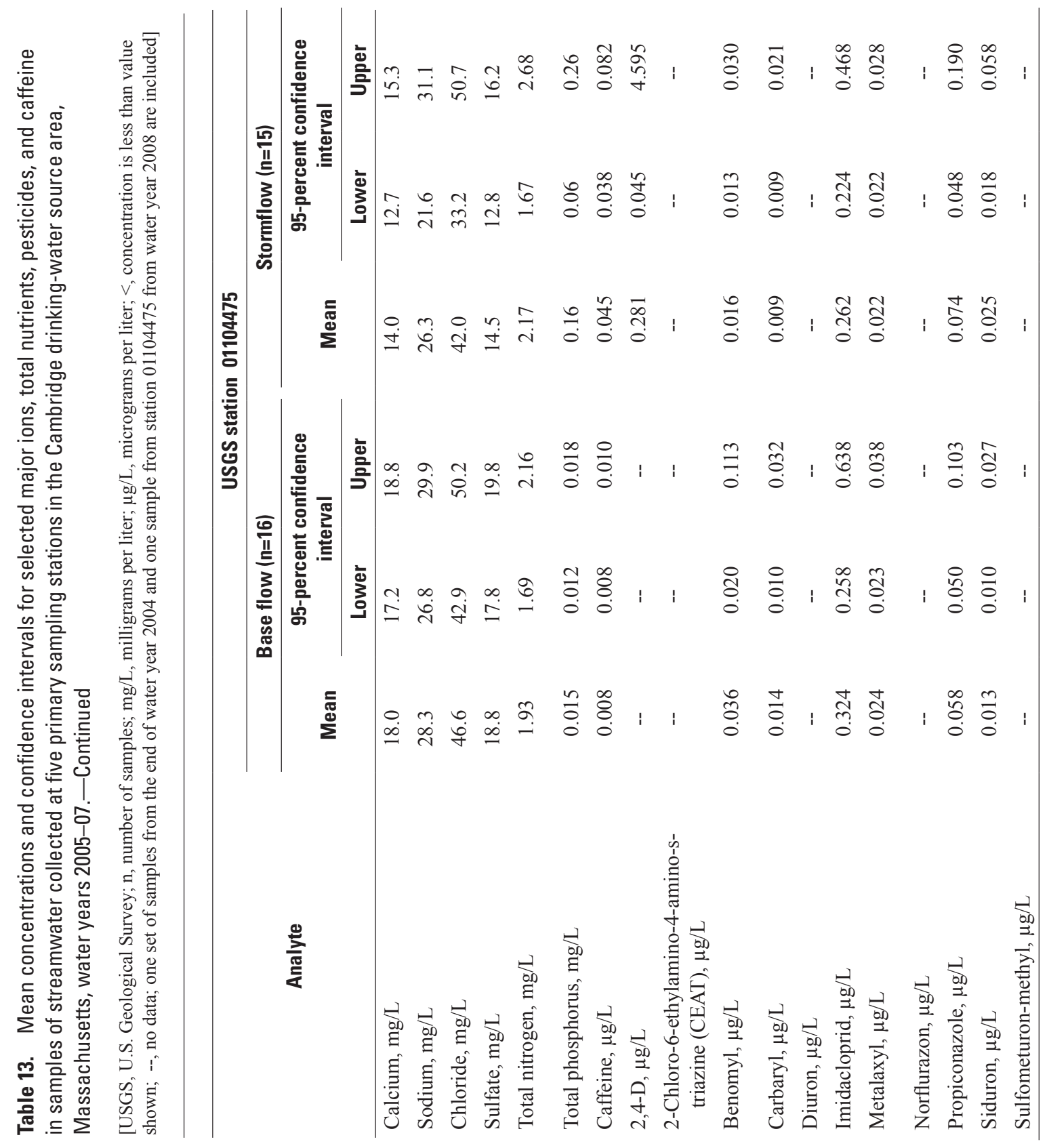


which streamflow and continuous specific-conductance data were available since water year 1999 (table 15). Loads were estimated on the basis of the correlations between concentration data for $\mathrm{Ca}, \mathrm{Cl}, \mathrm{Na}$, and $\mathrm{SO}_{4}$ and values of specific conductance.

Loads and yields for major ions calculated from continuous records of specific conductance were similar to those calculated on the basis of mean concentration data (tables 14 and 15). Except for loads of $\mathrm{Cl}$ and $\mathrm{Na}$ at USGS station 01104455 , the 95-percent confidence intervals of loads estimated using both of these methods overlapped. Loads and yields for $\mathrm{Cl}$ and $\mathrm{Na}$ estimated from concentration data for USGS station 01104455, where the 95-percent confidence intervals of load estimates did not overlap, are lower than those estimated from continuous records of specific conductance. These differences indicate that the samples collected at this station do not accurately represent mean water-quality conditions at these stations. This is likely the result of an insufficient number of winter runoff samples since base-flow concentration data were relatively precise throughout the year. Loads and yields estimated on the basis of continuous records of specific conductance are expected to be more accurate than those estimated from sample concentration data because the continuous record estimated loads and yields represent a broader range of hydrologic conditions, including information from all runoff events, including snow melts.

Annual loads of $\mathrm{Ca}, \mathrm{Cl}, \mathrm{Na}$, and $\mathrm{SO}_{4}$ estimated on the basis of streamflow and mean concentration data varied from year to year and station to station and, as a result, were correlated with annual streamflow (table 15). Mean annual yields of $\mathrm{Ca}, \mathrm{Cl}, \mathrm{Na}$, and $\mathrm{SO}_{4}$ for the drinking-water source area (data from USGS stations 01104460 and 01104475 ) for water years 2005 to 2007, estimated on the basis of continuous records of specific conductance, were $14,85,46$, and 9 metric tons per square kilometer $\left(\mathrm{MT} / \mathrm{km}^{2}\right)$, respectively. The tributary adjacent to Interstate 95 in the Cambridge Reservoir watershed (USGS station 01104415) had the highest yields for all major ions. Mean annual yields of major ions at this station (table 15) were 4.3 to 8.3 times higher than the mean annual yields for the drinking-water source area. Mean annual yields of most major ions at USGS stations 01104433 and 01104455 , in subbasins that also contain large areas of roadways and parking lots (table 2), were substantially higher than mean annual yields for the drinking-water source area. Yields of major ions for USGS station 01104475, which drains the subbasin with the highest percentage of residential land use and one of the lowest percentages of roadways, were the lowest in the drinking-water source area, and only 13 percent of the yield came from stormflow. In contrast, about 30 percent of the yields (estimated from records of flow and specific conductance) of each major ion for the other stations was associated with stormflow (table 15). The stormflow component of total loads estimated from sample concentration data (table 14) tends to be larger than that estimated from specific conductance data because the base-flow component is included in the stormflow volume.
Annual mean yields of $\mathrm{Cl}$ and $\mathrm{Na}$ estimated for water year 1999 at USGS station 01104415 (Waldron and Bent, 2001) were similar to the respective annual mean yields estimated for water years 2005 to 2007 . However, annual mean yields of $\mathrm{Cl}$ and $\mathrm{Na}$ for water years 2005 to 2007 for USGS station 01104460 were about twice the annual mean yields estimated for water year 1999. This may be the result of greater applications of road salt during the winters of water years 2005 and 2006, which were more severe than the winter of water year 1999.

Milliequivalent ratios of $\mathrm{Na}: \mathrm{Cl}$ for mean annual yields estimated by both methods of calculation for water years 2005 to 2007 indicate that sodium chloride accounts for about 83 percent of the total $\mathrm{Cl}$ load at the primary sampling stations, except at USGS station 01104475 where sodium chloride accounts for about 95 percent of the total $\mathrm{Cl}$ load. This milliequivalent ratio is not necessarily indicative of the deicing compound matrix applied during the study period, particularly for ratios derived from annual loads. Although the movement of $\mathrm{Cl}$ in groundwater is conservative, $\mathrm{Ca}, \mathrm{Na}$, and other cations are affected though cation exchange on mineral surfaces (Millar and Turk, 1949); as a result, groundwater becomes enriched in $\mathrm{Na}$ (relative to most other common ions) as it moves along the flow path. The high $\mathrm{Na}: \mathrm{Cl}$ milliequivalent ratio for USGS station 01104475 may result from the cation exchange process. In comparison to many of the other stations, the drainage basin for this station contains less impervious area; most flow occurs during base-flow conditions (table 15), and as a result, the flow path is long. The long flow path increases the potential for ion exchange resulting in greater concentrations of $\mathrm{Na}$ relative to other cations.

\section{Loads and Yields of Total Nutrients, Water Years 2005 to 2007}

Loads and yields of TN and TP estimated for the primary monitoring stations varied by station. Mean annual yields of $\mathrm{TN}$ estimated for the primary monitoring stations were greater for the tributary subbasins than for the main stem of Stony Brook (USGS station 01104460), which represents most of the flow in the lower Stony Brook Reservoir watershed. Mean annual yields of TN for three of the tributaries (USGS stations 01104415,01104455 , and 01104475 ) were greater than or equal to 1,200 kilograms per square kilometer $\left(\mathrm{kg} / \mathrm{km}^{2}\right)$. The mean annual yield of TN at USGS station 01104433 was lower at $740 \mathrm{~kg} / \mathrm{km}^{2}$. Loads and yields of TN, as well as the other constituents, for this station are potentially underestimated because an undersized or damaged pipe upstream from the monitoring station diverted stormflow to an adjacent unmonitored subbasin. Base-flow and stormflow components of the annual TN load for primary sampling stations were similar (table 14). From 83 to 96 percent of the TP load in the tributaries was associated with stormflow (table 14), and 73 percent of the TP load in Stony Brook (USGS station 01104460) was associated with stormflow. Yields of TP at USGS stations 

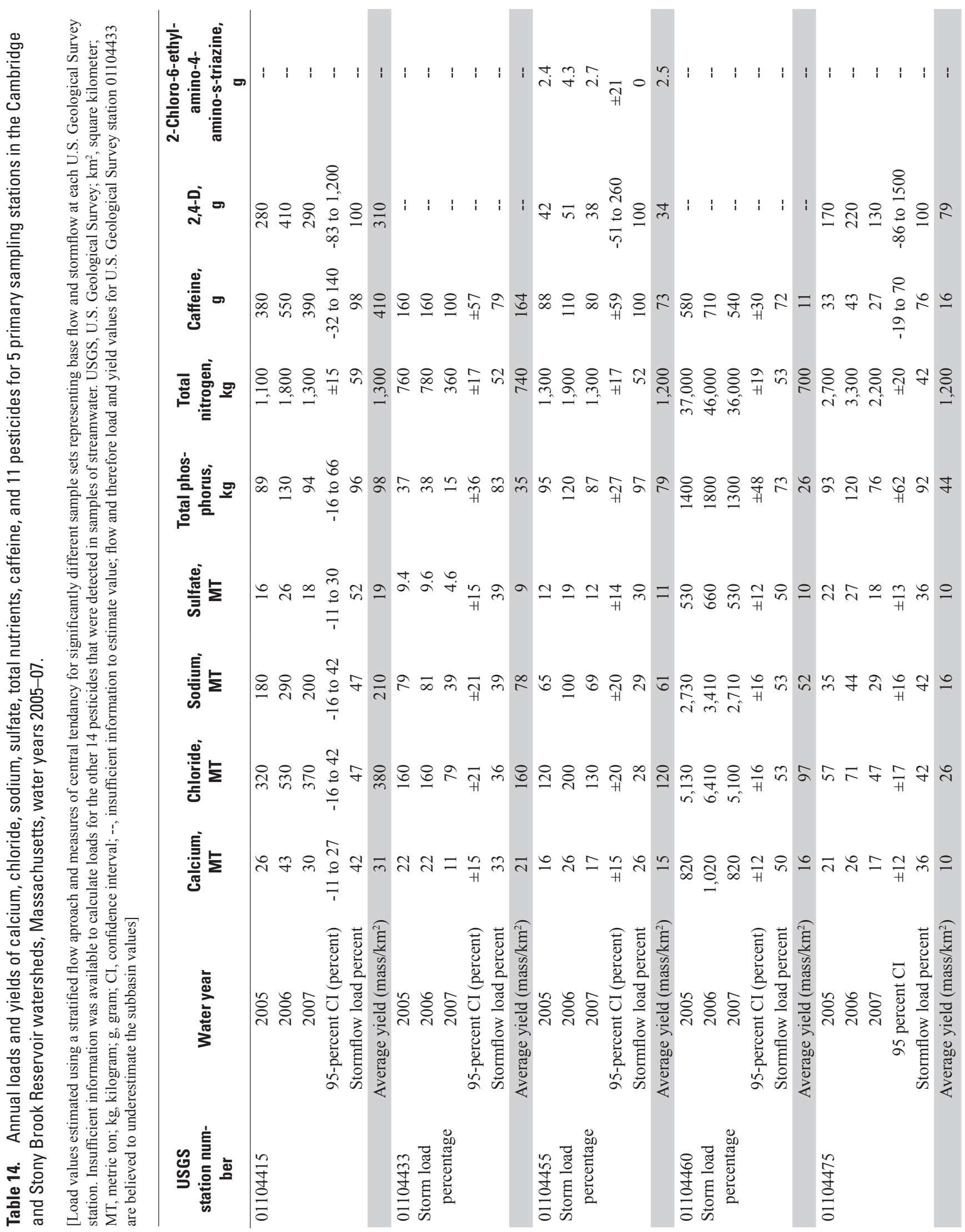


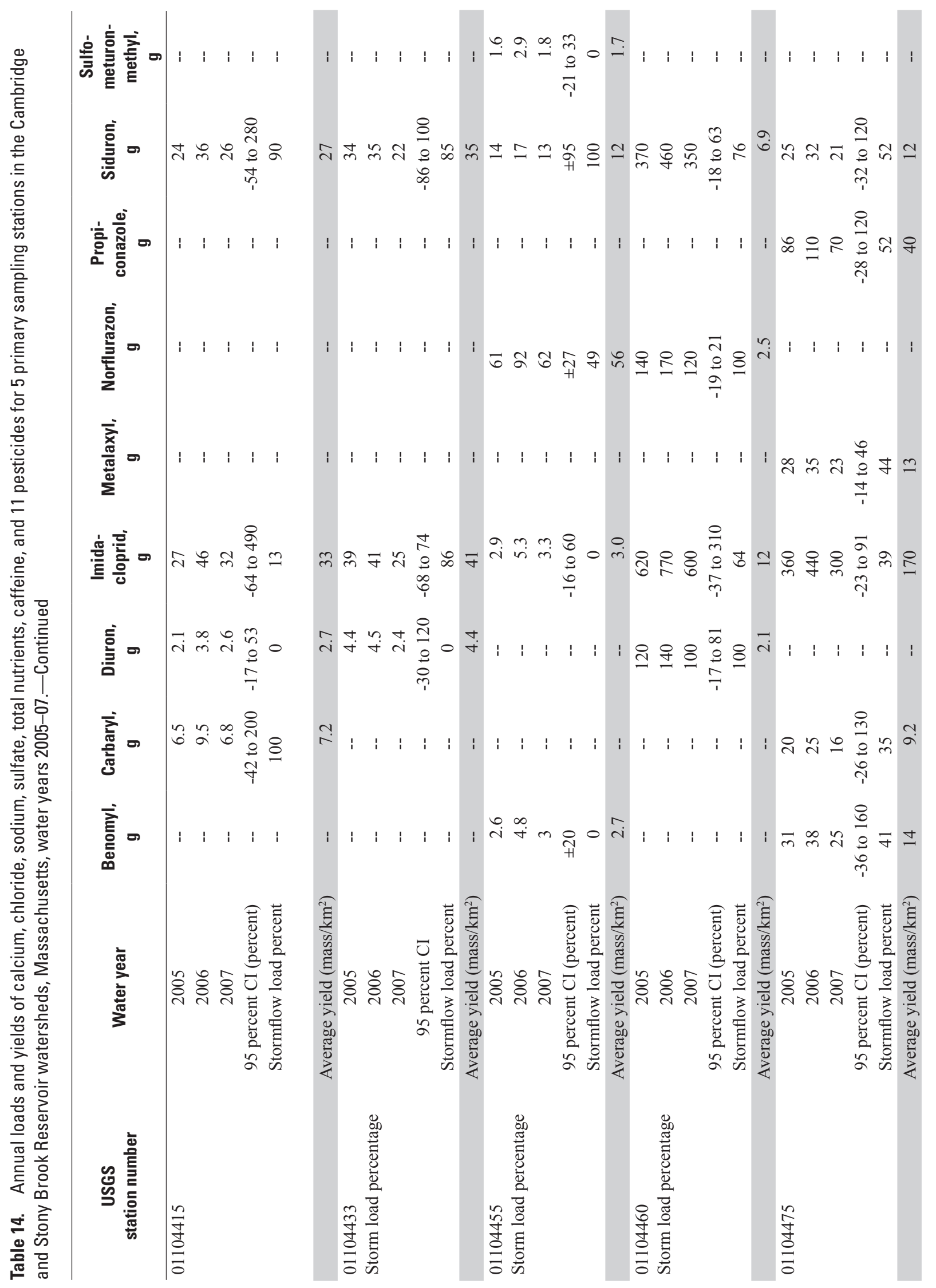


Table 15. Annual mean flow, runoff, and estimated annual loads of calcium, chloride, sodium, and sulfate for sampling stations in the Cambridge and Stony Brook Reservoir watersheds, Massachusetts, water years 1999-2008.

[Load values estimated from continuous records of specific conductance and discharge at each U.S. Geological Survey monitoring station. USGS, U.S. Geological Survey; $\mathrm{ft}^{3} / \mathrm{sec}$, cubic feet per second, MT, metric ton; MT $/ \mathrm{km}^{2}$, metric ton per square kilometer; CI, confidence interval; --, unable to calculate as a result of regulation of discharge; E, estimated]

\begin{tabular}{|c|c|c|c|c|c|c|c|}
\hline \multirow{2}{*}{$\begin{array}{c}\text { USGS } \\
\text { station number }\end{array}$} & \multirow{2}{*}{$\begin{array}{l}\text { Water } \\
\text { year }\end{array}$} & \multirow{2}{*}{$\begin{array}{c}\text { Annual mean } \\
\text { discharge, } \\
\mathrm{ft}^{3} / \mathrm{sec}\end{array}$} & \multirow{2}{*}{$\begin{array}{c}\text { Runoff } \\
\text { percent }\end{array}$} & \multicolumn{4}{|c|}{ Estimated annual load } \\
\hline & & & & $\begin{array}{l}\text { Calcium, } \\
\text { MT }\end{array}$ & $\begin{array}{l}\text { Chloride, } \\
\text { MT }\end{array}$ & $\begin{array}{l}\text { Sodium, } \\
\text { MT }\end{array}$ & $\begin{array}{l}\text { Sulfate, } \\
\text { MT }\end{array}$ \\
\hline \multirow[t]{5}{*}{01104415} & 2004 & 0.77 & E27 & 23 & 260 & 140 & 15.0 \\
\hline & 2005 & 0.82 & 30 & 31 & 370 & 200 & 19.0 \\
\hline & 2006 & 1.1 & 31 & 27 & 310 & 170 & 19.0 \\
\hline & 2007 & 0.8 & 27 & 18 & 190 & 100 & 13.0 \\
\hline & 2008 & 0.95 & 39 & 28 & 330 & 180 & 18.0 \\
\hline 95-percent CI (percent) & & & & \pm 35 & \pm 16 & \pm 22 & \pm 68 \\
\hline Storm load percent & & & & 30 & 31 & 31 & 32 \\
\hline Annual average yield $\left(\mathrm{MT} / \mathrm{km}^{2}\right)$ & & & & 24 & 275 & 149 & 16 \\
\hline \multirow[t]{10}{*}{01104430} & 1999 & 6.1 & -- & 87 & 630 & 340 & 63.0 \\
\hline & 2000 & 8.6 & -- & 140 & 1,150 & 630 & 100 \\
\hline & 2001 & 13 & -- & 230 & 1,980 & 1,080 & 170 \\
\hline & 2002 & 7.0 & -- & 150 & 1,360 & 740 & 100 \\
\hline & 2003 & 11 & -- & 220 & 1,990 & 1,080 & 160 \\
\hline & 2004 & 10 & -- & 210 & 1,870 & 1,010 & 150 \\
\hline & 2005 & 16 & -- & 310 & 2,700 & 1,470 & 220 \\
\hline & 2006 & 12 & -- & 220 & 1,910 & 1,040 & 160 \\
\hline & 2007 & 16 & -- & 280 & 2,250 & 1,220 & 200 \\
\hline & 2008 & 8.1 & -- & 160 & 1,430 & 770 & 110 \\
\hline 95-percent CI (percent) & & & & \pm 20 & \pm 16 & \pm 22 & \pm 68 \\
\hline Storm load percent & & & & -- & -- & -- & -- \\
\hline Annual average yield $\left(\mathrm{MT} / \mathrm{km}^{2}\right)$ & & & & 11 & 97 & 53 & 8 \\
\hline \multirow[t]{3}{*}{1104433} & 2005 & 0.45 & 29 & 27 & 210 & 110 & 10.0 \\
\hline & 2006 & 0.46 & 22 & 17 & 120 & 67.0 & 7.6 \\
\hline & 2007 & 0.29 & 27 & 11 & 81 & 44.0 & 5.2 \\
\hline 95-percent CI (percent) & & & & \pm 48 & \pm 16 & \pm 22 & \pm 68 \\
\hline Storm load percent & & & & 26 & 26 & 26 & 29 \\
\hline Annual average yield $\left(\mathrm{MT} / \mathrm{km}^{2}\right)$ & & & & 21 & 160 & 86 & 9 \\
\hline \multirow[t]{5}{*}{1104455} & 2004 & 0.94 & 42 & 21 & 240 & 130 & 15 \\
\hline & 2005 & 1.1 & 32 & 30 & 420 & 230 & 22 \\
\hline & 2006 & 1.2 & -- & 23 & 220 & 120 & 17 \\
\hline & 2007 & 0.87 & 28 & 16 & 160 & 88 & 12 \\
\hline & 2008 & 1.1 & 37 & 24 & 300 & 160 & 17 \\
\hline 95-percent CI (percent) & & & & \pm 21 & \pm 17 & \pm 23 & \pm 69 \\
\hline Storm load percent & & & & 27 & 35 & 34 & 27 \\
\hline Annual average yield $\left(\mathrm{MT} / \mathrm{km}^{2}\right)$ & & & & 18 & 211 & 115 & 13 \\
\hline
\end{tabular}


Table 15. Annual mean flow, runoff, and estimated annual loads of calcium, chloride, sodium, and sulfate for sampling stations in the Cambridge and Stony Brook Reservoir watersheds, Massachusetts, water years 1999-2008.—Continued

[Load values estimated from continuous records of specific conductance and discharge at each U.S. Geological Survey monitoring station. USGS, U.S. Geological Survey; $\mathrm{ft}^{3} / \mathrm{sec}$, cubic feet per second, MT, metric ton; $\mathrm{MT} / \mathrm{km}^{2}$, metric ton per square kilometer; CI, confidence interval; --, unable to calculate as a result of regulation of discharge; E, estimated]

\begin{tabular}{|c|c|c|c|c|c|c|c|}
\hline \multirow{2}{*}{$\begin{array}{c}\text { USGS } \\
\text { station number }\end{array}$} & \multirow{2}{*}{$\begin{array}{l}\text { Water } \\
\text { year }\end{array}$} & \multirow{2}{*}{$\begin{array}{c}\text { Annual mean } \\
\text { discharge, } \\
\mathrm{ft}^{3} / \mathrm{sec}\end{array}$} & \multirow{2}{*}{$\begin{array}{l}\text { Runoff } \\
\text { percent }\end{array}$} & \multicolumn{4}{|c|}{ Estimated annual load } \\
\hline & & & & $\begin{array}{l}\text { Calcium, } \\
\text { MT }\end{array}$ & $\begin{array}{l}\text { Chloride, } \\
\text { MT }\end{array}$ & $\begin{array}{l}\text { Sodium, } \\
\text { MT }\end{array}$ & $\begin{array}{c}\text { Sulfate, } \\
\text { MT }\end{array}$ \\
\hline \multirow[t]{6}{*}{1104460} & 2003 & 40 & -- & 710 & 4,470 & 2,430 & 430 \\
\hline & 2004 & 37 & -- & 620 & 3,800 & 2,070 & 380 \\
\hline & 2005 & 47 & -- & 830 & 5,250 & 2,860 & 510 \\
\hline & 2006 & 59 & -- & 910 & 5,370 & 2,930 & 570 \\
\hline & 2007 & 47 & -- & 730 & 4,320 & 2,360 & 450 \\
\hline & 2008 & 42 & -- & 670 & 4,070 & 2,220 & 420 \\
\hline 95-percent CI (percent) & & & & \pm 30 & \pm 16 & \pm 22 & \pm 68 \\
\hline Storm load percent & & & & -- & -- & -- & -- \\
\hline Annual average yield (MT/km²) & & & & 13 & 80 & 43 & 8 \\
\hline \multirow[t]{4}{*}{1104475} & 2005 & 1.45 & 11 & 22 & 60 & 37 & 23 \\
\hline & 2006 & 1.8 & 13 & 22 & 57 & 36 & 22 \\
\hline & 2007 & 1.2 & 11 & 14 & 37 & 24 & 15 \\
\hline & 2008 & 1.4 & 15 & 24 & 72 & 42 & 26 \\
\hline 95-percent CI (percent) & & & & \pm 35 & \pm 27 & \pm 22 & \pm 49 \\
\hline Storm load percent & & & & 13 & 13 & 13 & 13 \\
\hline Annual average yield $\left(\mathrm{MT} / \mathrm{km}^{2}\right)$ & & & & 9.3 & 26 & 16 & 9.7 \\
\hline
\end{tabular}


01104415 and 01104455 were about three times greater than the yield for most of the drinking-water source area (USGS station 01104460). The high yields at these stations are likely the result of the tributaries receiving stormflow directly from large impervious areas despite weak to moderate correlations between TP and impervious areas at the primary sampling stations, which undoubtedly are affected by the underestimate of the TP yield for the drainage area of USGS station 01104433.

Annual yields of TN estimated for water year 1998 at USGS stations 01104415, 01104455, 01104460, and 01104475 (Waldron and Bent, 2001) were similar (within about 24 percent) to the respective mean annual yields estimated in this study. However, yields of TP at the same USGS stations for water years 2005 to 2007 were about three or more times greater than the yields estimated for water year 1998. In the case of USGS station 01104415 , the estimated mean annual load was about 14 times greater than the load reported for water year 1998. The differences between annual yields estimated at these USGS stations may be explained, in part, by differences in sample collection. In the prior study (Waldron and Bent, 2001), discrete samples of streamwater were collected primarily during base-flow conditions and to a lesser extent during stormflows. In general, concentrations of TP collected during base flow were similar in both studies. However, the TP concentrations in samples of base flow and stormflow collected as part of this study were significantly different (TP during stormflow was often an order of magnitude higher than during base flow). In the absence of detailed stormflow data, it is likely that the preponderance of base-flow samples collected during the 1998 study led to underestimated TP loads.

\section{Loads and Yields of Selected Pesticides and Caffeine, Water Years 2005 to 2007}

Loads and yields of 11 pesticides and caffeine were estimated for stations having frequent detections of these analytes. Data were insufficient to estimate pesticide loads and yields of the remaining 14 pesticides because they were either not detected or infrequently detected. Load and yield estimates for the five primary sampling stations were variable for pesticides and caffeine (table 14). Annual mean loads of individual pesticides were less than a kilogram at all stations. The highest yields were estimated for the herbicide 2,4-D and the insecticide imidacloprid, ranging from 34 to $310 \mathrm{~g} / \mathrm{km}^{2}$ and 3 to $170 \mathrm{~g} / \mathrm{km}^{2}$, respectively. The load for 2,4-D was entirely associated with stormflow. The largest load and yield for 2,4-D were estimated for USGS station 01104415 in the Cambridge Reservoir watershed. The highest yields for imidacloprid, benomyl, carbaryl, metalaxyl, and propiconazole were estimated for USGS station 01104475 on a tributary that drains directly into the Stony Brook Reservoir. Annual yields for the herbicide siduron ranged from 6.9 to $35 \mathrm{~g} / \mathrm{km}^{2}$ with most of the loads associated with stormflow, during which it likely adsorbed to suspended sediment, based upon its low aqueous solubility and sorption coefficient (Koc).
Mean annual yields for the insecticide diuron ranged from 2.1 to $4.4 \mathrm{~g} / \mathrm{km}^{2}$, and the highest yield was estimated for USGS station 01104433 on a tributary to Hobbs Brook south of the Cambridge Reservoir. Mean annual yield estimates for caffeine ranged from 11 to $410 \mathrm{~g} / \mathrm{km}^{2}$ among the five primary monitoring stations. Caffeine was primarily transported during stormflow. The estimated annual load of caffeine to the Stony Brook Reservoir (summation of loads for USGS station 01104460 and 01104475 ) is equivalent to about 6,500 12-ounce cups of coffee, assuming an average cup of coffee contains about $346 \mathrm{mg} / \mathrm{L}$ of caffeine (Seiler and others, 1999).

\section{Accuracy of Estimated Loads}

The accuracy of annual load and yield estimates in this study is affected by errors associated with sample collection and processing techniques, analytical techniques, and estimation of the central tendency for each constituent concentration as related to the size of each dataset and the range of measured conditions of flow and constituent concentrations. In addition, the accuracy of annual loads estimated from continuous records of streamflow and specific conductance is affected by the accuracy and range of measured conditions of flow and specific conductance, and the accuracy of the relations between specific conductance and the constituent concentrations.

Concentration errors or bias can vary from sample to sample on the basis of the uniformity of the constituent concentration throughout the stream and method of sample collection. Typically, less error is associated with dissolved constituents that tend to be more evenly distributed throughout the water column than with constituents such as $\mathrm{P}$, which tend to be associated with suspended sediment. Concentration error also can result during sample processing from contamination, non-uniform sample splitting, and sample degradation. Analytical-method errors often vary with concentration of the constituent: smaller concentrations near the detection level of the method are often less accurate than concentrations greater than the laboratory reporting level. Concentrations of major ions and total nutrients measured in this study were greater than the laboratory reporting limits. However, many concentration values for pesticides were low and often reported as estimated values or were less than the analytical detection limit. As discussed earlier, the accuracy and precision of constituent concentration data are measured on the basis of the collection of field blank, replicate, and spike samples.

Loads are calculated from streamflow and concentration data. Therefore, the accuracy of streamflow records affects the accuracy of load estimates. The USGS rates the accuracy of streamflow records on the basis of the performance of the water-level recorder, the accuracy and range of discharge measurements, and the stability of the stage-discharge relation at a given station. Accuracy ratings assigned to streamflow records may vary over time or range of flow and indicate the difference between the computed and true values of discharge 
(Kennedy, 1983). For example, a USGS rating of "good" indicates that 95 percent of the daily streamflow values are within 5 to 10 percent of the true values. In general, most continuous records of streamflow collected in the drinking-water source area have mean errors at the 95-percent confidence limit of \pm 5 to 10 percent (U.S. Geological Survey, 2009). Base-flow samples were collected throughout each water year and generally represent the annual range of base-flow stream conditions. The stage-discharge relation for base-flow conditions typically was well defined; however, the stage-discharge relation often was extrapolated beyond the range of the highest streamflow measurements, and as a result, uncertainty is generally greater for constituent load estimates for extreme flow events.

The relative accuracy of load data reported in tables 14 and 15 is inclusive of available quality-control data. The mean-square-error propagation method (Harmel and others, 2006) was used to estimate the 95-percent confidence interval about the load estimates. This method treats potential errors as bidirectional as opposed to additive. It combines all available estimates of error for streamflow, sample precision, and estimates of constituent population means or regression estimates to produce realistic estimates of overall error. For many constituents, the error is not normally distributed around the load estimate but is asymmetrical and skewed to the positive side as a result of the statistics of the available concentration data. Loads of major ions estimated from continuous records of flow and specific conductance, particularly loads for $\mathrm{Cl}$ and $\mathrm{Na}$, are more accurate than loads estimated using the stratified approach. This is because the specific conductance measurements completely cover the range of field conditions, and the accuracy of the relation of the concentrations of major ions to measured specific conductance is better than the variance about the mean concentration data at each station (table 7).

Loads and yields for USGS station 01104433 are potentially underestimated because stormflow often was constricted by an undersized or damaged pipe upstream from the station. As a result, some portion of stormwater was diverted into an adjacent unmonitored subbasin. Therefore, loads reported for USGS station 01104433 are valid only for the location of the monitoring station rather than for the entire subbasin, and as such, yields cannot be accurately estimated for this station. Loads and yields are potentially underestimated by a factor of two on the basis of annual streamflow yields in comparison to those for adjacent subbasins (Smith, 2011). Because interbasin flow is primarily associated with stormflow, the bias in loads and yields for constituents with different concentrations during base flow and stormflow is potentially greater. In such cases, the relations between constituents and land-use classes potentially are stronger and significant when loads are doubled for this station. For example, strong significant relations result between total roadway area and P yields for the subbasin when the P yield for USGS station 01104433 is doubled.

\section{Chloride and Sodium Trends}

Intermittent measurements of $\mathrm{Cl}$ and $\mathrm{Na}$ concentrations over the last few decades indicate that the respective concentrations in water from Cambridge Reservoir are increasing. The mean concentration of $\mathrm{Na}$ in water released from the Cambridge Reservoir during 1967-83 was about 43 mg/L (Geotechnical Engineers, Inc., 1985 ). The mean concentration of $\mathrm{Na}$ in water released from the Cambridge Reservoir in 1985 was $51 \mathrm{mg} / \mathrm{L}$ (Geotechnical Engineers, Inc., 1985 ), and the median $\mathrm{Na}$ concentration in samples collected at the outlet of the reservoir during 1997-98 was $64 \mathrm{mg} / \mathrm{L}$ (Waldron and Bent, 2001). From water year 1999 to water year 2008, annual flow-weighted concentrations of $\mathrm{Na}$ in water released from the Cambridge Reservoir were estimated from records of flow and specific conductance and ranged from 63 to $113 \mathrm{mg} / \mathrm{L}$.

During dry years, annual mean concentrations of $\mathrm{Cl}$ and $\mathrm{Na}$ are likely to increase assuming that natural and anthropogenic inputs of the constituents are similar from year to year. In contrast, concentrations tend to decrease during wet years under the same circumstances. Therefore, time trends for annual loads of $\mathrm{Cl}$ and $\mathrm{Na}$, which are more resistant to shifts related to differences in annual precipitation than are concentrations, were investigated for the 11-year period of water years 1998 to 2008 at USGS streamgages 01104430 at the outlet of the Cambridge Reservoir and 01104460 on Stony Brook above Stony Brook Reservoir. Although an upward trend in $\mathrm{Na}$ concentration since 1967 is apparent from historical sample data collected from the outlet of the Cambridge Reservoir, results of Mann-Kendall tests on available annual load data for water years 1998 to 2008 for $\mathrm{Cl}$ and $\mathrm{Na}$ at each USGS station show that the trend is not significant ( $p$-value $>0.05$ ). The lack of significance in these results is likely the consequence of dissimilar levels of annual input for each constituent related to the severity of the winters during the period of study.

To overcome the shortcomings of the initial data used in the trend test, a Mann Kendall test with a LOWESS adjustment of load data using annual winter weather severity index (WWSI) values was performed. WWSIs are commonly used to relate winter weather conditions to effects on wildlife (Michigan Department of Natural Resources Wildlife Division, 2010) and recently were used to relate winter weather conditions to winter-maintenance expenditures and winter-roadway accident rates (Maze and others, 2007). For this study, WWSI values were calculated as described by Boselly and others (1993) using daily minimum and maximum measurements of air temperature made at USGS station 01104430 and annual total snowfall data collected in the Cambridge Reservoir watershed and obtained from the Massachusetts Department of Transportation (Brett Loosian, Massachusetts Department of Transportation, written commun., 2011). Annual snow totals for Boston, Mass., obtained from the National Weather Service (2011), were used prior to water year 2004. In general, a low (negative value) WWSI indicates a severe winter, and a high value (positive value) indicates a mild winter season. Correlations between WWSIs and annual loads of $\mathrm{Na}$ at USGS 

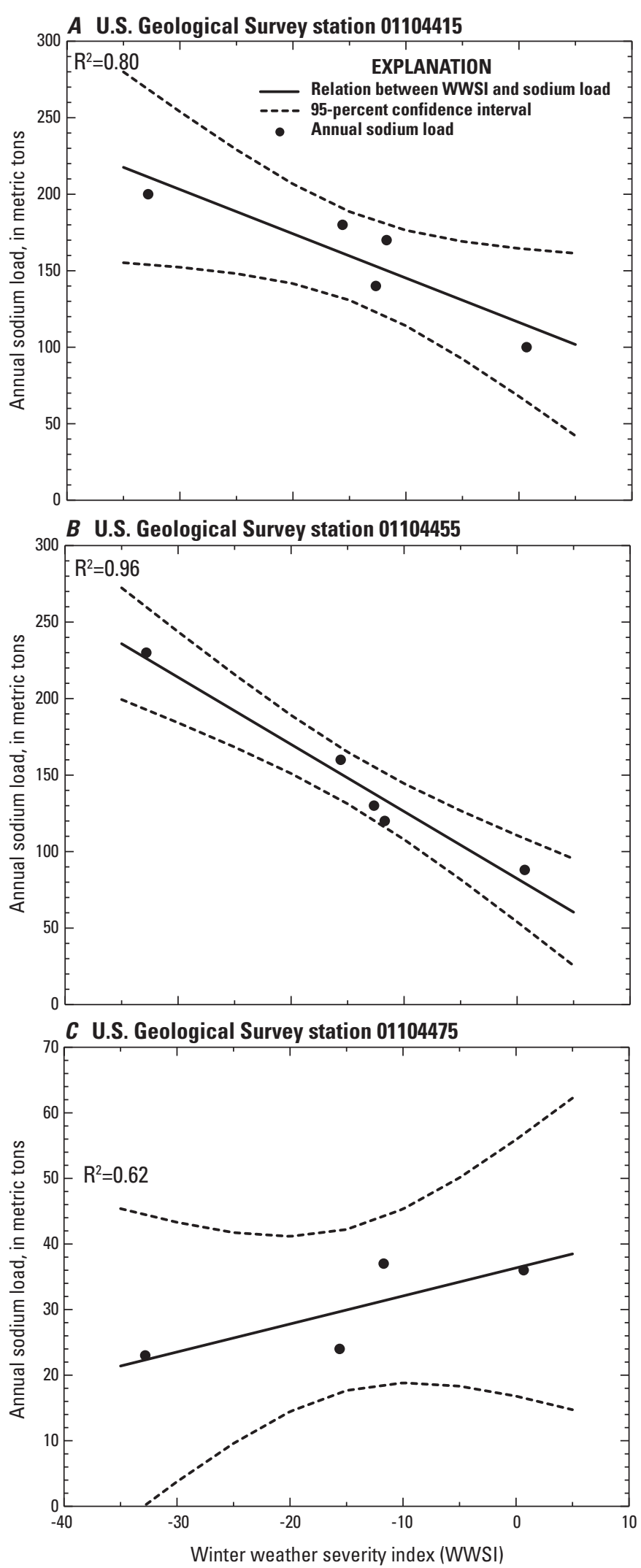

Figure 20. Relation of winter weather severity to annual sodium loads for U.S. Geological Survey stations $A, 01104415, B$, 01104455, and $C, 01104475$, Cambridge drinking-water source area, Massachusetts, water years 2004-08. stations 01104415 and 01104455 , which received runoff from relatively large areas of roadway (table 2), were moderately strong to strong (fig. 20). Similar correlations were found between annual $\mathrm{Cl}$ loads and WWSI values. These correlations indicate that deicing compounds containing $\mathrm{Cl}$ and $\mathrm{Na}$ are applied methodically on roadway surfaces in these two subbasins. These relations also indicate that a large portion of $\mathrm{Cl}$ and $\mathrm{Na}$ that infiltrates to the groundwater is likely discharged to surface water within the same water year, at least for these small subbasins. Mann Kendall tests using a LOWESS adjustment $(\mathrm{f}=0.5)$ of load data on the basis of annual WWSIs for USGS station 01104430 indicated a significant upward trend for both $\mathrm{Cl}(\mathrm{p}=0.02)$ and $\mathrm{Na}(\mathrm{p}=0.04)$. Results for similar Mann Kendall tests on data for USGS station 01104460 were not significant, indicating that the bulk of $\mathrm{Cl}$ and $\mathrm{Na}$ loads (including those loads from the Cambridge Reservoir) transported to the Stony Brook Reservoir did not change during the test period.

The upward trend in $\mathrm{Cl}$ and $\mathrm{Na}$ loads at the outlet of the Cambridge Reservoir (USGS station 01104430) is difficult to explain in the absence of a more complete spatial data set for the Cambridge Reservoir watershed. Previous data (Waldron and Bent, 2001) indicate that USGS station 01104415 has the greatest $\mathrm{Cl}$ and $\mathrm{Na}$ yields of any subbasin within the Cambridge Reservoir watershed; however, this station accounts for only about 6 percent of the area and about 14 percent of the roadway of the entire watershed. Although the application rates for deicing compounds containing $\mathrm{Cl}$ and $\mathrm{Na}$ are expected to be similar for roadway surfaces throughout the watershed, the movement of these ions to tributaries may be slower in some subbasins where roadway runoff is not directly discharged to the receiving tributary or reservoir water. This delay between the time of application of deicing compounds and movement into the reservoir may result as roadway and parking lot runoff infiltrates into the ground adjacent to the pavement or is diverted to settling ponds or other structural best-management practices where it infiltrates to the groundwater. Consequently, some portion of the load of $\mathrm{Cl}$ and $\mathrm{Na}$ per water year estimated for the outlet of the Cambridge Reservoir may include loads from one or more of the other subbasins from prior water years.

The upward trend in $\mathrm{Cl}$ and $\mathrm{Na}$ loads estimated for the outlet of the Cambridge Reservoir (USGS station 01104430) cannot be explained on the basis of existing information from the single upstream monitoring station. Results from a Mann Kendall test indicate that there is no significant trend in winter severity from 1999 to 2008, thus the increase in $\mathrm{Cl}$ and $\mathrm{Na}$ loads is not attributed to progressively worse winter weather during this period. Annual $\mathrm{Cl}$ and $\mathrm{Na}$ loads for water years 2004 to 2008 at USGS stations 01104415 and 01104455 were well correlated with WWSI values. This correlation indicates that deicing compounds were applied in a manner consistent with annual weather conditions and that the annual applications of the deicing compounds are likely reflected in the annual loads for the same water year for these small subbasins. In the absence of additional data, the trend may be explained, 
in part, by increased loads in one or more of the unmonitored subbasins associated with either increased applications of salt or with retarded groundwater discharge of $\mathrm{Cl}$ and $\mathrm{Na}$ from applications of deicing compounds in previous severe winters.

\section{Summary}

The city of Cambridge, Massachusetts, Water Department (CWD) obtains its raw water from a system of three primary storage reservoirs. Except for Fresh Pond Reservoir, the drinking-water source area for these reservoirs is outside the city of Cambridge in parts of the towns of Lexington, Lincoln, and Weston and the city of Waltham. The Cambridge drinkingwater source area encompasses major transportation corridors, as well as large areas of industrial, commercial, and residential land use, and as a result, the drinking-water source area is potentially at risk from a variety of contaminants. Continuousmonitoring data collected by the U.S. Geological Survey (USGS) since water year 1998 and water samples collected during base-flow and stormflow conditions from water years 2004 to 2008 are used to identify current water-quality conditions, estimate loads and yields, and where sufficient data are available, describe trends in streamwater quality. These data also establish a baseline for future comparisons. These data can be used to determine how streamwater quality is affected by various watershed characteristics and to provide information that can be used to guide future watershed management.

Physical properties and concentrations of calcium $(\mathrm{Ca})$, chloride $(\mathrm{Cl})$, sodium $(\mathrm{Na})$, sulfate $\left(\mathrm{SO}_{4}\right)$, total nutrients, selected polar pesticides, and caffeine were measured in 15 to 16 samples of base flow and 15 composite samples of stormflow collected at four USGS sampling stations on tributaries to the Cambridge and Stony Brook Reservoirs. An additional 12 samples were collected from Stony Brook (USGS station 01104460), the primary stream to the Stony Brook Reservoir representing the major part of the flow for the entire drinkingwater source area. These five USGS stations are the primary sampling stations. Three samples, analyzed for the same properties and constituents, were collected from each of six additional tributaries during base-flow conditions. Samples also were collected periodically from the raw-water intake at the Fresh Pond Reservoir in Cambridge, Massachusetts. These additional locations are the secondary sampling locations. Finally, concentrations of $\mathrm{Ca}, \mathrm{Cl}, \mathrm{Na}$, and $\mathrm{SO}_{4}$ were estimated on the basis of relations between continuous records of specific conductance and concentration data on the respective ions at six continuous-monitoring stations, including the five primary sampling stations and the secondary sampling station at the outlet of the Cambridge Reservoir (USGS station 01104430).

Concentrations of dissolved $\mathrm{Ca}, \mathrm{Cl}, \mathrm{Na}$, and $\mathrm{SO}_{4}$ in samples collected from the tributaries throughout the drinkingwater source area varied widely, particularly in the small subbasins where the effects of stormwater runoff and land development increase. The median concentrations for $\mathrm{Ca}, \mathrm{Cl}$, $\mathrm{Na}$, and $\mathrm{SO}_{4}$ in samples collected in the Hobbs Brook Basin were 39.8, 392, 207, and 21.7 milligrams per liter (mg/L), respectively, and the median concentrations for the tributaries in the Stony Brook Reservoir watershed were lower at 17.8, 87.7, 49.7, and $14.7 \mathrm{mg} / \mathrm{L}$, respectively. Median concentrations in the main stem of Stony Brook were 19.5, 126, 65.8, and $12.4 \mathrm{mg} / \mathrm{L}$, respectively, indicating appreciable dilution of high-concentration water released from the Cambridge Reservoir by streamflow containing low concentrations of dissolved ions from the less developed upper Stony Brook Reservoir watershed. Concentrations of $\mathrm{Ca}, \mathrm{Cl}, \mathrm{Na}$, and $\mathrm{SO}_{4}$ in samples collected in the tributaries of the drinking-water supply area were negatively correlated with streamflow. As a result, the concentrations of major ions in tributaries tend to increase during the summer when streamflow is low and decrease during high base-flow conditions and stormflows (even during storms that occur in the winter and contain high initial concentrations of dissolved ions). This pattern indicates that groundwater is an important source for the major ions. The high concentrations of $\mathrm{Cl}$ and $\mathrm{Na}$ in base flow often were greater than the U.S. Environmental Protection Agency (USEPA) Secondary Drinking-Water Regulation (SDWR) for $\mathrm{Cl}$ and the Commonwealth of Massachusetts, Executive Office of Energy and Environmental Affairs, Department of Environmental Protection, Water, Wastewater \& Wetlands: Regulations \& Standards (MassEOEEA) drinking-water guideline for $\mathrm{Na}$. Concentrations of $\mathrm{Cl}$ estimated from continuous records of specific conductance routinely exceeded the USEPA criterion continuous concentration (CCC) and SDWR during base-flow conditions in the tributaries at USGS stations 01104415, 01104433, and 01104455. Flow-weighted values of specific conductance associated with stormflows exceeded specific conductance levels estimated at the concentrations for the USEPA SDWR and CCC thresholds for $\mathrm{Cl}$ less often than specific conductance during base flow; however, instantaneous measurements of specific conductance during the beginning of many winter runoff events were substantially greater than the maximum measurements of specific conductance during base flow. Specific conductance at USGS station 01104475, which drains a large residential area, rarely exceeded the specific conductance levels estimated at the USEPA SDWR for $\mathrm{Cl}$. About 6 percent of the daily mean specific conductance values in water released from the Cambridge Reservoir were greater than the specific conductance levels estimated at the SDWR and CCC thresholds; the estimated CMC threshold was not exceeded during water years 2004 to 2008. Specific conductance data in the main stem of Stony Brook (USGS station 01104460) were rarely (less than 0.5 percent) greater than the specific conductance levels estimated at the SDWR and CCC thresholds. Concentrations of dissolved $\mathrm{Na}$ in water samples collected throughout the drinking-water supply area, as well as from the raw-water intake at the Fresh Pond Reservoir, routinely exceeded the MassEOEEA drinking-water guideline. Only in a few composite samples of stormflow was the concentration of $\mathrm{Na}$ less than the guideline. 
Concentrations of total nitrogen (TN) and total phosphorus (TP) in samples collected from the tributaries throughout the drinking-water source area were affected by streamflow volume, stormwater runoff, and land use in each subbasin. The median concentrations for TN and TP in all samples collected in the Hobbs Brook Basin were 1.48 and $0.04 \mathrm{mg} / \mathrm{L}$, respectively, whereas the median concentrations for TN and TP in the tributary streams in the Stony Brook Reservoir watershed were 1.52 and $0.03 \mathrm{mg} / \mathrm{L}$, respectively. Correlations between concentrations of TN and flow were weak, indicating that flow does not explain the observed variability in the TN concentrations. In contrast, concentrations of TP were positively correlated with flow, and the relation was statistically significant at three of the five primary sampling stations.

Water samples collected in the drinking-water source area and samples of raw water collected from the Cambridge water-treatment facility intake at the Fresh Pond Reservoir were analyzed for concentrations of caffeine and 59 different pesticides. For all samples collected during the study, 34 of the 59 pesticides were not detected, 25 pesticides had at least one detection, and 9 of the 25 pesticides were detected at an overall frequency greater than 15 percent. Only 12 pesticides were detected in base flow and (or) stormflow samples at a frequency equal to or greater than 25 percent at one or more of the 5 primary sampling stations. Most of these pesticides are found in over-the-counter products used for turf management and the treatment of ornamental shrubs. Many pesticides were detected in both base flow and stormflow. The regular detection of pesticides in base flow, particularly those with high aqueous solubility, is an indication of local groundwater contamination. Imidacloprid, norflurazon, and siduron were the most frequently detected pesticides in samples of water collected in the drinking-water source area, with the number of detections ranging from about 24 to 41 percent. The range of concentrations for 2,4-D, norflurazon, siduron, imidacloprid, carbaryl, and caffeine were generally similar for Cambridge and Stony Brook Reservoir watersheds; diuron was the exception with concentrations generally lower in the Cambridge Reservoir watershed. Although a mixture of different pesticides is transported to the Cambridge Reservoir, diuron, norflurazon, and siduron were the only pesticides detected in samples collected at the outlet of the reservoir, indicating that other pesticides potentially degrade during the relatively long retention time in the reservoir (greater than 7 months). Compounds with a long aqueous half life, particularly norflurazon and siduron, are able to advance though the entire reservoir system. Compared to the Cambridge Reservoir retention time, the retention time for the Stony Brook Reservoir is comparatively short, less than about 2 weeks, thus even pesticides with a relatively short aqueous half life are able to persist in waters directed to the Fresh Pond Reservoir. Although six different pesticides were detected in samples from the Fresh Pond Reservoir raw-water intake, carbaryl was the only compound detected at greater than the long-term method detection level (LTMDL). Caffeine also was detected at greater than the LTMDL. Caffeine was detected in about 64 percent of 171 water samples collected throughout the drinking-water source area at concentrations ranging from 0.003 to $1.82 \mu \mathrm{g} / \mathrm{L}$.

Annual loads and yields of major ions, total nutrients, selected pesticides, and caffeine were estimated for the five primary sampling stations using (1) a stratified flow approach and a measure of the central tendency of each sample set and (2) continuous records of streamflow and specific conductance and the relation between ion concentration and specific conductance. Annual loads and mean annual yields for $\mathrm{Ca}, \mathrm{Cl}$, $\mathrm{Na}$, and $\mathrm{SO}_{4}$ calculated from continuous records of specific conductance were generally similar to those calculated on the basis of mean concentration data. These annual loads and mean annual yields from continuous records were expected to be more accurate than those estimated from sample concentrations because specific conductance was based on a data set that encompasses all base-flow conditions and runoff events, including snow melts. Mean annual yields of $\mathrm{Ca}, \mathrm{Cl}, \mathrm{Na}$, and $\mathrm{SO}_{4}$ for the drinking-water source area for water years 2005 to 2007 , estimated on the basis of continuous records of specific conductance, were $14,85,46$, and 9 metric tons per square kilometer, respectively. Mean annual yields of most major ions at USGS stations 01104415, 01104433, and 01104455 were substantially higher than the mean annual yields for the drinking-water source area. These stations are in subbasins that contain large areas of roadways and parking lots and land-use classes that have moderately strong correlations with annual flow-weighted concentrations of $\mathrm{Cl}$ and $\mathrm{Na}$. About 30 percent of the loads of each major ion at each of the tributaries was associated with stormflow, except for USGS station 01104475 where less than 30 percent of loads was attributable to stormflow.

Mean annual yields of TN in the tributaries ranged from about 740 to more than 1,200 kilograms per square kilometer $\left(\mathrm{kg} / \mathrm{km}^{2}\right)$, which were greater than the mean annual yields for most of the drinking-water source area. The proportion of the calculated annual TN load was similar in base flow and stormflow. In contrast, more than 83 percent of the TP load in the tributaries and about 73 percent of the TP load in the main stem of Stony Brook (USGS station 01104460) was associated with stormflow. Yields of TP at USGS stations 01104415 and 01104455 were about three times greater than the yields for most of the drinking-water source area. Correlations between annual flow-weighted concentrations of TN collected at four primary sampling stations on the tributaries, and percentages of recreational area and open water, were significant. Correlations of mean concentrations of TN in base flow with commercial landscaping, interstate highway, state highway, and total impervious land uses were significant. Mean concentrations of $\mathrm{TN}$ in base flow were negatively correlated with wetland land use. Correlations between annual flow-weighted concentrations of TP and percentages of forest and State highway land uses were moderately strong; however, the relations were significant only at a lower confidence interval (p-value 0.13 ). Significant negative correlations were found between annual flow-weighted concentrations of TP and wetland land use. 
Annual loads of individual pesticides were less than 1 kilogram at each of the five primary sampling stations. The highest pesticide yields were estimated for the herbicides 2,4-D and imidacloprid and ranged from 34 to 310 grams per square kilometer $\left(\mathrm{g} / \mathrm{km}^{2}\right)$ and 3 to $170 \mathrm{~g} / \mathrm{km}^{2}$, respectively. The load for 2,4-D was entirely associated with stormflow, and annual flow-weighted concentrations of 2,4-D correlated significantly with the residential roof land uses. The largest load and yield for 2,4-D were estimated for USGS station 01104415 in the Cambridge Reservoir watershed, where the footprint area of residential land use accounts for about 40 percent of the land uses in the subbasin. The highest yields for imidacloprid, benomyl, carbaryl, metalaxyl, and propiconazole were estimated for USGS station 01104475, a tributary to the Stony Brook Reservoir draining a largely residential subbasin. Significant positive correlations were found between recreation area land use and annual flow-weighted concentrations and maximum concentrations of benomyl, imidacloprid, and carbaryl in base flow.

Yields for the herbicide siduron ranged from 6.9 to $35 \mathrm{~g} / \mathrm{km}^{2}$ at the five primary sampling stations, and loads were predominantly associated with stormflow. Positive correlations between annual flow-weighted concentrations of siduron were significant only for wetland land use; however, positive correlations between maximum concentrations of the herbicide in base flow and commercial and total impervious land uses were significant throughout the drinking-water supply area. Mean annual yields for the herbicide diuron ranged from 2.1 to $4.4 \mathrm{~g} / \mathrm{km}^{2}$, and annual flow-weighted concentrations strongly correlated with parking lot land use. The highest yield was measured at USGS station 01104433, a tributary in the Hobbs Brook Basin that contains large areas of commercial development.

Yields of caffeine ranged from 11 to $410 \mathrm{~g} / \mathrm{km}^{2}$ for the five primary sampling stations. Most correlations between annual flow-weighted concentrations of caffeine in samples collected at the primary sampling stations and subbasin landuse classes were weak; however, maximum base-flow concentrations of caffeine in eight subbasins correlated significantly with parking lot land use throughout the drinking-water supply area. Although leaking sewer lines are typical sources of caffeine, the compound is common in various beverages, and associated containers are found on or near roadways and parking lots.

Results of Mann Kendall tests of annual $\mathrm{Cl}$ and $\mathrm{Na}$ loads in Hobbs Brook (USGS station 01104430; the outlet of the Cambridge Reservoir) for water years 1998-2008 with a LOWESS adjustment using the winter weather severity index (WWSI) indicate a significant upward trend. Results of similar tests of available load data for the main stem of Stony Brook (USGS station 01104460) were not significant, indicating no statistical trend in either direction. The upward trend in annual $\mathrm{Cl}$ and $\mathrm{Na}$ loads estimated at the outlet of the Cambridge

Reservoir (Hobbs Book) is difficult to explain on the basis of existing information from the single upstream station. Results from a Mann Kendall test indicate that there was no significant trend in winter severity from 1999 to 2008, thus the increases in $\mathrm{Cl}$ and $\mathrm{Na}$ loads are not necessarily attributable to progressively worse winter weather during this period. Correlations between $\mathrm{Na}$ loads estimated for two tributaries that receive stormwater runoff from large roadway areas (USGS stations 01104415 and 01104455 ) and WWSI values are moderately strong to strong. This correlation indicates that deicing compounds are applied in a manner consistent with annual weather conditions and that the annual application of the deicing compounds is likely reflected in the annual loads for the same water year for these small subbasins. In the absence of additional data, the trend may be explained, in part, by increased loads in one or more of the other unmonitored subbasins associated with either increased applications of salt or with retarded groundwater discharge of $\mathrm{Cl}$ and $\mathrm{Na}$ resulting from applications of deicing compounds in previous severe winters.

Data collection activities in the drinking-water source area are important for effective management and protection of the drinking-water supply. These data enhance the understanding of the physical, chemical, and biological state of the water supply. Without accurate information on the past and current condition of the water supply, effective preservation and remediation programs cannot be implemented or evaluated. The data presented in this report represent the quality of water throughout the drinking-water source area, with a focus on the base-flow and stormflow conditions of four tributaries and the primary stream to the Stony Brook Reservoir for water years 2005 to 2007 . These data indicate the importance of an integrated sampling strategy for accurate assessments of many constituents. Load and yield data estimated as part of this study may serve as benchmarks for future comparisons, particularly pesticide data that historically have not been collected within the watersheds.

\section{References Cited}

American Public Health Association, 1998, Standard methods for the examination of water and wastewater (20th ed.): Washington, D.C., American Public Health Association, American Water Works Association, and Water Environment Federation, p. 3-37-3-43.

Anderson, C.W., 2004 (2d ed.), Turbidity, in Wilde, F.D., Radtke, D.B., eds., Field measurements: U.S. Geological Survey Techniques of Water-Resources Investigations, book 9, chap. A6.7, 64 p., accessed April 7, 2005 at http://water. usgs.gov/owq/FieldManual/Chapter6/6.7_contents.html.

Bedient, P.B., and Huber, W.C., 2002, Hydrology and floodplain analysis ( $3 \mathrm{~d}$ ed.): New Jersey, Prentice Hall, 692 p. 
Boselly III, S.E., Thornes, J.E., Ulberg, C., and Ernst, D.D., 1993, Road weather information systems, Volume 1:

Research Report Report SHRP-H-350: Washington, D.C., Strategic Highway Research Program, National Research Council, 219 p.

Breault, R.F., Smith, K.P., and Sorenson, J.R., 2005, Residential street-dirt accumulation rates and chemical composition, and removal efficiencies by mechanical- and vacuum-type sweepers, New Bedford, Massachusetts, 2003-04: U.S. Geological Survey Scientific Investigations Report 2005$5184,27 \mathrm{p}$.

Burge, I.J., Poiger, T., Müller. M.D., and Buser, H., 2003, Caffeine, an anthropogenic marker for wastewater contamination of surface waters: Environmental Science \& Technology, v. 37, p. 691-700.

Canadian Council of Ministers of the Environment, 2011, Summary of existing Canadian environmental quality guidelines summary table, accessed June 7, 2011, at http:// st-ts.ccme.ca/.

Childress, C.J.O., Foreman, W.T., Connor, B.F., and Maloney, T.J., 1999, New reporting procedures based on longterm method detection levels and some considerations for interpretations of water-quality data provided by the U.S. Geological Survey National Water Quality Laboratory: U.S. Geological Survey Open-File Report 99-193, p. 19.

Chow, V.-T., Maidment, D.R., and Mays, L.W., 1988, Applied hydrology: New York, McGraw-Hill Book Company, 572 p.

Church, P.E., Armstrong, D.S., Granato, G.E., Stone, V.J., Smith, K.P., and Provencher, P.L., 1996, Effectiveness of highway-drainage systems in preventing contamination of ground water by road salt, Route 25 , southeastern Massachusetts - Description of study area, data collection programs, and methodology: U.S. Geological Survey OpenFile Report, 96-317, 72 p.

City of Cambridge, 2011, Surface water supply protection plan, accessed September 16, 2011, at http://www2. cambridgema.gov/CWD/watershed.cfm.

Cohen, J., 1988, Statistical power and analysis for the behavioral sciences ( $2 \mathrm{~d}$ ed.): Hillsdale, N.J., Lawrence Erlbaum Associates, Inc., 567 p.

Commonwealth of Massachusetts, Executive Office of Energy and Environmental Affairs (MassEOEEA), Department of Environmental Protection, Office of Research and Standards, 2009, Standards and guidelines for contaminants in Massachusetts drinking waters, accessed February 16, 2010, at http://www.mass.gov/dep/water/dwstand.pdf.
Commonwealth of Massachusetts, Executive Office of Energy and Environmental Affairs, Department of Environmental Protection, Water, Wastewater \& Wetlands: Regulations \& Standards, 2007, Massachusetts surface water quality standards, accessed August 24, 2011, at http://www.mass.gov/ dep/service/regulations/314cmr04.pdf.

Commonwealth of Massachusetts, Massachusetts Highway Department, 2008, Policy for reduced salt areas in the vicinity of water supplies, accessed January 05, 2010, at http://www.mhd.state.ma.us/downloads/snowIce/saltpolicy/ salt_policy.pdf.

Extension Toxicology Network, 1993a, Pesticide information profile for Dinoseb, accessed February 08, 2010, at http:// pmep.cce.cornell.edu/profiles/extoxnet/dienochlor-glyphosate/dinoseb-ext.html.

Extension Toxicology Network, 1993b, Pesticide information profile for diuron, accessed April 05, 2006, at http://pmep. cce.cornell.edu/profiles/extoxnet/dienochlor-glyphosate/ diuron-ext.html.

Extension Toxicology Network, 1993c, Pesticide information profile for MCPA, accessed April 05, 2006, at http://pmep. cce.cornell.edu/profiles/extoxnet/haloxyfop-methylparathion/mcpa-ext.html.

Extension Toxicology Network, 1993d, Pesticide information profile for metalaxyl, accessed April 05, 2006, at http:// pmep.cce.cornell.edu/profiles/extoxnet/haloxyfop-methylparathion/metalaxyl-ext.html.

Extension Toxicology Network, 1993e, Pesticide information profile for propoxur, accessed April 05, 2006, at http:// pmep.cce.cornell.edu/profiles/extoxnet/metiram-propoxur/ propoxur-ext.html.

Extension Toxicology Network, 1993f, Pesticide information profile for Tebuthiuron, accessed February 08, 2010, at http://pmep.cce.cornell.edu/profiles/extoxnet/pyrethrinsziram/tebuthiuron-ext.html.

Extension Toxicology Network, 1994, Pesticide information profile for Sulfometuron-methyl, accessed February 08, 2010, at http://pmep.cce.cornell.edu/profiles/extoxnet/ pyrethrins-ziram/sulfometuron-methyl-ext.html.

Extension Toxicology Network, 1996a, Pesticide information profile for Benomyl, accessed February 08, 2010, at http:// extoxnet.orst.edu/pips/benomyl.htm.

Extension Toxicology Network, 1996b, Pesticide information profile for carbaryl, accessed September 13, 2011, at http:// extoxnet.orst.edu/pips/carbaryl.htm.

Extension Toxicology Network, 1997, Pesticide information profile for propiconazole, accessed April 05, 2006, at http:// pmep.cce.cornell.edu/profiles/extoxnet/metiram-propoxur/ propiconazole-ext.html. 
Extension Toxicology Network, 2005, Pesticide information profile for imidacloprid, accessed April 05, 2006, at http://pmep.cce.cornell.edu/profiles/extoxnet/haloxyfopmethylparathion/imidacloprid-ext.html.

Fishel, F.M., 2011, Pesticide use trends in the U. S.: pesticides for home and garden uses, accessed June 10, 2011, at http:// edis.ifas.ufl.edu.

Fishman, M.J., ed., 1993, Methods of analysis by the U.S. Geological Survey National Water Quality LaboratoryDetermination of inorganic and organic constituents in water and fluvial sediments: U.S. Geological Survey OpenFile Report 93-125, 217 p.

Fishman, M.J., and Friedman, L.C., 1989, Methods for determination of inorganic substances in water and fluvial sediments: U.S. Geological Survey Techniques of WaterResources Investigations, book 5, chap. A1, 545 p.

Furlong, E.T., Anderson, B.D., Werner, S.L., Soliven, P.P., Coffey, L.J., and Burkhardt, M.R., 2001, Methods of analysis by the U.S. Geological Survey National Water Quality Laboratory-Determination of pesticides in water by graphitized carbon-based solid-phase extraction and high-performance liquid chromatography/mass spectrometry: U.S. Geological Survey Water-Resources Investigations Report 01-4134, 73 p.

Garbarino, J.R., Kanagy, L.K., and Cree, M.E., 2006, Determination of elements in natural-water, biota, sediment and soil samples using collision/reaction cell inductively coupled plasma-mass spectrometry: U.S. Geological Survey Techniques and Methods, book 5, sec. B, chap. 1, 88 p.

Geotechnical Engineers, Inc., 1985, Hobbs Brook Reservoir sodium chloride study: Geotechnical Engineers, Inc. [variously paged].

Gilliom and others, 2006, The quality of our Nation's watersPesticides in the Nation's streams and ground water, 1992-2001: U.S. Geological Survey Circular 1291, 172 p.

Granato, G.E., 2007, Stochastic Empirical Loading and Dilution Model (SELDM), accessed April, 16, 2009, at http:// ma.water.usgs.gov/FHWA/SELDM.htm.

Granato, G.E., and Smith, K.P., 1999, Estimating concentrations of road-salt constituents in highway-runoff from measurements of specific conductance: U.S. Geological Survey Water-Resources Investigations Report 99-4077, 22 p.

Harmel, R. D., Cooper, R. J., Slade, R. M., Haney, R. L., and Arnold J. G., 2006, Cumulative uncertainty in measured streamflow and water quality data for small watersheds: Transactions of the American Society of Agricultural and Biological Engineers, v. 49, no. 3, p. 689-701.
Harned, H.S., and Owen, B.B., 1958, The physical chemistry of electrolytic solutions (3d ed.): New York, Reinhold Publishing Corporation, $803 \mathrm{p}$.

Helsel, D.R., 2005, Nondetects and data analysis: statistics for censored environmental data: New York, John Wiley and Sons, $250 \mathrm{p}$.

Helsel, D.R., Cohn, T.A., and Harrington, John, 1988, Program to estimate summary statistics for data with multiple detection limits for Microsoft Windows (MDLWIN), accessed July 22, 2011, at http://www.practicalstats.com.

Helsel, D.R., and Hirsch, R.M., 1992, Statistical methods in water resources: New York, Elsevier, Studies in Environmental Science 49, $522 \mathrm{p}$.

Helsel D.R., and Hirsch, R.M., 2002, Statistical methods in water resources-Hydrologic analysis and interpretation: Techniques of Water-Resources Investigations of the U.S. Geological Survey, book 4, chap. A3, 510 p.

Hem, J.D., 1982, Conductance-A collective measure of dissolved ions, in Minear, R.A., and Keith, L.A., eds., Water Analysis, v. 1, Inorganic species, Part 1: New York, Academic Press, p. 137-161.

Hem, J.D., 1992, Study and interpretation of the chemical characteristics of natural water ( $3 \mathrm{~d}$ ed): U.S. Geological Survey Water-Supply Paper 2254, 263 p.

Hirsch, R.M., 1982, A comparison of four streamflow record extension techniques: Water Resources Research, v. 18, no. 4, p. 1081-1088.

Hirsch, R.M., and Gilroy, E.J., 1984, Methods of fitting a straight line to data-Examples in water resources: Water Resources Bulletin, v. 20, no. 5, p. 705-711.

Hornsby, A.G., Wauchope, R.D., and Herner, A.E., 1996, Pesticide properties in the environment: New York, SpringerVerlag, $227 \mathrm{p}$.

Kegley, S.E., Hill, B.R., Orme S., and Choi A.H., 2010, PAN pesticide database, Pesticide Action Network, North America, accessed on September 14, 2011, at http:www. pesticideinfo.org.

Kennedy, E.J., 1983, Computation of continuous records of streamflow: U.S. Geological Survey Techniques of WaterResources Investigations, book 3, chap. A13, 52 p.

Lawrence, S.J., and LaFontaine, J.H., 2010, Occurrence of organic wastewater-indicator compounds in urban streams of the Atlanta area, Georgia, 2003-2006: U.S. Geological Survey Scientific Investigations Report 2010-5209, 113 p. 
MassGIS, 2002, MassGIS Datalayers Ortho imagery, accessed February 29, 2010, at http://www.mass.gov/anf/researchand-tech/it-serv-and-support/application-serv/office-ofgeographic-information-massgis/datalayers/layerlist.html.

MassGIS, 2005, MassGIS Datalayers Ortho Imagery, accessed February 29, 2010, at http://www.mass.gov/anf/researchand-tech/it-serv-and-support/application-serv/office-ofgeographic-information-massgis/datalayers/layerlist.html.

Matsubayashi, U., Velasquez, G.T., Takagi, F., 1993, Hydrograph separation and flow analysis by specific electrical conductance of water: Journal of Hydrology, v. 152, p. 179-199.

Maze, T.H., Albrecht, C., Kroeger, D., and Wiegand, J., 2007, Performance measures for snow and ice control operations: National Cooperative Highway Research Program, Transportation research board of the national academies document 136, accessed October 4, 2011, at http://onlinepubs. trb.org/onlinepubs/nchrp/nchrp_w136.pdf.

Michigan Department of Natural Resources Wildlife Division, 2010, Weekly Winter Severity Index report, accessed October 4, 2011, at http://www.michigan.gov/documents/ dnr/Weekly_WSI_Report_209953_7.pdf.

Millar, C.E., and Turk, L.M., 1949, Fundamentals of soil science: New York, John Wiley \& Sons, Inc., 462 p.

Miller, R.L., Bradford, W.L., and Peters, N.E., 1988, Specific conductance: theoretical considerations and application to analytical quality control: U.S. Geological Survey WaterSupply Paper 2311, 16 p.

Mullaney, J.R., Lorenz, D.L., Arntson, A.D., 2009, Chloride in groundwater and surface water in areas underlain by the glacial aquifer system, northern United States: U.S. Geological Survey Scientific Investigations Report 2009-5086, $41 \mathrm{p}$.

National Atmospheric Deposition Program, NADP/NTN monitoring location MA13, 2008, 2006 annual \& seasonal data summary for Site MA13, accessed August 26, 2007, at http://nadp.sws.uiuc.edu/sites/siteinfo. asp?net $=$ NTN\&id=MA13.

National Pesticide Information Center, 2010, Imidaclorprid technical fact sheet, accessed September 14, 2011, at http:// npic.orst.edu/factsheets/imidacloprid.pdf.

National Weather Service, 2011, Monthly snowfall totals for Boston Weather Service Forecast Office Airport, accessed February 22, 2011, at http://www.erh.noaa.gov/box/climate/ bossnw.shtml.
Patton, C.J., and Kryskalla, J.R., 2003, Methods of analysis by the U.S. Geological Survey National Water Quality Laboratory-Evaluation of alkaline persulfate digestion as an alternative to Kjeldahl digestion for determination of total and dissolved nitrogen and phosphorus in water: U.S. Geological Survey Water-Resources Investigations Report 03-4174, $33 \mathrm{p}$.

Pellerin, B.A., Wollheim,W.M., Feng X., and Vörösmarty, C.J., 2007, The application of electrical conductivity as a tracer for hydrograph separation in urban catchments: Hydrological Processes, v. 22, no. 12, p. 1810-1818.

Pilgrim, D.H., Huff, D.D., and Steele, T.D., 1979, Use of specific conductance and contact time relations for separating flow components in storm runoff: Water Resource Research, v. 15, p. 329-339.

Pinder, G.F., and Jones, J.F., 1969, Determination of the groundwater component of peak discharge from chemistry of total runoff: Water Resources Research, v. 5, p. 438-445.

Racke, K. D., 1993, Urban pest control scenarios and chemicals in Pesticides in urban environments: Fate and significance, in Racke, K.D., and Leslie, A.R., eds., ACS Symposium Series 522, American Chemical Society, Washington, D.C., p. $2-9$.

Radtke, D.B., Davis, J.V., and Wilde, F.D., eds., 2005, Specific electrical conductance (Ver. 1.2): U.S. Geological Survey Techniques of Water-Resources Investigations, book 9 , chap. A6, section 6.3, revised 2005.

Rantz, S.E., and others, 1982, Measurement and computation of streamflow-Volume 1. Measurement of stage and discharge: U.S. Geological Survey Water-Supply Paper 2175, $284 \mathrm{p}$.

Sando, S.K., Furlong, E.T., Gray, J.L., Meyer, M.T., and Bartholomay, R.C., 2005, Occurrence of organic wastewater compounds in wastewater effluent and the Big Sioux River in the Upper Big Sioux River Basin, South Dakota, 2003-2004: U.S. Geological Survey Scientific Investigations Report 2005-5249, 108 p.

Seiler, R.L., Zaugg, S.D., Thomas, J.M., and Howcroft D.L., 1999, Caffeine and pharmaceuticals as indicators of waste water contamination in wells: Ground Water, v. 37 no. 3, p. 405-410.

Shumway, R.H., Azari, R.S., Kayhanian, M., 2002, Statistical approaches to estimating mean water quality concentrations with detection limits: Environmental Science and Technology, v. 36, no. 15 , p. 3345-3353. 
Smith, K.P., 2005, Hydrologic, water-quality, bed-sediment, soil-chemistry, and statistical summaries of data for the Cambridge, Massachusetts, drinking-water source area, water year 2004: U.S. Geological Survey Open-File Report 2005-1383, $110 \mathrm{p}$.

Smith, K.P., 2007, Hydrologic, water-quality, and meteorological data for the Cambridge, Massachusetts, drinkingwater source area, water year 2005: U.S. Geological Survey Open-File Report 2007-1049, 119 p.

Smith, K.P., 2008, Hydrologic, water-quality, and meteorological data for the Cambridge, Massachusetts, drinkingwater source area, water year 2006: U.S. Geological Survey Open-File Report 2008-1175, 165 p.

Smith, K.P., 2011, Hydrologic, water-quality, and meteorological data for the Cambridge, Massachusetts, drinking-water source area, water year 2007-08: U.S. Geological Survey Open-File Report 2011-1077, 107 p.

Smith, K.P., and Breault, R.F., 2011, Streamflow, water quality, and constituent loads and yields, Scituate Reservoir drainage area, Rhode Island, water year 2010: U.S. Geological Survey Open-File Report 2011-1076, 26 p. (Also available at http://pubs.usgs.gov/of/2011/1076.)

Smith, K.P., and Granato, G.E., 2010, Quality of stormwater runoff discharged from Massachusetts highways, 2005-07: U.S. Geological Survey Scientific Investigations Report 2009-5269, 198 p., with CD-R. (Also available at http:// pubs.usgs.gov/sir/2009/5269/.)

Socolow, R.S., Comeau, L.Y., Zanca, J.L., and Ramsbey, L.R., 1999, Water-resources data for Massachusetts and Rhode Island, water year 1998: U.S. Geological Survey Water-Data Report MA-RI-98-1, 438 p.

Socolow, R.S., Girouard, G.G., and Ramsbey, L.R., 2003, Water-resources data for Massachusetts and Rhode Island, water year 2002: U.S. Geological Survey Water-Data Report MA-RI-02-1, $339 \mathrm{p}$.

Socolow, R.S., Leighton, J.F., Whitley, J.F., and Ventetuolo, D.J., 2002, Water-resources data for Massachusetts and Rhode Island, water year 2001: U.S. Geological Survey Water-Data Report MA-RI-01-1, 307 p.

Socolow, R.S., Whitley, J.S., Murino, D., Jr., and Ramsbey, L.R., 2001, Water-resources data for Massachusetts and Rhode Island, water year 2000: U.S. Geological Survey Water-Data Report MA-RI-00-1, 459 p.

Socolow, R.S., Zanca, J.L., Driskell, T.R., and Ramsbey, L.R., 2004, Water-resources data for Massachusetts and Rhode Island, water year 2003: U.S. Geological Survey Water-Data Report MA-RI-03-1, 368 p.
Socolow, R.S., Zanca, J.L., Murino, D., Jr., and Ramsbey, L.R., 2000, Water-resources data for Massachusetts and Rhode Island, water year 1999: U.S. Geological Survey Water-Data Report MA-RI-99-1, 401 p.

U.S. Environmental Protection Agency, 1994, RED FACTS Metalaxyl, accessed April 05, 2006, at http://www.epa.gov/ oppsrrd1/REDs/factsheets/0081fact.pdf.

U.S. Environmental Protection Agency, 1996, RED FACTS Norflurazon, accessed April 05, 2006, at http://www.epa. gov/oppsrrd1/REDs/factsheets/0229fact.pdf.

U.S. Environmental Protection Agency, 2000, Ambient water quality criteria recommendations, information supporting the development of state and tribal nutrient criteria, rivers and streams in nutrient ecoregion XIV: Washington, D.C., U.S. Environmental Protection Agency, Office of Water, December 2000, EPA 822-B-00-022 [variously paginated].

U.S. Environmental Protection Agency, 2001, Benomyl RED Facts: Benomyl fact sheet, EPA-738-F-02-001.

U.S. Environmental Protection Agency, 2003, Northern District of California Consent Decree-2nd Annual Report, accessed September 15, 2011, at http://www.epa.gov/ oppsrrd1/reregistration/nrdc-report2.htm\#benomyl.

U.S. Environmental Protection Agency, 2004a, Carbaryl IRED facts, accessed April 05, 2006, at http://www.epa.gov/ oppsrrd1/REDs/factsheets/carbaryl_factsheet.pdf.

U.S. Environmental Protection Agency, 2004b, RED FACTS MCPA, accessed April 05, 2006, at http://www.epa.gov/ oppsrrd1/REDs/factsheets/mcpa_red_fs.pdf.

U.S. Environmental Protection Agency, 2005, Environmental Protection Agency ECOTOX database, accessed September 12, 2011, at http://cfpub.epa.gov/ecotox/.

U.S. Environmental Protection Agency, 2006a, Consumer fact sheet on 2,4-D, accessed April 05, 2006, at http://www.epa. gov/safewater/contaminants/dw_contamfs/24-d.html.

U.S. Environmental Protection Agency, 2006b, Consumer Factsheet on: OXAMYL (VYDATE), accessed August 28, 2007, at http://www.epa.gov/safewater/contaminants/ dw_contamfs/oxamyl.html

U.S. Environmental Protection Agency, 2007, List of national secondary drinking water regulations, accessed September 24, 2007, at http://www.epa.gov/safewater/contaminants/ index.html\#sec.

U.S. Environmental Protection Agency, 2009a, National recommended water quality criteria, accessed November 17 , 2009, at http://www.epa.gov/waterscience/criteria/wqctable/ nrwqc-2009.pdf. 
U.S. Environmental Protection Agency, 2009b, Sodium in drinking water, accessed August 31, 2011, at http://water. epa.gov/scitech/drinkingwater/dws/ccl/sodium.cfm.

U.S. Geological Survey, 1999, The quality of our nation's waters-Nutrients and pesticides: U.S. Geological Survey Circular 1225, $82 \mathrm{p}$.

U.S. Geological Survey, 2001, National Water Information System data available on the World Wide Web (Water Data for the Nation), accessed June 10, 2011, at http://waterdata. usgs.gov/nwis/.

U.S. Geological Survey, 2009, Water-resources data for the United States, water year 2008: U.S. Geological Survey Water-Data Report WDR-US-2007, accessed April 1, 2008, and January 21, 2010, at http://wdr.water.usgs.gov/.

U. S. National Library of Medicine, Toxicology Data Network, 2010, Siduron, accessed September 14, 2011, at http://toxnet.nlm.nih.gov/cgi-bin/sis/search/a?dbs+hsdb:@ term+@DOCNO+1764.

Vogue, P.A., Kerle, E.A., and Jenkins, J.J., 1994, National Pesticide Information Center, OSU Extension Pesticide Properties Database, accessed September 14, 2011, at http:// npic.orst.edu/ingred/ppdmove.htm.

Wagner, R.J., Boulger, R.W., Jr., Oblinger, C.J., and Smith, B.A., 2006a, Guidelines and standard procedures for continuous water-quality monitors-Station operation, record computation, and data reporting: U.S. Geological Survey Techniques and Methods 1-D3, 51 p. +8 attachments, accessed April 10, 2006, at http://pubs.water.usgs.gov/ tm1d3.

Wagner, R.J., Frans, L.M., and Huffman, R.L., 2006b, Occurrence, distribution, and transport of pesticides in agricultural irrigation return flow from four drainage basins in the Columbia Basin Project, Washington, 2002-2004, and comparison with historical data: U.S. Geological Survey Scientific Investigations Report 2006-5005, 54 p.

Waldron, M.C., and Bent, G.C., 2001, Factors affecting reservoir and stream-water quality in the Cambridge, Massachusetts, drinking-water source area and implications for source-water protection: U.S. Geological Survey WaterResources Investigations Report 00-4262, 89 p.

Wilde, F.D., Busenberg, Eurybiades, and Radtke, D.B., eds, 2006, National field manual for the collection of water-quality data, Field measurements, pH (v.1.3): U.S. Geological Survey Techniques of Water-Resources Investigation, book 9, chap. A6, section 6.4, revised 2006.
Wilde, F.D., Radtke, D.B., Gibs, Jacob, and Iwatsubo, R.T., eds., September 1999, Collection of water samples: U.S. Geological Survey Techniques of Water-Resources Investigations, book 9, chap. A4, accessed November 2, 2006, at http://pubs.water.usgs.gov/twri9A4/.

Yu, Z., and Schwartz, W., 1999, Automated calibration applied to watershed-scale flow simulations: Hydrological Processes, v. $13,19 \mathrm{p}$.

Zaugg, S.D., Smith, S.G., Schroeder, M.P., Barber, L.B., and Burkhardt, M.R., 2007, Methods of analysis by the U.S. Geological Survey National Water Quality LaboratoryDetermination of wastewater compounds by polystyrenedivinylbenzene solid-phase extraction and capillary-column gas chromatography/mass spectrometry: U.S. Geological Survey Water-Resources Investigations Report 01-4186, $37 \mathrm{p}$. 
THIS PAGE INTENTIONALLY LEFT BLANK 
Prepared by the Pembroke Publishing Service Center. For more information concerning this report, contact:

\section{Office Chief}

U.S. Geological Survey New England Water Science Center Massachusetts-Rhode Island Office 10 Bearfoot Road

Northborough, MA 01532

dc_ma@usgs.gov

or visit our Web site at: http://ma.water.usgs.gov 
